Boise State University

ScholarWorks

$5-2017$

Bridging the Gap Between the Foreland and Hinterland II:

Geochronology and Tectonic Setting of Ordovician Magmatism and Basin Formation on the Laurentian Margin of New England and Newfoundland

\author{
Francis A. Macdonald \\ Harvard University \\ Paul M. Karabinos \\ Williams College \\ James L. Crowley \\ Boise State University \\ Eben B. Hodgin \\ Harvard University \\ Peter W. Crockford \\ McGill University
}

See next page for additional authors

This document was originally published in the American Journal of Science by HighWire Press. Copyright restrictions may apply. doi: 10.2475/05.2017.02 


\section{Authors}

Francis A. Macdonald, Paul M. Karabinos, James L. Crowley, Eben B. Hodgin, Peter W. Crockford, and John W. Delano 
[American Journal of Science, Vol. 317, May, 2017, P. 555-596, DOI 10.2475/05.2017.02]

\title{
BRIDGING THE GAP BETWEEN THE FORELAND AND HINTERLAND II: GEOCHRONOLOGY AND TECTONIC SETTING OF ORDOVICIAN MAGMATISM AND BASIN FORMATION ON THE LAURENTIAN MARGIN OF NEW ENGLAND AND NEWFOUNDLAND
}

\author{
FRANCIS A. MACDONALD*, ${ }^{*}$, PAUL M. KARABINOS**, JAMES L. CROWLEY***, \\ EBEN B. HODGIN*, PETER W. CROCKFORD ${ }^{\S}$, and JOHN W. DELANO ${ }^{\S \S}$
}

\begin{abstract}
Ordovician strata of the Mohawk Valley and Taconic allochthon of New York and the Humber margin of Newfoundland record multiple magmatic and basin-forming episodes associated with the Taconic orogeny. Here we present new $\mathrm{U}-\mathrm{Pb}$ zircon geochronology and whole rock geochemistry and neodymium isotopes from Early Paleozoic volcanic ashes and siliciclastic units on the northern Appalachian margin of Laurentia. Volcanic ashes in the Table Point Formation of Newfoundland and the Indian River Formation of the Taconic allochthon in New York yield dates between $466.16 \pm 0.12$ and $464.20 \pm 0.13 \mathrm{Ma}$. Red, bioturbated slate of the Indian River Formation record a shift to more juvenile neodymium isotope values suggesting sedimentary contributions from the Taconic arc-system by 466 Ma. Eight ashes within the Trenton Group in the Mohawk Valley were dated between $452.63 \pm 0.06$ and $450.68 \pm 0.12 \mathrm{Ma}$. These ashes contain zircon with Late Ordovician magmatic rims and 1.4 to 1.0 Ga xenocrystic cores that were inherited from Grenville basement, suggesting that the parent magmas erupted through the Laurentian margin. The new geochronological and geochemical data are integrated with a subsidence model and data from the hinterland to refine the tectonic model of the Taconic orogeny. Closure of the Iapetus Ocean by 475 Ma via collision of the peri-Gondwanan Moretown terrane with hyperextended distal fragments of the Laurentian margin is not clearly manifested on the autochthon or the Taconic allochthon other than an increase in sediment accumulation. Pro-foreland basins formed during the Middle Ordovician when these terranes were obducted onto the Laurentian margin. 466 to $464 \mathrm{Ma}$ ashes on the Laurentian margin coincide with a late pulse of magmatism in both the Notre Dame arc in Newfoundland and the Shelburne Falls arc of New England that is potentially related to break-off of an east-dipping slab. Following slab reversal, by $455 \mathrm{Ma}$, the Bronson Hill arc was established on the new composite Laurentian margin. Thus, we conclude that Late Ordovician strata in the Mohawk Valley and Taconic allochthon of New York and on the Humber margin of Newfoundland were deposited in retro-foreland basins.
\end{abstract}

Key words: Taconic, Ordovician, Moretown, Foreland, geochronology, New York, Taconic allochthon, Giddings Brook slice, Newfoundland, Humber margin.

\section{INTRODUCTION}

Early Paleozoic rocks in the Appalachian Mountains of New England (fig. 1) and Newfoundland record the break-up of the supercontinent Rodinia, the opening of the Iapetus Ocean, and the closure of the Iapetus following collision with Gondwananderived terranes. The obduction of ophiolites and arc terranes and initiation of an active margin on Laurentia is recorded in the Taconic orogeny of New England, which has been extensively reviewed and discussed (for example, Bird and Dewey, 1970;

* Department of Earth and Planetary Science, Harvard University, 20 Oxford Street, Cambridge, Massachusetts 02138

** Department of Geology, Williams College, Williamstown, Massachusetts 01267

*** Department of Geosciences, Boise State University, Boise, Idaho 83725

${ }^{\S}$ Department of Earth and Planetary Science, McGill University and GEOTOP, Montréal, QC, H3A 0E8, Canada

$\$ \S$ Department of Atmospheric and Environmental Science, University at Albany, State University of New York, Albany, New York 12222

${ }^{+}$Corresponding author: fmacdon@fas.harvard.edu; Tel: (617) 496-2236; Fax: 617-495-8839 


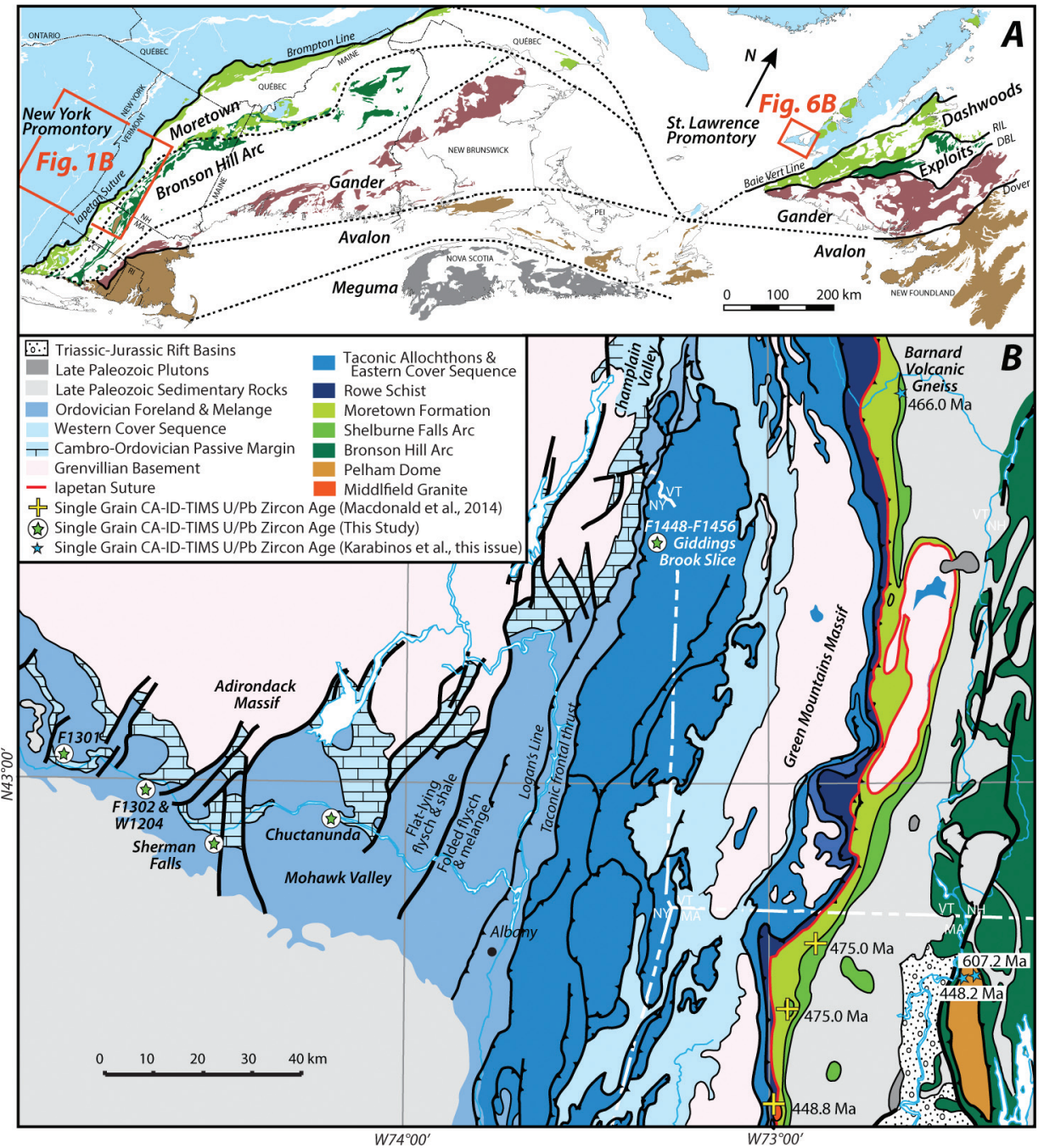

Fig. 1. (A) Tectonic map of Appalachians modified from Hibbard and others (2006), showing location of maps in figures 1B and 6A. (B) Geological map of the New England Appalachians showing location of samples, modified from Hibbard and others (2006) and Ratcliffe and others (2011). Single-grain CAIDTIMS U-Pb zircon ages from Macdonald and others (2014). Bulk TIMS and SHRIMP U-Pb zircon ages from Karabinos and others (2017) and references therein.

Rowley and Kidd, 1981; Zen, 1983; Stanley and Ratcliffe, 1985), but many of the concepts originated before precise geochronology was available to calibrate tectonic models. With new geochronological constraints, it has become increasingly apparent that Early to Middle Ordovician magmatism and metamorphism in the Taconic hinterland (Laird and others, 1984; Karabinos and others, 1998; Tremblay and others, 2011; Castonguay and others, 2012; Macdonald and others, 2014; Tremblay and Pinet, 2016) and Late Ordovician foreland deposition on the Laurentian margin (for example, Rowley and Kidd, 1981) are not coeval. Previously, these differences have been interpreted to represent diachronous development of a single pro-foreland basin (Rowley and Kidd, 1981; Bradley and Kusky, 1986; Bradley, 1989; Lavoie, 1994; 
Lehmann and others, 1995); however, this scenario would necessitate a flexural load persisting for more than 15 million years, and cannot explain subsidence patterns in the midcontinent (Coakley and Gurnis, 1995; Macdonald and others, 2014). Diachroneity of tectonic events along the margin could also be influenced by large-scale translational motion or different manifestations of tectonism between promontories and embayments; however, despite apparent differences in ages of foreland basin deposition along the margin, ages of magmatism and deformation in New England, Québec, Newfoundland, the British Isles and Norway are remarkably similar (Clift and others, 2003; Castonguay and others, 2012; van Staal and Barr, 2012; Macdonald and others, 2014; Hollocher and others, 2016; Tremblay and Pinet, 2016). An additional potential complication to linking the tectonic history of the hinterland with deposition on the Laurentian cratonic margin is that tectonic activity nucleated on transitional crust of hyper-extended margins (van Staal and others, 2013) may be difficult to detect on the craton. Moreover, defining the boundaries of potential peri-Laurentian distended terranes, including the boundary between terranes of Laurentian and Gondwanan affinity that mark the main Iapetan suture, has been extremely contentious (for example, Moench and Aleinikoff, 2003; Dorais and others, 2011; Rankin and others, 2013; Macdonald and others, 2014).

Both an orogen-wide tectonic synthesis and attempts to relate foreland basin formation and hinterland deformation have been limited by disagreements about the tectonic affinity of accreting arc fragments and the age of accretionary events. Particularly, in Newfoundland it has been suggested that the earliest terrane to accrete to the Laurentian margin, Dashwoods, consists of a Cambrian to Ordovician arc that formed on a Laurentian cratonic fragment (Waldron and van Staal, 2001). Building off the work of Williams (1979), Waldron and van Staal (2001) suggested that the Iapetan suture in Newfoundland is located east of Dashwoods along the Red Indian Line. However, the Laurentian affinity of the basement to the Dashwoods terrane has not been clearly established. Alternatively, it was recently suggested that the western-most arc terrane in New England is peri-Gondwanan (Macdonald and others, 2014), which challenges the concept of a continuous peri-Laurentian ribbon continent as a fundamental element of the Appalachian orogeny (Hibbard and others, 2006).

Here we present new, precise U-Pb chemical abrasion-isotope dilution thermal ionization mass spectrometry (CA-IDTIMS) zircon dates from ashes in Laurentian basins. We focus on the classic Ordovician sections of the Mohawk Valley and the Giddings Brook slice of the Taconic allochthon, and distinguish pro- and retroforeland basins. We compare these data to new geochronology from the Humber margin of Newfoundland. We not only date ashes in the basins, but also date detrital and xenocrystic zircon and present neodymium isotope values and whole rock geochemical data from slate to assess the age of the basement that the parent magmas erupted through and the proximity of exotic detrital sources to the Laurentian margin. These data inspire a new tectonic model that accounts for Ordovician subsidence patterns on Laurentia and provides a mechanism to initiate subduction beneath Laurentia.

STRATIGRAPHY

\section{The Paleozoic Platform Margin}

In New England, late Ediacaran to Cambrian sedimentary rocks rest on magmatic and metamorphic rocks associated with the late Mesoproterozoic to early Neoproterozoic (1250-980 Ma) Grenville orogeny (Karabinos and Aleinikoff, 1990; Rivers, 1997; Carr and others, 2000; Karabinos and others, 2008). These sedimentary strata were deposited in rift-related basins that formed during the Neoproterozoic break-up of the supercontinent Rodinia. In the northern Appalachians, Neoproterozoic plume- and 
rift-related magmatism began with the circa 615 Ma Long Range dikes (Kamo and others, 1989). The last phase of rift-related magmatism observed along the Humber margin of Newfoundland occurred between 565 and $550 \mathrm{Ma}$ and is coeval with ultramafic rocks in the Birchy Complex that are characteristic of an ocean-continent transition zone (van Staal and others, 2013). Hodych and Cox (2007) documented Laurentian plume- and rift-related magmatism in Québec between 565 to $550 \mathrm{Ma}$, which includes the voluminous $554+4 /-2$ Ma Tibbit Hill Formation (Kumarapeli and others, 1989).

Rift-related sedimentary deposits are thin or absent inboard of the Appalachian deformation front (Logan's Line, fig. 1), but locally consist of Terreneuvian to Cambrian Series 2 siliciclastic rocks of the Altona Formation and Cambrian Series 2 to Furongian conglomerate and quartz arenite of the Potsdam Formation, the latter of which was deposited near the rift-drift transition (fig. 2). On the Laurentian autochthon, in the Mohawk Valley of New York, the Potsdam Formation is overlain by carbonate of the Furongian to Middle Ordovician Beekmantown Group (Landing, 2012). These strata were deposited after the rift-drift transition, but before Middle Ordovician foreland deposits, and extend throughout Québec (Lavoie and others, 2003). The top of the Beekmantown Group is composed of the unconformity bounded Providence Island Formation, which is correlative with the Carillon Formation is southern Québec (Dix and Rodhan, 2006). In the Champlain Valley, the Beekmantown Group is unconformably overlain by the Middle to Late Ordovician Chazy Group (fig. 3A). This unconformity has been correlated with the Knox unconformity in the southern Appalachians (Mussman and Read, 1986) and the Sauk-Tippecanoe sequence boundary (Sloss, 1963), and can be extended through Québec (Lavoie and others, 2003; Dix and others, 2013) to the St. George unconformity of Newfoundland (Knight and others, 1991).

Platformal carbonate of the Chazy Group thins north and westward from $>270 \mathrm{~m}$ in the Champlain Valley of New York to $\sim 25 \mathrm{~m}$ in the Ottawa embayment of Québec and Ontario (Dix and others, 2013). Seaward reefal carbonates of the Chazy Group in the Champlain Valley grade into platform interior tide- and wave- dominated siliciclastic rocks of the Rockliffe Formation and restricted peritidal muddy carbonates of the Hog's Back Formation in the Ottawa embayment (Dix and others, 2013). In the Champlain Valley, the Chazy Group is unconformably overlain by limestone of the Sandbian Black River Group with the contact marked by $<1 \mathrm{~m}$ of arkosic sandstone (fig. 3B). The Black River Group thickens west and north into Canada where it consists of up to $75 \mathrm{~m}$ of platformal carbonate with abundant birds-eye texture and interbedded bentonite beds (Young, 1943; Brett and Baird, 2002).

In the Mohawk Valley, the Late Ordovician Trenton Group rests unconformably on the Beekmantown Group, and both the Chazy and the Black River groups are cut out by overlapping unconformities (fig. 2). The Trenton Group of New York provides a robust stratigraphic framework derived from geochemically fingerprinted K-bentonite beds, graptolite and conodont biozones, carbon isotope chemostratigraphy, and sequence stratigraphic marker beds (Mitchell and others, 1994; Brett and Baird, 2002; Metzger and others, 2014; Sell and others, 2015). In the Mohawk Valley the carbonate of the Trenton Group grades up-section and eastward into calcareous gray and black shale of the informal Utica Shale. The Utica has been divided into the Flat Creek and Indian Castle formations, which are separated by an eastward tapering carbonate wedge of the Dolgeville Formation (fig. 4).

At Canajoharie Creek (fig. 4), the Glen Falls limestone rests above the Beekmantown Group in a sharp, low-angle unconformity. The Glen Falls limestone is equivalent to the King Falls limestone to the west. The base of the Glen Falls limestone consists of a fossiliferous pebble lag deposit, composed predominantly of brachiopod fragments. 


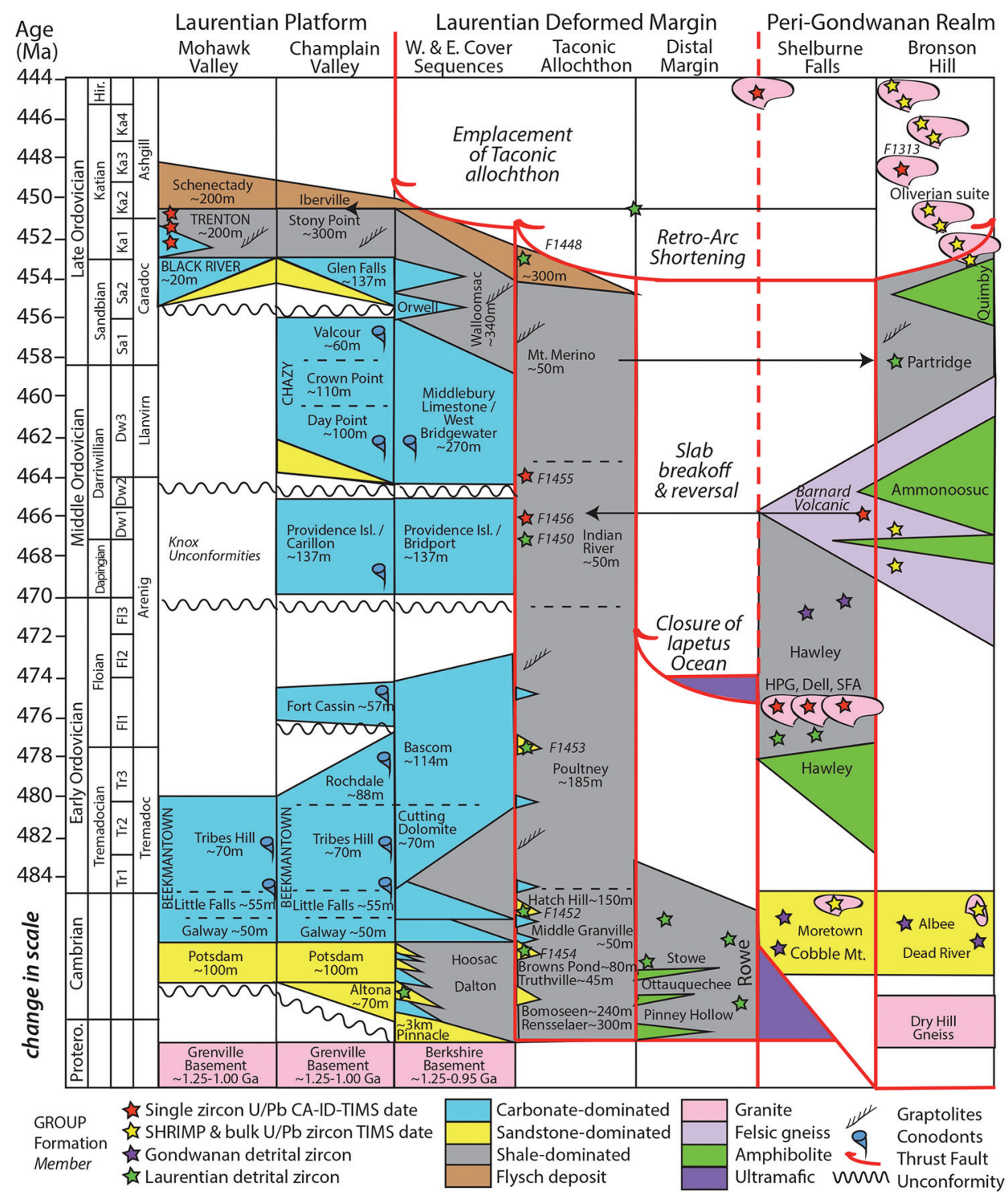

Fig. 2. Time-space diagram of Neoproterozoic to Ordovician rocks involved in the Taconic orogeny of New England. Laurentian platform stratigraphy is modified from Landing (2012). Western and Eastern cover sequences stratigraphy is modified from Karabinos (1988) and Ratcliffe and others (1999). Stratigraphy of the Giddings Brook slice of the Taconic allochthon is modified from Landing (2012) and Rowley and others (1979). Detrital zircon provenance indicators and stratigraphy of Rowe, Moretown, and Hawley belts from Macdonald and others (2014) and Karabinos and others (2017).

The overlying $\sim 5 \mathrm{~m}$ consists of bioclastic nodular limestone and grainstone that shale out to a condensed pyritiferous black mudstone marking the base of the Flat Creek Formation (fig. 4). Up-section, the Flat Creek Formation consists of black shale with graded interbeds of silty carbonate and numerous K-bentonite horizons (fig. 3C and 3D), which are white when fresh and commonly weather orange. The Flat Creek Formation is over $100 \mathrm{~m}$ thick and contains graptolites of the Katian C. americanus biozone (Goldman and others, 1994; Mitchell and others, 1994). 


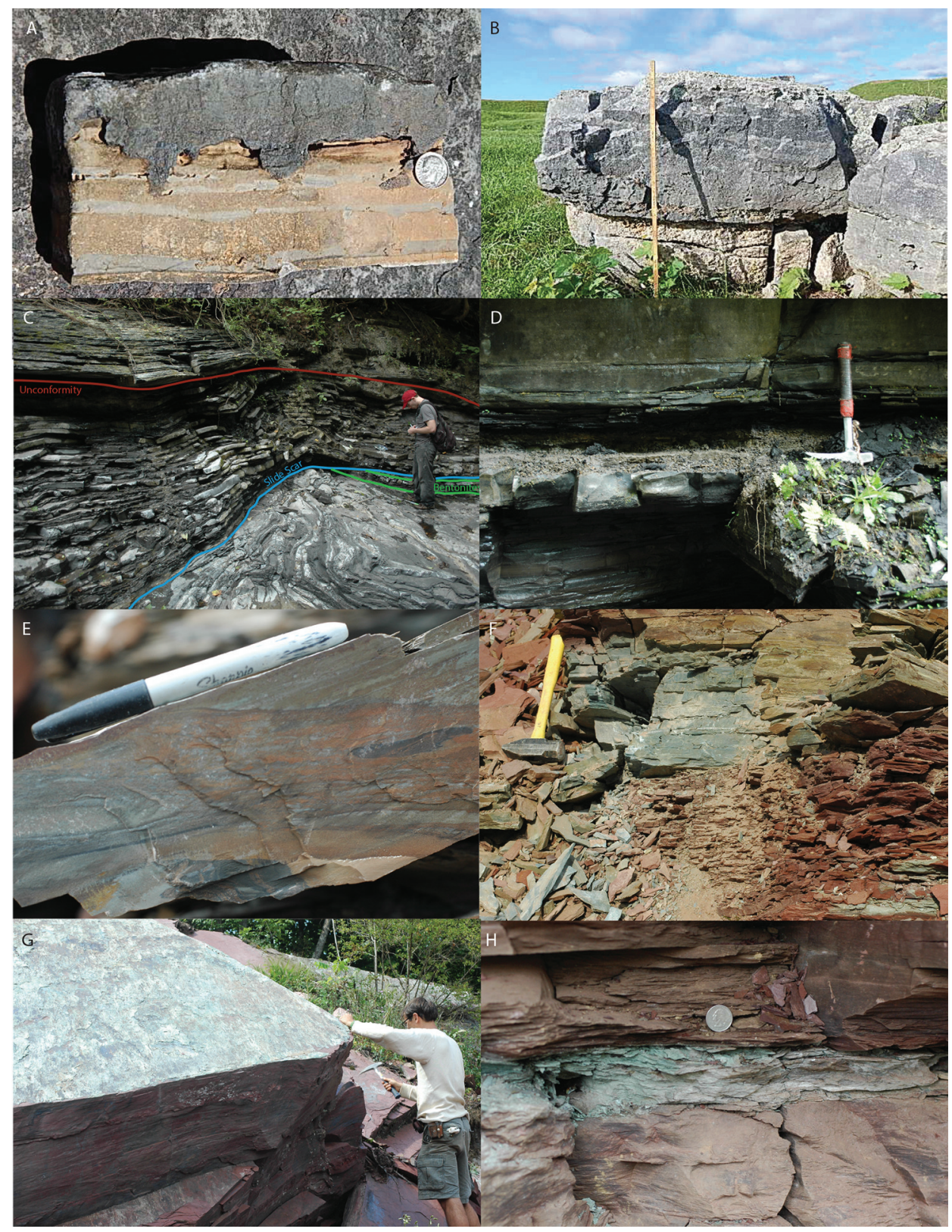

Fig. 3. Field photos of: (A) Block of the karstic unconformity at the base of the Chazy Formation on the southern point of Isle La Motte, photo by Nizhoni O'Connell; (B) Sandstone above unconformity at the base of the Black River Formation at Crown Point, New York, photo by Nizhoni O'Connell; (C) Throughway unconformity above a slide block and slump folding from Small's Bush Road. Bentonite bed at feet of the geologist was sampled (F1302-1.8) and dated at 451.6 $\pm 0.2 \mathrm{Ma}$ and correlated with the Manheim ash at Nowadaga Creek; (D) Countryman ash (F1301-7.7) at North Creek, which has abundant Grenvillian xenocrystic inheritance; (E) Debrite in Early Ordovician Poultney Formation just below the contact with the Indian River Formation near the F1450 sample location shown in figure 5B. Bedding is parallel with the frame of the picture and foliation is parallel with the orientation of the sharpie; (F) Sample F1450 volcaniclastic unit dated at $466.1 \pm 0.2 \mathrm{Ma} ;(\mathrm{G})$ Sample F1456 ash on bedding plane dated at $464.2 \pm 0.1 \mathrm{Ma}$; (H) Sample F1455 ash dated with LA-ICPMS at $\sim 465$ Ma with inheritance between $\sim 1100$ and $1500 \mathrm{Ma}$. Locations of photos $\mathrm{F}, \mathrm{G}$, and $\mathrm{H}$ are shown in figure $5 \mathrm{~B}$. 

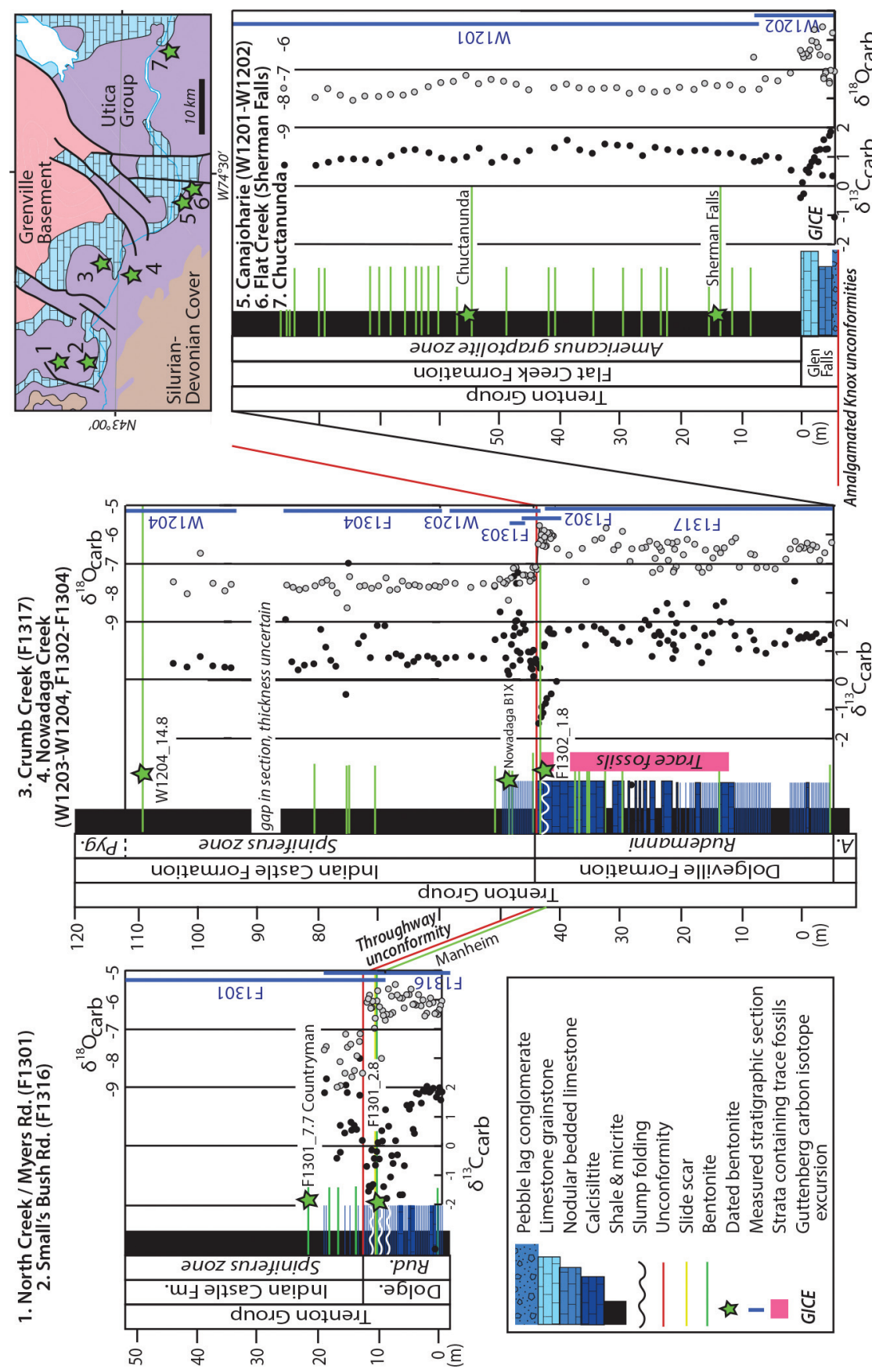
Using geochemical fingerprinting (Delano and others, 1994; Mitchell and others, 1994), K-bentonite beds in the Flat Creek Formation can be correlated from Canajoharie Creek eastward to exposures at Flat Creek and Chuctanunda Creek and westward to exposures at Nowadaga Creek and Crumb Creek (fig. 4). At Crumb Creek, the Flat Creek Formation is gradationally overlain by graded beds of carbonate of the Dolgeville Formation. The Dolgeville Formation is up to $50 \mathrm{~m}$ thick and contains graptolites of the Katian O. rudemanni biozone (Goldman and others, 1994; Mitchell and others, 1994). Graded beds are $10 \mathrm{~s}$ of $\mathrm{cm}$ to a meter thick. Some of which contain bioclastic grainstone at the base and fine upwards to calcisiltite and carbonate mudstone. Trace fossils are common within the Dolgeville Formation but absent in both the overlying and underlying formations. The shoaling upwards sequence culminates at the contact between the Dolgeville and Indian Castle formations with evidence for local syn-sedimentary normal faulting and slump folding (fig. 3C) that marks the Throughway Unconformity (Jacobi and Mitchell, 2002).

The Throughway Unconformity is overlain by shale with thin interbeds of calcisiltite of the Indian Castle Formation. Calcisilitite beds become less common up-section. The Indian Castle Formation is over $60 \mathrm{~m}$ thick and contains graptolites of the Katian C. spiniferous biozone (Goldman and others, 1994; Mitchell and others, 1994). The uppermost Indian Castle Formation also contains graptolites of the Katian C. pygmeus biozone (Goldman and others, 1994).

The Indian Castle Formation is overlain by flysch deposits of the Frankfort and Schenectady formations (fig. 4). In the Mohawk Valley, west of Schenectady, New York, where the Trenton Group is broadly flat-lying, the Frankfort Formation consists of graded beds of siliciclastic turbidites with spectacularly fluted soles. To the east, the coeval Schenectady Formation is folded, and near Albany, New York, it is a mélange with broken beds (fig. 1). Just east of the Hudson River, the Taconic frontal thrust separates the Ordovician forelands from thrust slices of the Taconic allochthon. Although the Taconic frontal thrust was active during the Late Ordovician, it was likely reactivated in the Silurian and Devonian (Bosworth and others, 1988; Karabinos and others, 2008).

\section{The Early Paleozoic Slope to Distal Margin}

Laurentian Paleozoic slope and distal margin deposits flank structural inliers of Grenvillian basement in Eastern and Western cover sequences (Karabinos, 1988), the Taconic allochthon (Zen, 1967; Rowley and Kidd, 1981), and the Rowe belt (Macdonald and others, 2014). Although circa 1350 to 1000 Ma Grenville basement dominates the Berkshires and Green Mountain massifs in Vermont and Massachusetts, slightly younger, 965 to $945 \mathrm{Ma}$ post-orogenic magmatism has been documented in the southern end of the Green Mountain massif (Karabinos and Aleinikoff, 1990; Ratcliffe and others, 1991; Karabinos and others, 2008).

Ediacaran and Early Cambrian immature siliciclastic units are present in the Eastern cover sequence and Taconic allochthon that can be attributed to rifting and local fault controlled deposition. Rift-related rocks of the Western cover sequence include conglomerate of the Dalton Formation in the Berkshire massif of western Massachusetts and the Pinnacle Formation, Forrestdale Marble and Moosalamoo Phyllite of the Green Mountain massif. The rift-drift transition is bracketed by circa 550 Ma volcanic rocks and Cambrian Series 2 (circa $520 \mathrm{Ma}$ ) mature quartzite deposits of the Cheshire Quartzite (fig. 2). East of the Green Mountain massif, in the Eastern cover seqeuence, rift-related rocks include the Tyson and Hoosac formations (Karabinos, 1988). Cambro-Ordovician platformal rocks of the Beekmantown Group can be correlated with mixed carbonate and siliciclastic and carbonate units of the Western cover sequence in western Massachusetts (fig. 2). These are overlain by Middle to Late Ordovician shale and carbonate of the Walloomsac Formation that are in part 


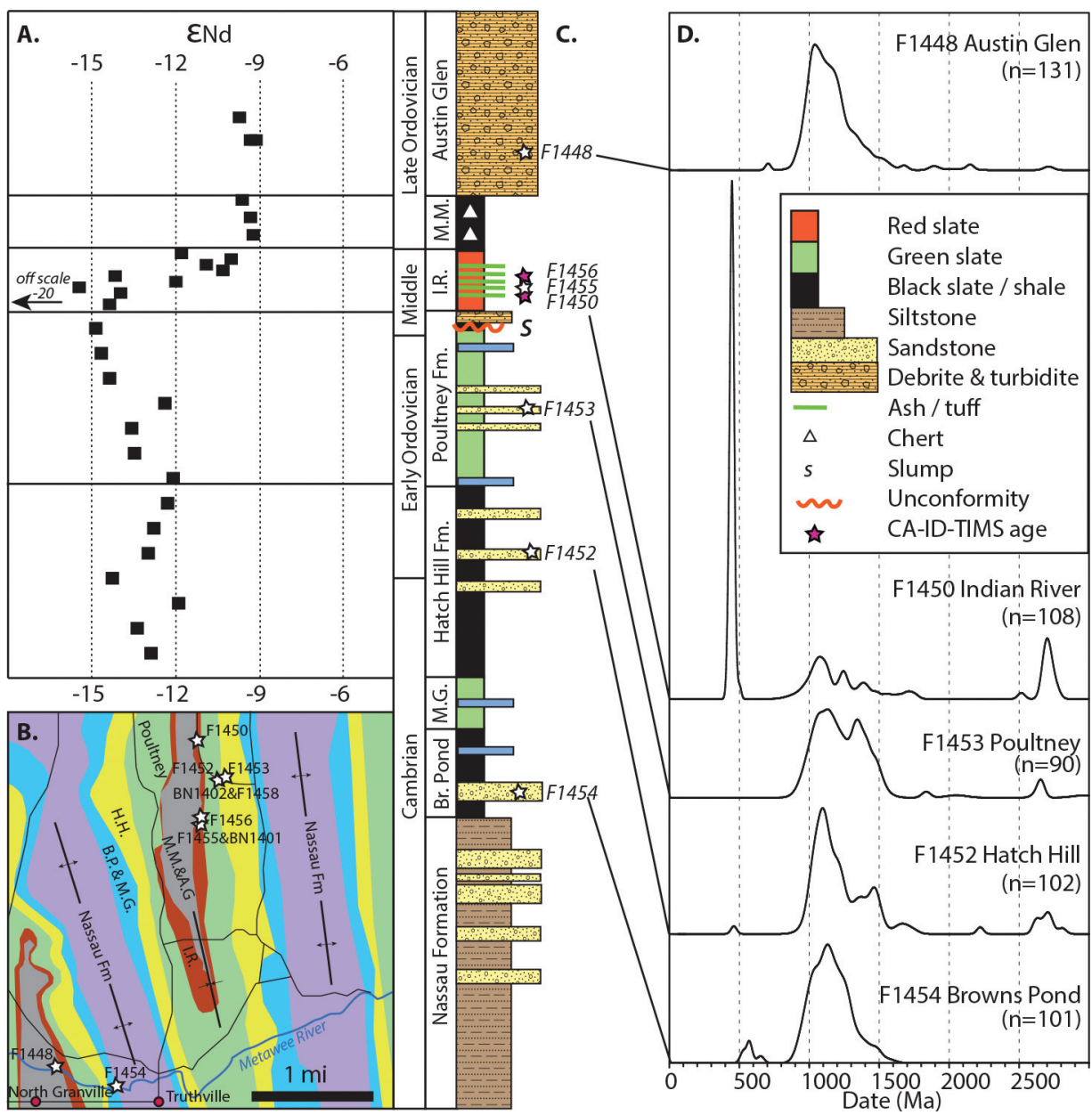

Fig. 5. (A) Neodymium isotopes from Paleozoic slates on the Giddings Brook slice. (B) Location map modified from Jacobi (ms, 1977) showing positions of samples. B.P. = Browns Pond Formation, M.G. = Middle Granville Formation, H.H. = Hatch Hill Formation, I.R = Indian River Formation, M.M. = Mount Merino Formation, A.G. = Austin Glen Formation. (C) Paleozoic Stratigraphy of the Giddings Brook slice showing the stratigraphic position of geochronology samples, modified from Landing (2012) and Rowley and others (1979). (D) Detrital zircon geochronology of sandstone units on the Giddings Brook slice. Geochronological data is provided in the supplementary materials table S1, http://earth. geology.yale.edu/ ajs/SupplementaryData/2017/Macdonald.

correlative with the Middlebury Limestone on the west flank of the Green Mountains (Washington and Chisick, 1994), and the Melbourne and West Bridgewater formations east of the Green Mountains (Ratcliffe, and others, 1999).

Rift deposits are also present in thrust sheets of the Taconic allochthon (Zen, 1967). In the Giddings Brook thrust sheet, no basement-cover relationship is preserved. Large east-west lithostratigraphic variation is apparent, particularly across the South Poultney thrust (Zen, 1967; Rowley and others, 1979). Here we describe the thicker and more complete sections west of the South Poultney thrust. Stratigraphic thicknesses have been attenuated by deformation, and unstrained thicknesses (given here from Rowley and others, 1979; fig. 5) have been estimated at three times post-deformation thicknesses, and are used in the subsidence model below. In the 
western region, the Nassau Formation is the stratigraphically lowest preserved unit. The Nassau Formation consists of the Renssalaer, Bomoseen, and Truthville members. As much as $240 \mathrm{~m}$ of the Bomoseen Member is present in the Giddings Brook slice, but the base has not been observed. The Bomoseen Member consists of green greywacke and slate with interbedded quartz and lithic arenite that are gradationally overlain by well-cleaved mica-spangled olive gray-green slate of the $\sim 45 \mathrm{~m}$ thick Truthville Member (fig. 5). Landing (2012) suggested that the immature Ediacaran to Cambrian Renssaleer and Bomoseen members of the Nassau Formation formed during rifting and that the transition to turbiditic mudstone of the Truthville Member marked the rift-drift transition at circa $520 \mathrm{Ma}$.

The Truthville Member is sharply overlain by black slate of the Browns Pond Formation. The Browns Pond Formation is $\sim 80 \mathrm{~m}$ thick and along with black slate includes interbedded limestone, carbonate breccia interpreted as debris flows, calcareous quartz wacke, dolomitic calc-arenites, and clean quartz arenites, the latter of which has been separated as the Mud Pond Member. A Cambrian Series 2 age is inferred from the presence of Elliptocephala asaphoides fauna collected from limestone breccia in the Browns Pond Formation (Theokritoff, 1964; Rowley and others, 1979). Quartzite in the Mud Pond Member of the overlying Browns Pond Formation is correlated with the Cheshire Formation west of the Green Mountain and Berkshire massifs (fig. 2).

The Browns Pond Formation is gradationally overlain by the Middle Granville Formation (also referred to as the Mettawee slate). The Middle Granville Formation is an $\sim 50 \mathrm{~m}$ thick succession of well-cleaved buff to light purple to gray-green slate, with minor carbonate beds and redeposited carbonate clast conglomerate. Carbonate clasts in the Middle Granville Formation also contain the Cambrian Series 2 Elliptocephala asaphoides fauna (Rowley and others, 1979).

The Middle Granville Formation is sharply overlain by black pyritiferous slate and dark gray limestone with thin beds of dolomitic quartz arenite of the West Castleton Member of the Hatch Hill Formation. This unit is difficult to map across the region and varies in thickness from 0 to $20 \mathrm{~m}$ (Rowley and others, 1979). Regionally, Middle Cambrian trilobites have been reported in the West Castleton Member (Theokritoff and Thompson, Jr., 1969). In total, the Hatch Hill Formation is $\sim 150 \mathrm{~m}$ thick and consists of rusty black slate with thin dolomitic quartz arenite beds. Late Cambrian to Early Ordovician dendroid graptolites are present near the top of the Hatch Hill Formation (Theokritoff, 1964; Rowley and others, 1979).

The Hatch Hill Formation is overlain by the Poultney Formation, which consists of cleaved, dark gray to light green slate with thin interbedded limestone and silty quartzite. The Poultney Formation is $\sim 185 \mathrm{~m}$ thick and is equivalent to the Deep Kill Formation to the south and to the Levis facies of northern Vermont (Landing, 2012). Debrites are common in both the Levis facies and the uppermost Poultney Formation (fig. 3E). The Poultney Formation and equivalents contain Early Ordovician (Tremadocian and Floian) graptolites (Berry, 1962; Riva, 1974).

In the Giddings Brook slice, the Early Ordovician Poultney Formation is overlain by the Middle to Late Ordovician Indian River, Mount Merino, and Austin Glen formations (fig. 5). The Indian River Formation averages $\sim 50 \mathrm{~m}$ thick and consists predominantly of red slate, which is commonly quarried, with minor green to blue-green, and locally gray slate at the top. Locally present in the slates are red and green chert beds and thin fine-grained, poorly-sorted quartzite beds (Rowley and others, 1979) (fig. 3F). White to lime green flinty horizons, interpreted as silicified volcanic air-fall ash beds (figs. 3G-3H) are present in the middle to upper Indian River Formation. No fossils have been identified within the Indian River Formation.

The Indian River Formation is sharply overlain by $\sim 50 \mathrm{~m}$ of pyritiferous black chert and slate of the Mount Merino Formation. The N. gracilis graptolite zone 
constrains the age of the Mount Merino Formation from Darriwillian to Sandbian (Riva, 1974).

The uppermost unit preserved in the Giddings Brook slice is the Austin Glen Formation (equivalent to the Pawlett Formation), which consists of interbedded medium to dark gray, quartz-rich lithic greywacke and gray slate. The Austin Glen Formation is greater than $150 \mathrm{~m}$ thick and interpreted to represent an easterly derived deep-water turbidite flysch (Rowley and others, 1979; Rowley and Kidd, 1981).

The Taconic allochthon palinspastically restores to the Eastern cover sequence, west of the Rowe belt (Stanley and Ratcliffe, 1985; Karabinos, 1988), and the Rowe belt represents the most distal margin of Laurentia. Rift-related volcanic rocks have been described in the Rowe belt of Vermont and Massachusetts (Coish, 1997; Coish and others, 2011) and have been dated at $571 \pm 5 \mathrm{Ma}$ (Walsh and Aleinikoff, 1999). In the Rowe belt, interleaved albitic and talc schists and amphibolite of the Pinney Hollow, Stowe, and Ottaquchee formations (fig. 2) may in part represent an ocean continenttransition zone (compare to van Staal and others, 2013).

\section{The Humber Margin of Newfoundland}

The Ordovician stratigraphy of the Humber margin of Newfoundland is exquisitely exposed and has been described extensively at Port au Port Peninsula (for example, James and Stevens, 1986; Pratt and James, 1986; Knight and James, 1987; Stenzel and others, 1990; Knight and others, 1991; Cowan and James, 1993), where deeper water sections are imbricated in successive thrust sheets from southwest to northeast above the autochthonous carbonate shelf (Stevens, 1970; Waldron and van Staal, 2001). The Early Ordovician Bay of Islands ophiolite is preserved as a klippe in the structurally highest thrust sheet (fig. 6). The Bay of Islands ophiolite was generated at circa 485 Ma (Dunning and Krogh, 1985) in a supra-subduction setting above an east-dipping slab (present coordinates) associated with the Notre Dame Arc (Waldron and van Staal, 2001; van Staal and others, 2007; van Staal and Barr, 2012; Zagorevski and van Staal, 2014). Geochronology on the metamorphic sole suggests that the ophiolite was obducted onto the Laurentian margin at $469 \pm 5 \mathrm{Ma}$ (Dallmeyer and Williams, 1975), and was partially unroofed in the Middle Ordovician. This scenario is consistent with the development of the Early to Middle Ordovician St. George unconformity (Knight and others, 1991), evidence of faulting and disruption in the Table Head Group (Stenzel and others, 1990), and the presence of detrital chromite in the Middle Ordovician Mainland Sandstone (Stevens, 1970).

On Port au Port Peninsula, the Middle Ordovician Table Head and Goose Tickle groups rest above the St. George unconformity (fig. 6). At Cape Cormorant, the Table Head Group consists of up to $200 \mathrm{~m}$ of thin-bedded limestone of the Table Point Formation, which is overlain by shale with interbedded calcareous turbidites, carbonate clast conglomerate, and minor bentonite beds of the Cape Cormorant Formation (Albani and others, 2001). The Cape Cormorant Formation is overlain by the massively bedded, poorly sorted, green weathering Mainland Sandstone.

At Black Cove the Table Point Formation thins to $\sim 60 \mathrm{~m}$ and is overlain by shale with intercalated bentonites of the Black Cove Formation (Stenzel and others, 1990). The Black Cove Formation is overlain by siltstone turbidites of the American Tickle Formation, which include carbonate clast conglomerate beds of the Daniel Harbour Member (fig. 6). The American Tickle Formation is correlative with the upper portion of the Cape Cormorant Formation and the Mainland Sandstone (Stenzel and others, 1990). Further west in coastal exposures at West Bay, Ordovician carbonates are structurally overlain by chert and shale with intercalated bentonites that grade into turbidites and conglomerates with internal folds and broken beds of the Humber Arm allochthon (fig. 6). 


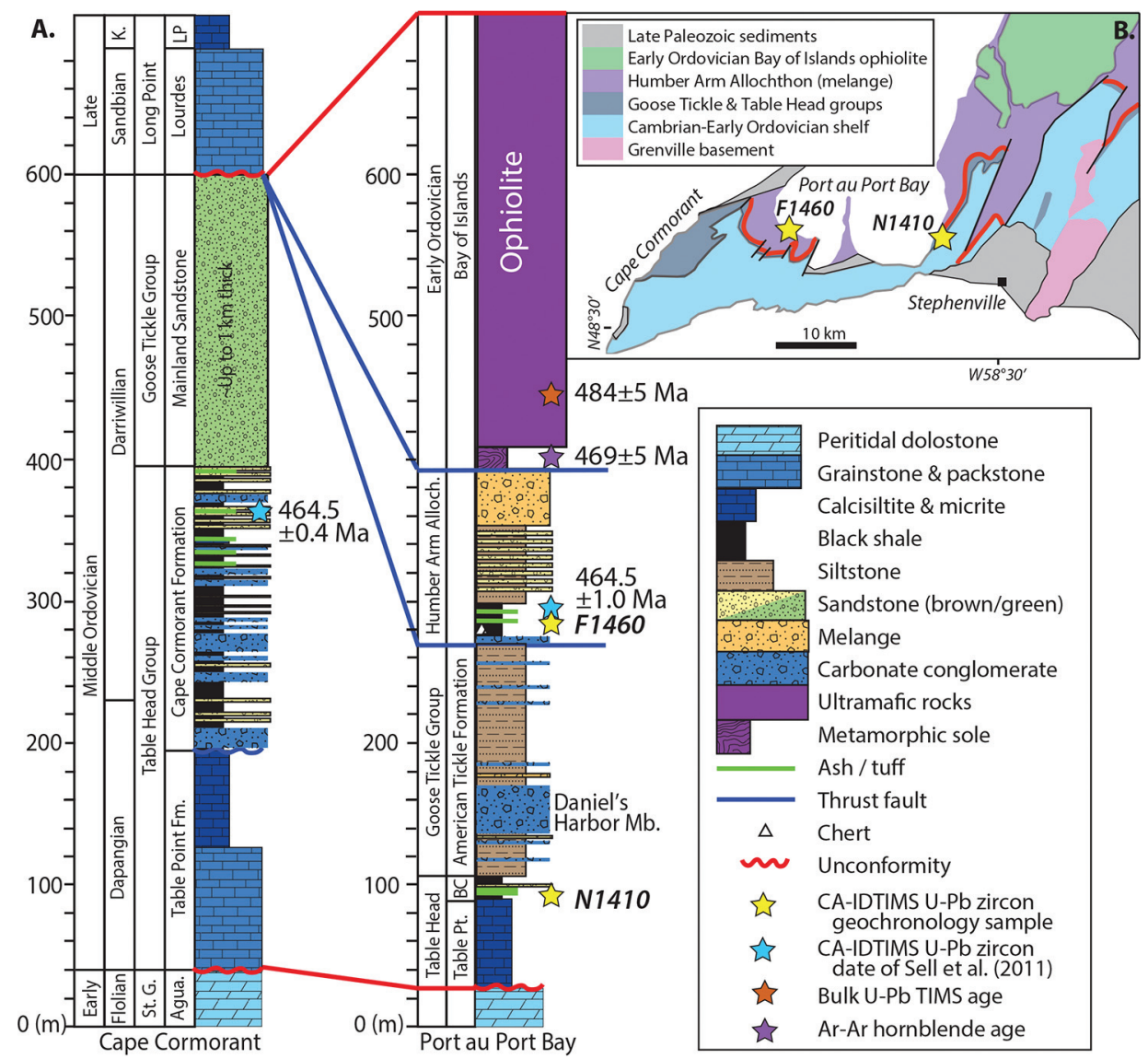

Fig. 6. (A) Middle Ordovician stratigraphy of Port au Port Peninsula modified from James and Stevens (1986) and Stenzel and others (1990) showing samples collected for geochronology. Age on ophiolite from Jenner and others (1991) and its metamorphic sole from Dallmeyer and Williams (1975). (B) Geological map modified from Howse (2004) with location of samples.

\section{Previous Geochronological Constraints on Magmatism and Metamorphism}

In the hinterland, igneous rocks have been dated between 500 and $445 \mathrm{Ma}$ (Karabinos and others, 2017). Karabinos and others (1998) first identified 475 to 470 Ma magmatism in the Shelburne Falls arc, and these ages were recently refined with single grain U-Pb CA-IDTIMS on zircon to circa $475 \mathrm{Ma}$ (Macdonald and others, 2014). Coeval ashes have not been identified in Early Ordovician strata of eastern Laurentia. This could either be due to paleogeographic separation between these arcs and the Laurentian margin, poor preservation potential in peri-tidal strata, erosion of foreland basins during subsequent orogeny, burial beneath thrust sheets, or the direction of trade winds. The lower portion of the $\sim 1 \mathrm{~km}$ thick Barnard Volcanic Member was previously dated with multi-grain U-Pb TIMS on zircon with an upper intercept date of $471.4 \pm 3.7 \mathrm{Ma}$ (Karabinos and others, 1998) and the upper portion was recently dated with U-Pb CA-IDTIMS on zircon to $466.00 \pm 0.14 \mathrm{Ma}$ (Karabinos and others, 2017). 480 to $462 \mathrm{Ma}$ and 458 to $445 \mathrm{Ma}$ magmatism has also been identified in the Ammonoosuc Volcanics of New Hampshire (Moench and Aleinikoff, 2003; Aleinikoff, 2015), which have been included with the Bronson Hill arc. Previous studies have 
included the Bronson Hill arc with the leading edge of Gander (van Staal and others, 1998; Hibbard and Karabinos, 2013; van Staal and others, 2016), but we suggest that this arc formed on the margin of Laurentia after collision of the peri-Gondwanan Moretown terrane (Karabinos and others, 2017), which is consistent with paleomagnetic studies (Wellensiek and others, 1990; Potts and others, 1993; Potts and others, 1995). Late Ordovician magmatism also occurs in Massachusetts (Tucker and Robinson, 1990) and Connecticut (Sevigny and Hanson, 1993; Sevigny and Hanson, 1995; Walsh and others, 2004; Chu and others, 2016).

Along with Ordovician magmatism, previous studies have documented Ordovician metamorphism in the hinterland (Tremblay and Pinet, 2016). In the Rowe belt of Northern Vermont, 486 to 473 Ma Ar-Ar metamorphic cooling dates have been reported from amphiboles in mafic schists (Laird and others, 1984; Castonguay and others, 2012). Metamorphic Ar-Ar cooling dates between 471 and 460 Ma were also reported in the Laurentian rift-drift succession and the Rowe belt (Laird and others, 1984; Castonguay and others, 2012). In southern Québec, the circa 480 Ma ThetfordMines ophiolite was obducted onto the Laurentian margin and intruded by granites by circa $470 \mathrm{Ma}$ (Whitehead and others, 2000), consistent with 479 to $472 \mathrm{Ma}$ Ar-Ar metatmorphic ages of the infraophiolitic metamorphic sole (De Souza and others, 2011; Tremblay and others, 2011). Metamorphic ages between 465 and 457 Ma were also obtained in the ophiolites and surrounding metasediments in the Mont-Albert Complex, which coincides with deposition of the Saint-Daniel and Riviere-Port-Daniel mélanges (Schroetter and others, 2006; De Souza and others, 2011). Similar Ar-Ar white mica dates of $463 \pm 5 \mathrm{Ma}$ have been reported from metamorphosed Laurentian passive margin deposits in Québec (Whitehead and others, 1996). A second Ordovician metamorphic event occurred during the Late Ordovician emplacement of the Taconic allochthon (Bosworth and others, 1988).

Although ashes within the Indian River Formation and the Trenton Group have not been directly dated prior to this study, previous geochronology has been reported from Middle and Late Ordovician bentonites in the midcontinent and Newfoundland. More than 60 ash beds have been identified in Ordovician basins of eastern North America (Kolata and others, 1996) and many of these have been correlated regionally using tephrachronology (Delano and others, 1994; Adhya, ms, 2009; Sell and others, 2015). Most of these ashes are Late Ordovician, but Middle Ordovician ash beds have been identified and two have been dated in Newfoundland with single grain U-Pb CA-IDTIMS zircon at $464.5 \pm 0.4$ and $464.5 \pm 1.0 \mathrm{Ma}$ (Sell and others, 2011). The next oldest ashes that have been identified are in the Sandbian Tyrone Formation and its equivalents, and the oldest dated ash bed is the Deicke ash, which has been dated with single grain U-Pb CA-IDTIMS zircon at $453.7 \pm 0.6 \mathrm{Ma}$ (Sell and others, 2013). Using multi-grain zircon fractions, Tucker and others (1990) dated the Milbrig ash in Missouri with U-Pb at 453.7 $\pm 1.8 \mathrm{Ma}$. This bed was later dated with Ar-Ar at 455.1 \pm 1.7 Ma (Smith and others, 2011) and then with single grain U-Pb CA-IDTIMS zircon at $452.9 \pm 0.3 \mathrm{Ma}$ (Sell and others, 2013). Katian ashes in the midcontinent (Dygerts and Rifle Hill bentonites), potentially correlative with ashes in the Trenton Shale, have been dated with Ar-Ar at 451.6 \pm 1.7 Ma and 451.2 \pm 2.1 Ma (Smith and others, 2011).

In summary, previous geochronology suggested multiple Ordovician pulses or 'flare-ups' of magmatism and metamorphism in the Early to Middle Ordovician; however, in New England, only Late Ordovician magmatism has been documented in the form of ashes on the North American margin. In the companion paper (Karabinos and others, 2017), we refine the magmatic ages in the hinterland, and demonstrate with detrital zircon studies that magmatism occurred on the Laurentian margin after the Early Ordovician accretion of the Moretown terrane. In this contribution, we then 
relate the magmatism, metamorphism, and deposition in the foreland basins to the evolving plate tectonic geometry and setting of the arcs.

\section{METHODS}

Coarse-grained siliciclastic units and K-bentonite beds interpreted as devitrified volcanic ashes were sampled for geochronological studies. K-Bentonite beds and fine-grained sedimentary rocks from the Giddings Brook slice and Mohawk valley were also sampled for whole rock geochemistry. Analytical methods are described in detail in the Appendix. Complete $\mathrm{U}$ and $\mathrm{Pb}$ isotopic and whole rock geochemical data are given in tables A1, A2, and A3 (http://earth.geology.yale.edu/ ajs/Supplementary Data/2017/Macdonald) and plotted in figures 8 and 9 . The results are discussed in stratigraphic order below.

Slate was sampled within measured stratigraphic sections of the Cambrian and Ordovician succession exposed in the Giddings Brook slice of New York for Nd isotope analyses to track the provenance of fine grain sediment. The initial epsilon $\mathrm{Nd}(\varepsilon \mathrm{Nd})$ values of bulk sedimentary rocks tracks the average value of their parent rock because $\mathrm{Sm} / \mathrm{Nd}$ ratios are not readily affected by weathering or diagenesis and because these elements are insoluble and have a short residence time in seawater (McLennan and others, 1993). Sediments deriving from a highly evolved source, such as old continental craton should have relatively negative $\varepsilon N d$ values that reflect older mantle extraction ages, whereas sediments deriving from a juvenile source, such as a young arc terrane should have more positive $\varepsilon N d$ values that reflect juvenile sources with younger mantle extraction ages (McLennan and others, 1993). Analytical methods are described in detail in the Appendix. Complete $\mathrm{Nd}$ isotopic data are given in table A4 (http:/ / earth.geology.yale.edu/ ajs/SupplementaryData/2017/Macdonald) and plotted in figure 5.

Carbonate and carbonate-rich shale were sampled during the coarse of measuring stratigraphic sections of the Trenton Group. Carbonate carbon $\left(\delta^{13} \mathrm{C}\right)$ and oxygen $\left(\delta^{18} \mathrm{O}\right)$ isotopic measurements were obtained on 264 samples. Samples were microdrilled along individual laminations, where visible, to obtain 5 to $20 \mathrm{mg}$ of powder; veins, fractures, and siliciclastic-rich areas were avoided. Analytical methods are described in detail in the Appendix. Complete carbon and oxygen isotopic data are given in table A5 (http://earth.geology.yale.edu/ ajs/SupplementaryData/2017/ Macdonald) and plotted in figure 4 .

With a refined age model, a subsidence analysis was performed on four successions in the Champlain Valley of New York and Vermont. These localities were chosen because to the south and west in the Mohawk Valley, the Early and Middle Ordovician are largely missing below the Late Ordovician sub-Trenton Group unconformity, and to the east in the Taconic allochthon, stratigraphic thicknesses are compromised by metamorphism. Subsidence analysis was done using Backstrip v. 4.0 by Nestor Cardozo: http://www.ux.uis.no/ nestor/work/programs.html. Backstrip performs 1D Airy backstripping with exponential reduction of porosity, based on Allen and Allen (2013). Values for porosity coefficients, sediment grain density, and surface porosity were modified from Allen and Allen (2013). The porosity coefficient used for shale was $0.51 / \mathrm{km}$, sandstone $0.27 / \mathrm{km}$, mixed sandstone and shale $0.39 / \mathrm{km}$, limestone 0.52 , and dolomite 0.22 . The sediment grain density used from shale was 2.72 $\mathrm{g} / \mathrm{cm}^{3}$, sandstone $2.65 \mathrm{~g} / \mathrm{cm}^{3}$, mixed sandstone and shale $2.68 \mathrm{~g} / \mathrm{cm}^{3}$, limestone $2.71 \mathrm{~g} / \mathrm{cm}^{3}$, and dolomite $2.85 \mathrm{~g} / \mathrm{cm}^{3}$. The surface porosity used for shale was 63 percent, sandstone 49 percent, mixed sandstone and shale 56 percent, limestone 51 percent, and dolomite 30 percent. Ages used for stage boundaries are from Gradstein and others (2012). Age model and thicknesses for units in the Giddings Brook slice were modified from Landing (2012) and Rowley and others (1979). Age model and thicknesses for units in the Western Cover Sequence was modified from 
Washington and Chisick (1994), Mehrtens and others (1995), and Landing (2012). Age model and thicknesses for units in the Champlain Valley was modified from Landing (2012), Landing and others (2003), Mehrtens and others (1995), Brett and Westrop (1996), and Dix and others (2013). Age model and thicknesses for units in the Mohawk Valley are modified from Landing (2012) Landing and others (2003), and Mitchell and others (1994). Data used in subsidence model are shown in table A6 (http://earth.geology.yale.edu/ ajs/SupplementaryData/2017/ Macdonald) and plotted in figure 10.

RESULTS

\section{U-Pb Geochronology}

Samples are organized below from oldest to youngest in New York and then Newfoundland. LA-ICPMS detrital zircon spectra of samples from the Taconic allochthon are plotted in figure 5. Ranked date plots of dated samples are plotted in figure 8.

Sample F1454: Browns Pond Formation.-A clean, channelized quartz-arenite in black slate in the Mud Pond Member of the Browns Pond Formation collected on the Metawee River, just below the first riffles after the Metawee River Falls at N43 $27.119^{\prime}$, W73 $19.854^{\prime}$. LA-ICPMS on 101 zircon grains yielded a prominent peak at $1.1 \mathrm{Ga}$ that tails toward $1.4 \mathrm{Ga}$. The five youngest grains were analyzed with multiple spots that yield weighted mean dates of $649 \pm 27 \mathrm{Ma}(\mathrm{n}=3$, MSWD $=1.2$, probability of fit $[\mathrm{POF}]=0.29), 586 \pm 26 \mathrm{Ma}(\mathrm{n}=3, \mathrm{MSWD}=0.4, \mathrm{POF}=0.65), 564 \pm 21 \mathrm{Ma}(\mathrm{n}=2$, $\mathrm{MSWD}=0.5, \mathrm{POF}=0.50), 564 \pm 27 \mathrm{Ma}(\mathrm{n}=3, \mathrm{MSWD}=0.9, \mathrm{POF}=0.40)$, and $530 \pm$ $25(\mathrm{n}=3, \mathrm{MSWD}=0.01, \mathrm{POF}=0.99)$. Two fragments from the grain with a weighted mean of $530 \pm 25$ Ma yielded CA-IDTIMS dates of $548.53 \pm 0.37$ and $547.96 \pm 0.36 \mathrm{Ma}$. The grain with a weighted mean of $564 \pm 27$ Ma yielded a CA-IDTIMS date of $580.46 \pm$ $0.39 \mathrm{Ma}$.

Sample F1452: Hatch Hill Formation.-A poorly lithified $\sim 10 \mathrm{~cm}$ 'rottenstone' consisting of coarse sandstone with goethite cement in a sea of black slate collected along Tanner Hill Road at N43 ${ }^{\circ} 29.265^{\prime}, \mathrm{W}^{\circ} 3^{\circ} 18.861^{\prime}$. This bed is interpreted as a turbidite from the Laurentian margin. LA-ICPMS on 101 zircon grains yielded peaks at $1.1,1.4$, and $2.7 \mathrm{Ga}$. There is one younger grain that was analyzed twice and yielded a weighted mean date of $486 \pm 29 \mathrm{Ma}(\mathrm{MSWD}=1.0, \mathrm{POF}=0.33)$.

Sample F1453: Poultney Formation.-A $5 \mathrm{~cm}$ thick quartzite bed within greenish-gray slate beds of the Poultney Formation collected along Tanner Hill Road $\sim 25 \mathrm{~m}$ up-section (west) of F1452 at N43 $29.261^{\prime}$, W73 ${ }^{\circ} 18.915^{\prime}$. LA-ICPMS on 90 zircon grains yielded peaks at 1.1, 1.4 and 2.7 Ga. There are no dates $<900 \mathrm{Ma}$.

Sample F1450: Indian River Formation.-A $0.5 \mathrm{~m}$ thick, massive, silicified bed of green slate with white quartz-rich stringers that include quartz fragments up to gravel size collected in a red slate quarry at $\mathrm{N}^{\circ} 3^{\circ} 29.518^{\prime}, \mathrm{W}^{\circ} 3^{\circ} 19.118^{\prime}$ (fig. 4B). Zircon is sharply faceted or rounded, and subequal amounts of each population were analyzed. LA-ICPMS on 104 zircon grains yielded a sharp peak at $\sim 450 \mathrm{Ma}$ with minor peaks between 1.1 to $1.3 \mathrm{Ga}$ and at $2.7 \mathrm{Ga}$. Fifty-one of the 52 dates that are $>1.0 \mathrm{Ga}$ are from rounded grains. The youngest 49 dates yielded a weighted mean of $453 \pm 7 \mathrm{Ma}$ $(\mathrm{MSWD}=0.8, \mathrm{POF}=0.89) ; 44$ of these dates are from sharply faceted grains. The rounded grains are interpreted as being detrital rather than inherited in the magma that erupted the volcanic ash because CL images show there are no magmatic rims and the rounded exterior suggests they underwent fluvial transport. The sharply faceted grains are interpreted as being primary volcanic zircon. Six grains were analyzed by CA-IDTIMS, the three youngest of which yielded a weighted mean of $466.06 \pm$ $0.21 / 0.30 / 0.57 \mathrm{Ma}(\mathrm{MSWD}=2.5, \mathrm{POF}=0.08)$. This is the interpreted eruption age. Other grains yielded dates of $467.92 \pm 0.36,467.95 \pm 0.37$, and $468.27 \pm 0.37$ Ma that are interpreted as being the ages of inherited or detrital grains. 
Sample F1455: Indian River Formation.-Apple-green bentonite collected in a red slate quarry at $\mathrm{N}^{\circ} 3^{\circ} 28.942^{\prime}, \mathrm{W}^{\circ} 3^{\circ} 19.100^{\prime}$. LA-ICPMS was performed on 12 zircon grains, the 8 youngest of which yielded a weighted mean date of $451 \pm 9 \mathrm{Ma}$ (MSWD = 1.3 , POF $=0.26$ ). Three other grains yielded dates between 1.1 and $1.5 \mathrm{Ga}$ and are interpreted as being detrital rather than inherited in the magma that produced the ash because CL images show there are no magmatic rims.

Sample F1456: Indian River Formation.-Apple-green bentonite collected in a red slate quarry $9.2 \mathrm{~m}$ above $\mathrm{F} 1455$ at $\mathrm{N} 43^{\circ} 28.960^{\prime}$, W73 $19.098^{\prime}$. Zircon is sharply faceted or round, and some of each population were analyzed. LA-ICPMS on 58 zircon grains yielded a sharp peak at $\sim 450$ Ma with minor peak between 1.0 and $1.4 \mathrm{Ga}$. All $>1.0 \mathrm{Ga}$ grains are round. The youngest 49 dates yielded a weighted mean of $456 \pm 7 \mathrm{Ma}$ $(\mathrm{MSWD}=0.9, \mathrm{POF}=0.65)$ and 47 are from sharply faceted grains. The round grains are interpreted as being detrital rather than inherited in the magma that produced the ash because CL images show there are no magmatic rims and the round exterior suggests they underwent fluvial transport. The sharply faceted grains are interpreted as being primary volcanic zircon. Six grains analyzed by CA-IDTIMS yielded a weighted mean of $464.20 \pm 0.13 / 0.26 / 0.55 \mathrm{Ma}(\mathrm{MSWD}=0.8, \mathrm{POF}=0.58)$. This is the interpreted eruption age.

Sample F1448: Austin Glen Formation.-An immature feldspar-lithic-quartz arenite in a graded, m-thick bed collected under the Metawee Bridge on Lower Turnpike Road at N43 $27.228^{\prime}, \mathrm{W}^{\circ} 3^{\circ} 20.465^{\prime}$. LA-ICPMS on 130 zircon grains yielded a broad peak between 1.0 and $1.3 \mathrm{Ga}$, a small number of Paleoproterozoic and Archean grains, and one $714 \pm 41 \mathrm{Ma}$ grain that was potentially derived from an accreted periGondwanan terrane.

Sherman Falls: Flat Creek Member, Trenton Group.-Ash collected at negative $4.0 \mathrm{~m}$ in the Flat Creek section of Delano and others (1994) at N42 $52.069^{\prime}$, W74 $32.266^{\prime}$ and correlated with geochemistry of inclusions in quartz phenocrysts with an ash at $14.5 \mathrm{~m}$ from the base of the Trenton Group at Canajoharie Creek (Delano and others, 1994). Eight grains were analyzed by CA-IDTIMS, the five youngest of which yielded a weighted mean date of $452.63 \pm 0.06 / 0.23 / 0.52 \mathrm{Ma}(\mathrm{MSWD}=1.7, \mathrm{POF}=0.14)$. This is the interpreted eruption age. Three other grains yielded a weighted mean date of $452.82 \pm 0.08 / 0.23 / 0.53 \mathrm{Ma}(\mathrm{MSWD}=0.2, \mathrm{POF}=0.86)$ that is interpreted as the age of inherited or detrital components.

Chuctanunda: Flat Creek Member, Trenton Group.-Ash collected at $37.5 \mathrm{~m}$ in Chuctanunda Creek of Delano and others (1994) at N42 $54.869^{\prime}$, W74 ${ }^{\circ} 13.792^{\prime}$ and correlated with geochemistry of inclusions in quartz phenocrysts with an ash at $55.2 \mathrm{~m}$ from the base of the Trenton Group at Canajoharie Creek (Delano and others, 1994). LA-ICPMS on 29 grains yielded 28 dates between $435 \pm 11$ and $500 \pm 38 \mathrm{Ma}$ and one at $1187 \pm 50 \mathrm{Ma}$. It cannot be determined whether the oldest grain was inherited in the magma that produced the ash or incorporated as a detrital component. The 20 youngest dates yielded a weighted mean of $449 \pm 10 \mathrm{Ma}(\mathrm{MSWD}=1.4, \mathrm{POF}=0.10)$. Eight grains analyzed by CA-IDTIMS yielded a weighted mean date of $451.71 \pm$ $0.13 / 0.25 / 0.53 \mathrm{Ma}(\mathrm{MSWD}=1.3, \mathrm{POF}=0.24)$. This is the interpreted eruption age.

F1302_1.8: Dolgeville Formation, Trenton Group.-The Manheim ash collected at Nowadaga Creek at N42 $59.724^{\prime}$, W74 ${ }^{\circ} 47.286^{\prime}$. LA-ICPMS on 56 zircon grains yielded a large peak $\sim 445 \mathrm{Ma}$ and four dates at 1.0 to $1.1 \mathrm{Ga}$, one at $1.4 \mathrm{Ga}$, and one at $1.6 \mathrm{Ga}$. Thirty-seven dates yielded a weighted mean of $444 \pm 6 \mathrm{Ma}(\mathrm{MSWD}=1.2, \mathrm{POF}=0.20)$. CL images show a wide variety of CL brightness and zoning patterns, with many of the grains having inherited cores (fig. 7). The 1.0 to 1.6 Ga dates are from cores that are surrounded by CL dark rims that appear identical to the $\sim 445 \mathrm{Ma}$ zircon. Therefore, these cores are interpreted as being inherited in the magma that produced the ash. There are also many cores that yielded $\sim 445$ Ma dates, showing that there was also 


\section{Grenville Inheritance}
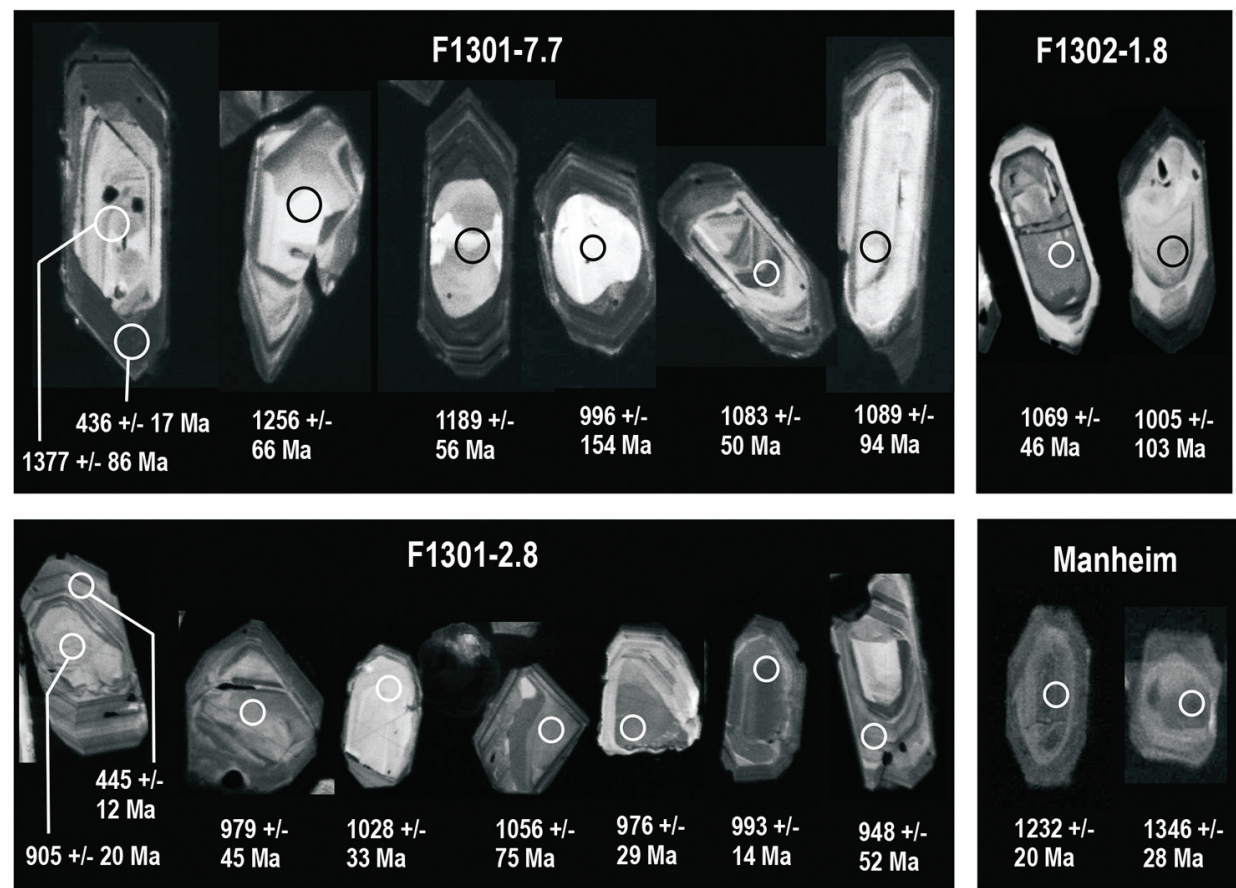

\section{Taconic Inheritance}
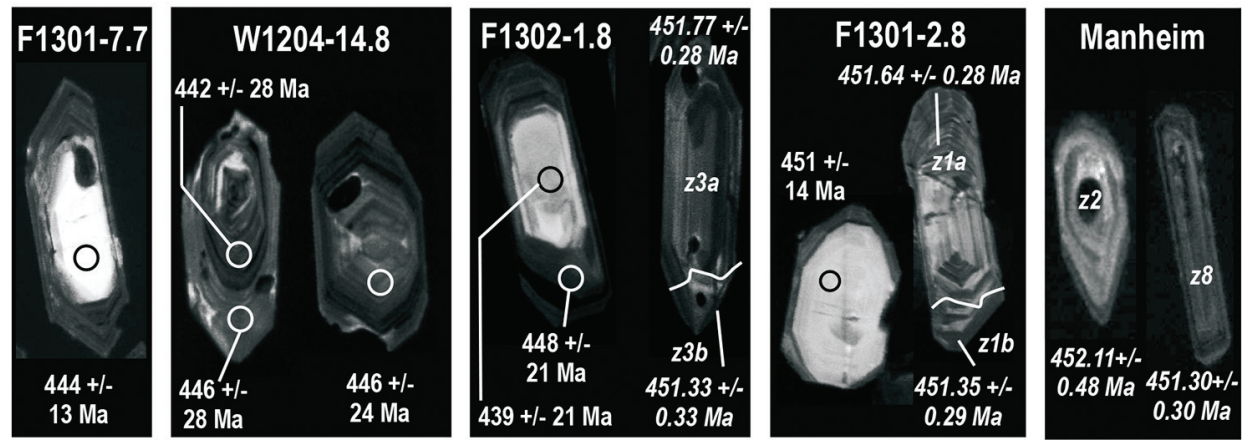

Fig. 7. Cathodoluminescence (CL) images of zircon with LA-ICPMS dates on individual grains from ashes in the Trenton Group. Note that complete CL images can be found in online supplement.

inheritance of cores that are slightly older than eruption (fig. 7). Nine analyses from five CL dark grains that appear to lack cores yielded equivalent dates with a weighted mean of $451.42 \pm 0.10 / 0.24 / 0.53 \mathrm{Ma}(\mathrm{MSWD}=1.2, \mathrm{POF}=0.32)$ (fig. 8).

Manheim, Dolgeville Formation, Trenton Group.-The Manheim bentonite sample was collected in North Creek (accessed via Myers Road) at N43 ${ }^{\circ} 5.330^{\prime}$, W74 ${ }^{\circ} 55.943^{\prime}$, and has been correlated by quartz glass inclusion geochemistry with the Manheim Ash from the eponymous locality (Adhya, ms, 2009). LA-ICPMS on 26 grains, yielded a large peak at $\sim 450 \mathrm{Ma}$ and five dates between 1.1 and $1.3 \mathrm{Ga}$. Fourteen dates yielded a weighted mean of $448 \pm 7 \mathrm{Ma}(\mathrm{MSWD}=1.2, \mathrm{POF}=0.25)$. CL images (fig. 7$)$ indicate 


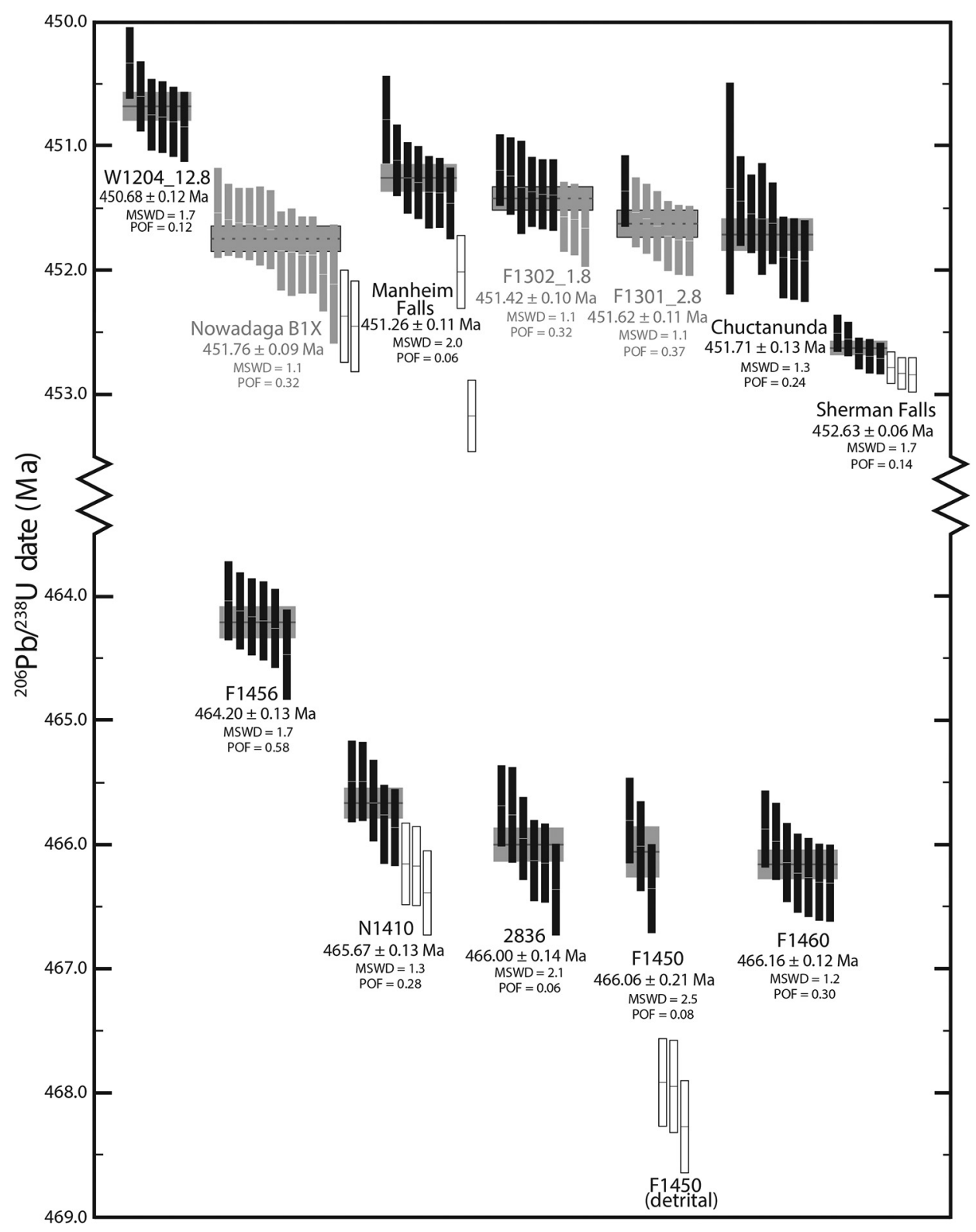

Fig. 8. Ranked date plots of ashes in the Trenton Group in the Mohawk Valley of New York, the Indian River Formation of the in the Giddings Brook slice of New York, and the Humber margin of Newfoundland, compared to data from sample 2836, which is the Barnard Volcanic Member in Vermont (Karabinos and others, 2017). Black bars are included in regression and are interpreted as magmatic, gray bars are included in regression but are interpreted as inherited due to out of sequence dates, and unfilled bars are interpreted as inherited and not included in regression. Geochronological data is provided in the supplementary materials table S2, http://earth.geology.yale.edu/ ajs/SupplementaryData/2017/Macdonald.

that 1.1 to 1.3 Ga grains were inherited in the magma that produced the ash. Nine grains were analyzed by CA-IDTIMS, the seven youngest of which yielded a weighted mean date of $451.26 \pm 0.11 / 0.25 / 0.53 \mathrm{Ma}(\mathrm{MSWD}=2.0, \mathrm{POF}=0.06)($ fig. 8$)$. This is 
the interpreted eruption age. Other grains yielded dates of $452.02 \pm 0.30$ and $453.17 \pm$ $0.29 \mathrm{Ma}$ that are interpreted from CL images as being the ages of inherited components.

F1301_2.8:Dolgeville Formation, Trenton Group.-Manheim Ash recollected in North Creek at N43 $5.330^{\prime}, \mathrm{W}^{\circ} 4^{\circ} 55.943^{\prime}$, which can be accessed from Myers Road. LA-ICPMS on 48 zircon grains yielded a large peak at $\sim 450 \mathrm{Ma}$ and nine dates at $\sim 1.0 \mathrm{Ga}$. The 27 youngest dates yielded a weighted mean of $450 \pm 7 \mathrm{Ma}(\mathrm{MSWD}=1.5, \mathrm{POF}=0.05)$. CL images show a wide variety of CL brightness and zoning patterns, with many of the grains having inherited cores (fig. 7). The $1.0 \mathrm{Ga}$ dates are from cores that are surrounded by CL dark rims that appear identical to the $\sim 450 \mathrm{Ma}$ zircon; this was confirmed by LA-ICPMS on one grain (fig. 7). Therefore, these cores are interpreted as being inherited in the magma that produced the ash. There are also many cores that yielded $\sim 450 \mathrm{Ma}$ dates, as well as grains with slightly older dates, showing that there was also inheritance of zircon that is slightly older than the eruption. Seven grains analyzed by CA-IDTIMS yielded a weighted mean of $451.62 \pm 0.11 / 0.24 / 0.53 \mathrm{Ma}(\mathrm{MSWD}=1.1$, $\mathrm{POF}=0.37)$ that is interpreted as being the age of inherited components.

Nowadaga B1X: Indian Castle Formation, Trenton Group.-Ash collected at Nowadaga Creek at $\mathrm{N}^{\circ} 2^{\circ} 59.724^{\prime}, \mathrm{W} 74^{\circ} 47.286^{\prime}$. LA-ICPMS on 18 grains yielded scattered dates between $432 \pm 13$ and $476 \pm 11 \mathrm{Ma}$. Fourteen grains were analyzed by CA-IDTIMS, the 12 youngest of which yielded a weighted mean date of $451.76 \pm 0.09 / 0.24 / 0.53 \mathrm{Ma}$ $(\mathrm{MSWD}=1.1, \mathrm{POF}=0.32)$. This is the interpreted eruption age. Two other grains yielded a weighted mean date of $452.41 \pm 0.26 / 0.34 / 0.58 \mathrm{Ma}(\mathrm{MSWD}=0.1, \mathrm{POF}=$ 0.76 ) that is interpreted as being the age of inherited or detrital components.

F1301_7.7: Indian Castle Formation, Trenton Group.-Ash collected in North Creek (accessed via Myers Road) at N43 ${ }^{\circ} 5.330^{\prime}$, W74 ${ }^{\circ} 55.943^{\prime}$, and correlated by quartz glass inclusion geochemistry with the Countryman Ash (Adhya, ms, 2009). LA-ICPMS on 47 zircon grains yielded a large peak at $\sim 450 \mathrm{Ma}$ and 10 dates between 1.0 and $1.4 \mathrm{Ga}$. Thirty-two dates yielded a weighted mean of $449 \pm 6 \mathrm{Ma}(\mathrm{MSWD}=1.2, \mathrm{POF}=0.21)$. CL images show a wide variety of CL brightness and zoning patterns, with many of the grains having inherited cores (fig. 7). The 1.0 to $1.4 \mathrm{Ga}$ dates are from cores that are surrounded by CL dark rims that appear identical to the $\sim 450 \mathrm{Ma}$ zircon; this was confirmed by LA-ICPMS on one grain (fig. 7). Therefore, these cores are interpreted as being inherited in the magma that produced the ash.

W1204_14.8: Indian Castle Formation, Trenton Group.-Ash was collected in the uppermost exposures at Nowadaga Creek at N42 $59.205^{\prime}$, W74 $48.401^{\prime}$. LA-ICPMS on 45 zircon grains yielded a large peak at $\sim 440 \mathrm{Ma}$ and one date at $1163 \pm 73 \mathrm{Ma}$. Forty dates yielded a weighted mean of $442 \pm 6 \mathrm{Ma}(\mathrm{MSWD}=0.7, \mathrm{POF}=0.94)$. It cannot be determined whether the $1.1 \mathrm{Ga}$ grain was inherited in the magma that produced the ash or incorporated as a detrital component. Six grains analyzed by CA-IDTIMS yielded a weighted mean date of $450.68 \pm 0.12 / 0.25 / 0.53 \mathrm{Ma}(\mathrm{MSWD}=1.7, \mathrm{POF}=$ $0.12)$. This is the interpreted eruption age.

F1460: Humber Arm Allochthon.-Ash collected along the coast of West Cove at $\mathrm{N} 48^{\circ} 35.592^{\prime}$, W58 $55.082^{\prime}$. LA-ICPMS on 39 zircon grains yielded a large peak at $\sim 460$ Ma and two other dates at $1326 \pm 49$ and $2505 \pm 31$ Ma. The youngest 37 dates yielded a weighted mean of $463 \pm 6 \mathrm{Ma}(\mathrm{MSWD}=1.3, \mathrm{POF}=0.12)$. It cannot be determined whether the 1.3 and $2.5 \mathrm{Ga}$ grains were inherited in the magma that produced the ash or incorporated as a detrital component. Seven grains analyzed by CA-IDTIMS yielded a weighted mean date of $466.16 \pm 0.12 / 0.25 / 0.55 \mathrm{Ma}(\mathrm{MSWD}=1.2, \mathrm{POF}=0.30)$. This is the interpreted eruption age.

N1410: Black Cove Formation.-Ash collected at Black Cove at N48 34.997', W58 $41.769^{\prime}$. LA-ICPMS on 45 zircon grains yielded a large peak at $\sim 460$ Ma and 11 other dates between 1.0 and $1.5 \mathrm{Ga}$. Thirty dates yielded a weighted mean of $461 \pm 6 \mathrm{Ma}$ 
$(\mathrm{MSWD}=1.4, \mathrm{POF}=0.06)$. The 1.0 to $1.5 \mathrm{Ga}$ dates are from cores that are surrounded by CL dark rims that appear identical to the $\sim 460 \mathrm{Ma}$ zircon. Therefore, these cores are interpreted as being inherited in the magma that produced the ash. Eight grains analyzed by CA-IDTIMS yielded a weighted mean date of $465.67 \pm 0.14 / 0.27 / 0.55 \mathrm{Ma}(\mathrm{MSWD}=1.3, \mathrm{POF}=0.28)$. This is the interpreted eruption age. Three other grains yielded a weighted mean date of $466.23 \pm 0.19 / 0.29 / 0.57 \mathrm{Ma}(\mathrm{MSWD}=0.6, \mathrm{POF}=0.54)$ that is interpreted as being the age of inherited or detrital components.

\section{Whole Rock Geochemistry}

Following Winchester and Floyd (1977), we use $\mathrm{Zr} / \mathrm{TiO}_{2}$ versus $\mathrm{Nb} / \mathrm{Y}$ to determine the composition of the original magma that produced the K-bentonites in the Trenton Group. The chemistry of these ashes plot predominantly in the rhyodacite to trachyandesite fields with a few outliers in the alkai basalt field (fig. 9A).

$\mathrm{Al}, \mathrm{Ti}$, and $\mathrm{Zr}$ were selected for describing the whole rock chemical compositions of Taconic sedimentary rocks due to those elements being diagenetically immobile under most conditions. As a result, the ratios of those elements in the rocks are likely to be equivalent to those in the original sediments. Figures $9 \mathrm{~B}$ and $9 \mathrm{C}$ show the whole rock compositions in the allochthonous and autochthonous sequences, respectively. The Cloridorme Formation, which is a Taconic-age flysch from the Gaspé Peninsula of Québec, contains large contributions from mafic and ultramafic components (Hiscott, 1984; Hiscott and others, 1986; Garver and others, 1996), and is shown for comparison in both ternary figures.

Figures $9 \mathrm{~B}$ and $9 \mathrm{C}$ distinguish the compositional effects on the whole rock compositions due to both sorting (for example, grain size) between $\mathrm{Al}$ and $\mathrm{Zr}$ and changes in provenance with Ti. Figure 9B compares whole rock compositions below and above the flysch at allochthonous sections in the Mohawk Valley, and figure 9C compares whole rock compositions below and above the flysch in the Giddings Brook slice of the Taconic allochthon. While the magnitude of sorting in the samples from the distal margin (Pawlet/Austin Glen) and platform margin (Schenectady/ Frankfort) flysch are different, the overlapping trends indicate that the provenance of detritus for both flysch deposits was indistinguishable. Moreover, there is also no apparent change in Ti content between the Poultney and Indian River formations. In contrast, the composition of the underlying rocks in the distal margin (Poultney, Indian River, and Mount Merino) and platform margin (Utica) sections are moderately displaced from the Pawlet/Austin Glen flysch deposits and strongly displaced from the Cloridorme flysch deposit with respect to Ti. This displacement to higher Ti contents is interpreted as being due to a change in provenance (i.e. an increase in a mafic component) shortly before the onset of flysch deposition. The particularly strong enrichment in the Cloridorme Formation may be due to local sourcing of Ti-rich alkali basalts in the adjacent Shickshock Group (Enos, 1969; Hiscott, 1978).

\section{Nd Isotopes}

Slate samples for Nd isotope analyses were collected through the Hatch Hill and Poultney formations (BN1402) along Tanner Hill Road at N 43 ${ }^{\circ} 29.265^{\prime}$, W $73^{\circ} 18.861^{\prime}$, through the Indian River Formation (BN1403) in a red slate quarry at N $43^{\circ} 28.942^{\prime}$, W $73^{\circ} 19.100^{\prime}$, and through the Mount Merino and Austin Glen formations (F1458) along the Metawee River at N $43^{\circ} 27.228^{\prime}$, W $73^{\circ} 20.465^{\prime}$. Nd isotope analyses yielded $\varepsilon N d$ values between -15 and -9 (fig. 5). An abrupt shift to more positive $\varepsilon N d$ values occurs within the Indian River Formation. These more primitive values continue through the Mount Merino and Austin Glen formations, highlighting a distinct and persistent change in source at the unconformity between the Poultney and Indian River formations. 

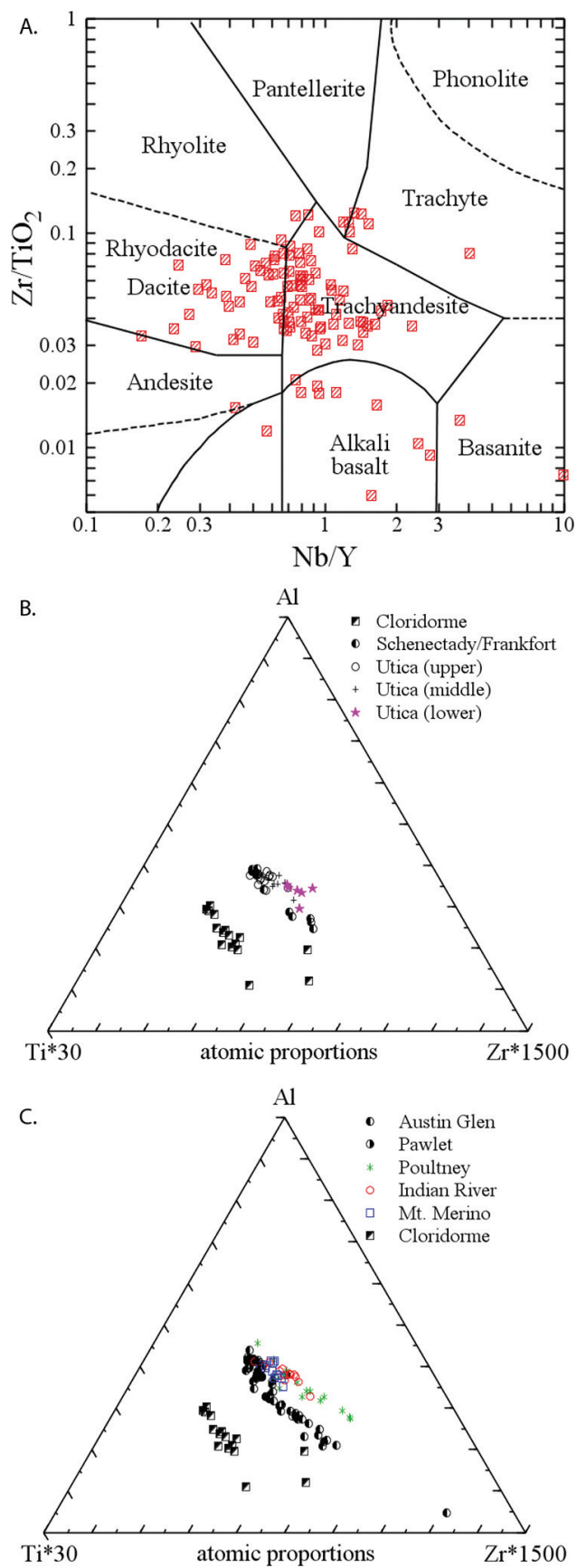

Fig. 9. (A) Whole rock geochemistry of the Taconic K-bentonites. Following Winchester and Floyd (1977), we use $\mathrm{Zr} / \mathrm{TiO}_{2}$ versus $\mathrm{Nb} / \mathrm{Y}$ to classify the differentiation products of subalkaline and alkaline magma series. (B) $\mathrm{Al}, \mathrm{Ti}, \mathrm{Zr}$ ternary diagram of whole rock geochemical compositions of Taconic sedimentary rocks deposited on the platform margin exposed in the Mohawk Valley and (C) on the distal margin preserved in the Taconic allochthon. The Cloridorme Formation, which is a Taconic-age flysch containing large contributions from mafic and ultramafic components (Garver and others, 1996; Hiscott and others, 1986; Hiscott, 1984), is shown for comparison in both ternary figures. 


\section{Carbon and Oxygen Isotopes}

Carbon and oxygen isotopes were analyzed from carbonate samples collected from the North Creek, Small's Bush Road, Nowadaga Creek, Crumb Creek, and Canajoharie Creek sections (fig. 4). Much of what appears as black shale in outcrop of the Trenton Group is micritic limestone with $>50$ percent carbonate content. Comparison of $\delta^{13} \mathrm{C}$ and $\delta^{18} \mathrm{O}$ values between pure carbonate samples and adjacent samples of carbonate-rich marly shale showed no systematic differences. Carbon isotope values are between +4 and $-2 \%$ throughout the Trenton Group with notable positive and negative excursions in the Glen Falls limestone and the top of the Dolgeville Formation (fig. 4). Oxygen isotope values are between -5 and -9 permil throughout the Trenton Group with less depleted values in both the Glen Falls limestone and Dolgeville Formation (fig. 4).

\section{Subsidence Model}

Subsidence curves from the Mohawk Valley, Champlain Valley, the Western cover sequence between the Champlain Thrust and the Green Mountain Massif, and the Giddings Brook slice are consistent with a rift-drift transition near circa $520 \mathrm{Ma}$ (fig. 10), which agrees with previous estimates based on sedimentology (Landing, 2012). As expected, stretching factors increase from the most craton-ward sections in the Mohawk Valley to the most distal margin sections of the Western cover sequence and the Giddings Brook slice from less than 1.15 to greater than 1.30 (fig. 10). However, there is great uncertainty in the amount of attenuation in the Gidding Brook slice sections. We have followed Rowley and others (1979) in restoring the thickness of these sections by 3 times to account for Taconian attenuation, but a smaller estimation would result in a lower stretching factor. Moreover, after the rift-drift transition, the Giddings Brook slice curve flattens, which could be due to being sediment starved (Landing, 2012), in which case the subsidence curve would follow a that for a water-filled basin (fig. 1).

With the exception of the Mohawk Valley, where the Early and Middle Ordovician record is lost below a Late Ordovician unconformity, these curves all show an inflection at $480 \mathrm{Ma}$ from a thermal subsidence curve for a rifted passive margin, in agreement with a previous subsidence model by Washington and Chisick (1994) and their suggestion that this marks the transition from a passive to an active margin. In the Champlain Valley and the Western cover sequence, a subsidence event is present between 466 and $456 \mathrm{Ma}$, and all sections show a significant increase in accommodation in the Late Ordovician (fig. 10).

DISGUSSION

\section{Geochronology and Provenance of Middle Ordovician K-Bentonites and Sedimentary Rocks}

Previous biostratigraphic constraints on the Indian River Formation bracket its age between Early and Late Ordovician graptolites with uncertainty of over 20 million years. Here we show that the Indian River Formation is Middle Ordovician with deposition spanning the ages of the dated ashes at $466.06 \pm 0.20$ and $464.20 \pm 0.13$ Ma. We suggest these ashes are correlative with Middle Ordovician ashes described in the Chazy Group from platform margin sections in Vermont near Lake Champlain (Ryan and others, 2007). These ashes are significantly older than the post-450.71 \pm 0.20 Ma flysch deposits of the Trenton Group (fig. 11). This difference demands reconsideration of previous tectonostratigraphic links between these strata. Additionally, deposition of the Indian River Formation was synchronous with eruption of the $466.00 \pm 0.14$ Ma Barnard Volcanic Member (Karabinos and others, 2017). Thus, we suggest that the late pulse of magmatism in the Shelburne Falls arc, represented by the Barnard Volcanic Member, was the source of the ashes in the Indian River Formation. 


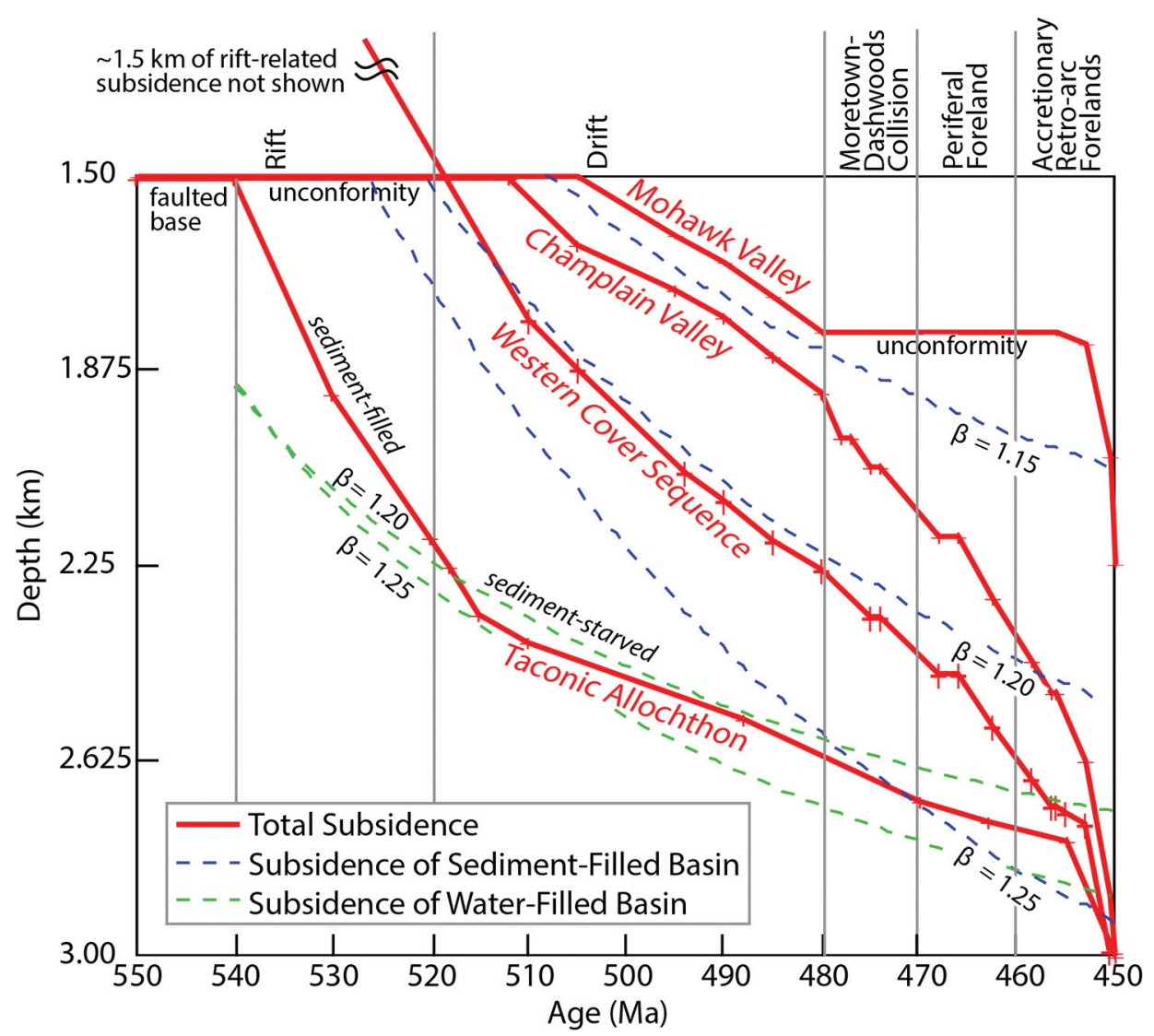

Fig. 10. Total subsidence from backstripping of Paleozoic stratigraphy in the Mohawk Valley of New York, the Champlain Valley of New York and Vermont, the western cover sequence of Vermont, and the Giddings Brook slice of the Taconic allochthon in New York compared to thermal subsidence model of sediment-filled and sediment-starved basins. Subsidence analysis was done using Backstrip v. 4.0 by Nestor Cardozo http://www.ux.uis.no/ nestor/work/programs.html. Backstrip performs 1D Airy backstripping with exponential reduction of porosity, based on Allen and Allen (2013). Details of data used in backstripping are in the supplementary data table S3, http:/ / earth.geology.yale.edu/ ajs/SupplementaryData/2017/ Macdonald. Backstripped subsidence curves are compared graphically with one dimensional thermal subsidence model with uniform stretching (McKenzie, 1978) where total sediment-loaded subsidence (thermal subsidence plus isostatic compensation due to sediment loading) are plotted in blue for variable stretching factors $(\beta)$. We compare backstripped subsidence of the Taconic allochthon to water-loaded subsidence curves in green because after the rift-stage in which substantial sediment loads were delivered, it is thought that the Taconic allochthon was sediment starved (Landing, 2012).

Ashes previously dated from the Table Head Group and Humber arm allochthon (Sell and others, 2013) are slightly younger than those presented here. The position of the ash from the West Quarry dated at $464.5 \pm 0.4$ Ma (Sell and others, 2013) is uncertain compared to the ash dated here on the adjacent coastal exposures at $466.16 \pm 0.12 \mathrm{Ma}$ (fig. 8), but we collected the lower of the two prominent ashes on coastal exposures and we assume they collected the upper bed in the quarry (fig. 6). The slightly older date from the base of shales on the allochthon $466.16 \pm 0.12 \mathrm{Ma}$ compared to that on the autochthon at Black Cove of $465.67 \pm 0.13 \mathrm{Ma}$ is consistent with diachronous foreland development as the load progressed northward.

Most distal ash beds are transported by tropospheric rather than stratospheric winds, particularly heavy minerals such as zircon, as only particles $<4 \mu \mathrm{m}$ rise to the 


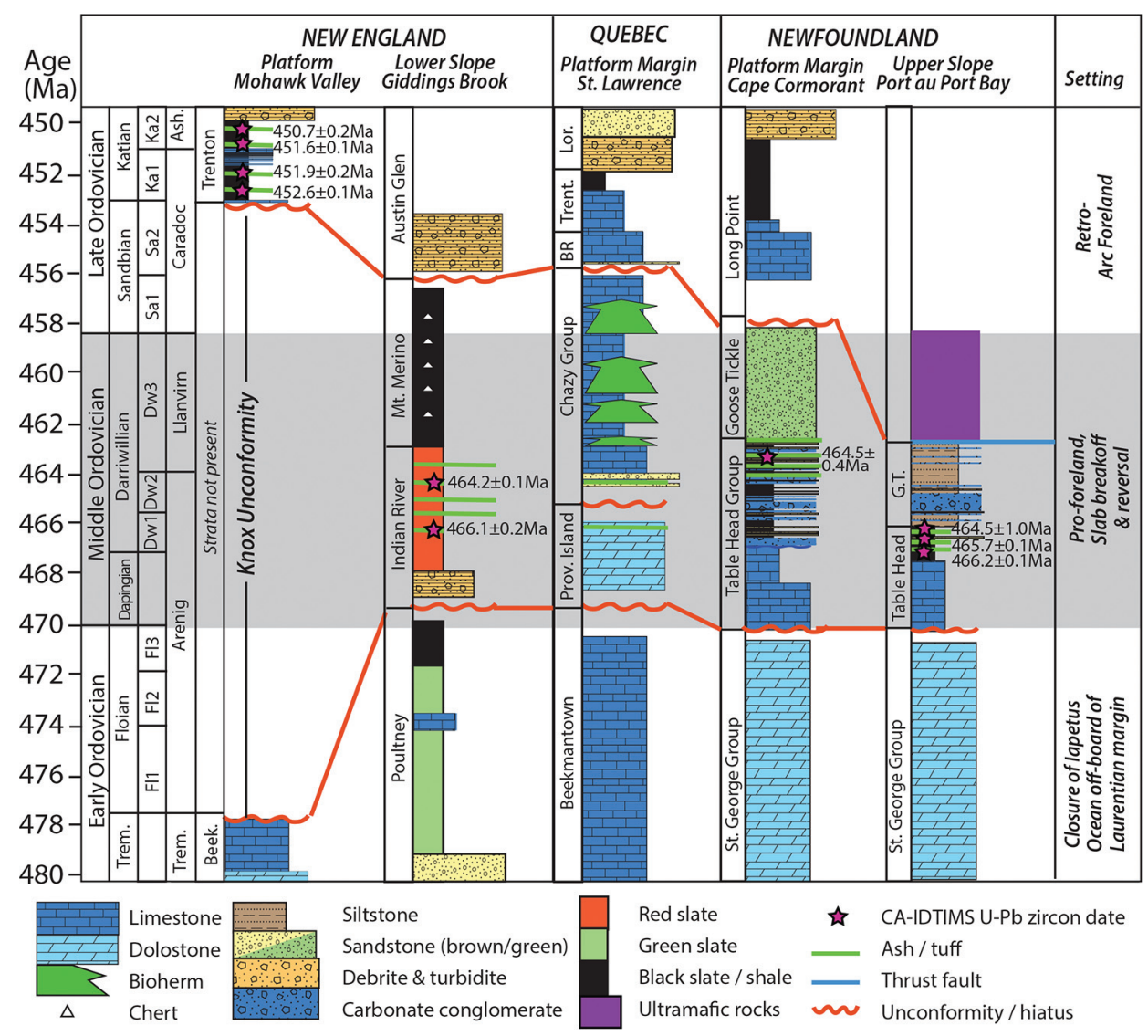

Fig. 11. Correlation diagram between Ordovician sections in the Mohawk Valley of New York, the St. Lawrence Platform of Québec, and the Taconic allochthon of New York. Mohawk Valley stratigraphy is modified from Landing (2012). Québec stratigraphy is modified from Landing (2012) and Dix and others (2013). Newfoundland stratigraphy is modified from James and Stevens (1986) and Stenzel and others (1990). Position of ashes in the Chazy Group is after Ryan and others (2007). Taconic allochthon stratigraphy is modified from Landing (2012) and Rowley and others (1979).

stratosphere (Settle, 1978; Sigurdsson and others, 1980). Paleogeographic models based on synthesized paleomagnetic and geophysical data place the Appalachian margin of Laurentia at or below $\mathrm{S} 20^{\circ}$ for most of the Ordovician (Torsvik and others, 2014; Domeier, 2016). Moreover, low-latitude paleomagnetic poles from the accreted terranes suggest the Appalachian margin was likely even further north (Wellensiek and others, 1990; Johnson and others, 1991; Potts and others, 1993; Potts and others, 1995). Thus, for thick volcanic ashes to appear on the Laurentian margin they had to have erupted from a volcanic arc situated north of the subtropical high at $\sim \mathrm{S} 30^{\circ}$, which separates the trade winds blowing to the northeast, and the westerlies blowing to the southeast. This suggests that the Ordovician volcanic sources had to have been very proximal to the Laurentian margin when they erupted, otherwise the ashes would have blown off-board.

LA-ICPMS dates from ashes in the Indian River Formation yield a sharp peak at circa $470 \mathrm{Ma}$ interpreted as magmatic with minor peaks between 1000 to $1300 \mathrm{Ma}$ and at $2700 \mathrm{Ma}$ (F1450, fig. 5). CL images do not reveal magmatic rims on these inherited grains suggesting that they are detrital rather than xenocrystic (fig. A1, 
http:/ / earth.geology.yale.edu/ajs/SupplementaryData/2017/Macdonald). Along with the Grenvillian age (circa 1000-1250 Ma) peak, 2700 Ma is a common basement age in North America and a common component of detrital zircon in Paleozoic sediments on the Laurentian margin (Cawood and Nemchin, 2001). Thus, while the Indian River Formation was receiving ash from the eruptions, it was also receiving detritus from the Laurentian margin. The F1450 horizon also contains gravel-sized lithic clasts and very coarse quartz grains in graded beds suggesting a local provenance and/or high-energy depositional event. A possible interpretation is that the eruption in the Barnard Volcanic Member was associated with earthquakes and turbidite flows on the Laurentian margin.

Although the collision of the Moretown terrane and the Rowe belt predates the Indian River Formation, detrital zircon provenance does not appear to change in units below and above the Indian River Formation (fig. 5), which have spectra of typical early Paleozoic sediments on the Laurentian margin (Cawood and Nemchin, 2001). We suggest this is due to the localization of deformation and metamorphism at promontories and hyperextended fragments near the suture where circa 480 to $475 \mathrm{Ma} \mathrm{Ar}-\mathrm{Ar}$ metamorphic dates have been reported (Castonguay and others, 2012), east of the Giddings Brook slice. Additionally, the Giddings Brook slice may have been shielded by the New York and St. Laurence promontories from Early and Middle Ordovician metamorphism. Even in the flysch of the Austin Glen Formation, which contains abundant volcanic and metamorphic clasts (Rowley and Kidd, 1981), presumably derived from mafic non-zircon bearing rocks, the detritus is still dominated by Laurentian sources. This highlights a limitation of detrital zircon studies in tectonic forensics: if accretion is off-board and source pathways do not cooperate, the appearance of zircon from accreting terranes may greatly post-date the collision age. That is, detrital zircon studies commonly provide one-sided tests for tectonic models. The presence of a diagnostic population may have great meaning, but its absence may not.

Recognizing this limitation, we performed $\varepsilon N d$ and whole rock geochemical analyses on slate through the Giddings Brook slice stratigraphy to determine when fine-grained sedimentary sources changed in the basin. Previous studies on the Trenton Group documented a shift to more positive $\varepsilon N d$ values up-section from -12 to -8 , indicative of the weathering of more juvenile rocks during Late Ordovician shortening (Andersen and Samson, 1995). Although a previous study of Middle and Early Ordovician strata in New England failed to identify the appearance of juvenile $\varepsilon N d$ trends (Bock and others, 1996), this study was at low resolution with only a couple of samples from the southern portion of the allochthon with poor stratigraphic context and higher metamorphic grade. Although $\varepsilon N d$ in shale is typically unaffected by diagenesis and low-grade metamorphism (McLennan, 1989), several studies have suggested secondary mobility of Nd (Bock and others, 1994; McDaniel and others, 1994; Bock and others, 2004). Slate of the Giddings Brook slice has experienced chlorite grade metamorphism with the conodont alteration index decreasing from 5 in the southern portion of the allochthon to 4 in the north where we sampled (Landing, 2012). Our $\varepsilon N d$ data document a change to more juvenile values in the Indian River Formation that persists through the Mount Merino and Austin Glen formations (fig. $5)$. The signal is inconsistent with diagenesis, which would predict large variation without stratigraphic trends. Moreover, as ash beds are restricted to the Indian River Formation, but the signal persists through the Mount Merino and Austin Glen formations that lack obvious ash beds, these data further argue against merely the mixing of airborne juvenile material, but instead suggest that fine grained sediment with juvenile $\varepsilon \mathrm{Nd}$ from volcanic terranes to the east was being uplifted, eroded, and mixing in with sediment that was primarily derived from Laurentia. However, whole rock data show little change in Ti until the Austin Glen Formation, and even this 


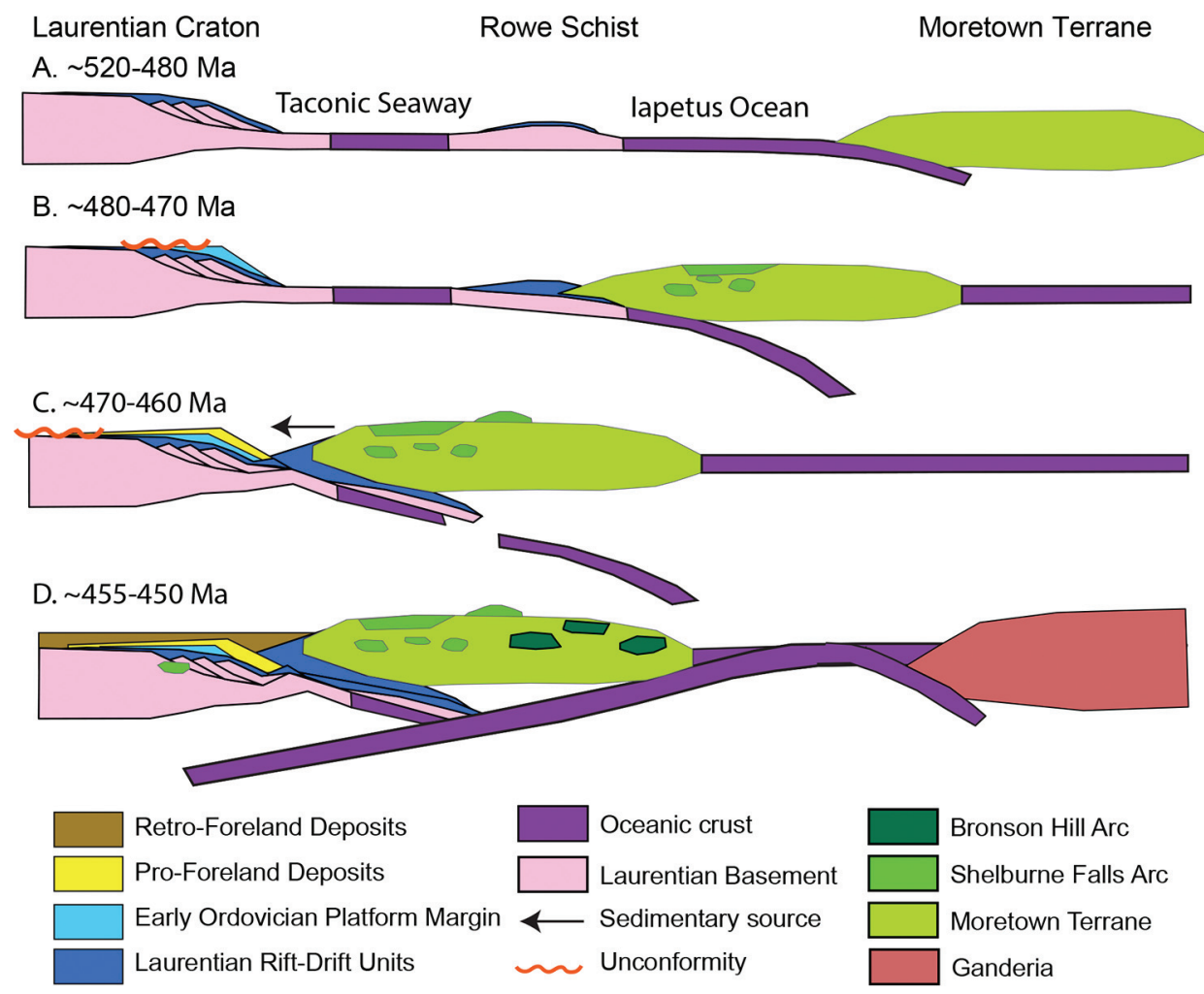

Fig. 12. Schematic cross-sections comparing plate geometry in the hinterland with passive margin and foreland basin deposition on Laurentia. Hinterland plate geometry based on Karabinos and others (2017).

enrichment is far less than that from ophiolite-derived flysch in the Chloridorm Formation (fig. 9). We suggest the change in $\varepsilon N d$ without a discernable change in $\mathrm{Cr}$, $\mathrm{Ni}$, or $\mathrm{Ti}$ is due to the weathering of island arc rhyolites, which are enriched in $\mathrm{Nd}$ but not in $\mathrm{Cr}, \mathrm{Ni}$, or Ti (McLennan and others, 1993; Bock and others, 1996; Garver and others, 1996). This is also consistent with Early to Middle Ordovician lithologies in allochthonous sequences in Vermont, such as the Barnard Volcanic Member. That is, these data herald the appearance of eroded detritus from volcanic arc terranes to the east by circa $466 \mathrm{Ma}$. We attribute this influx of arc detritus to be the result of collision and exhumation of a composite terrane (consisting of Moretown and hyper-extended Laurentian fragments that had previously amalgamated off-board; fig. 12) with the autochthonous Laurentian margin (Macdonald and others, 2014). Collision of the composite terrane was likely associated with slab break-off volcanism in the Shelburne Falls arc and the establishment of the east-facing (present coordinates) Bronson Hills arc on the eastern margin of the composite terrane (Karabinos and others, 2017). The collision and exhumation of the composite terrane and associated ophiolites coincided with deposition of the Middle Ordovician Tourelle Formation on the Gaspé Peninsula of Québec, which contains volcanic fragments and detrital chromite (Hiscott, 1978).

Hiscott (1984) used trace elements to show that many of the Ordovician flysch deposits in the Appalachians were derived from the subaerial weathering of ophiolitic sequences. Middle Ordovician flysch deposits are particularly enriched in $\mathrm{Cr}$ and $\mathrm{Ni}$, 
indicative of direct weathering of ultramafic rocks. The only Late Ordovician Formation that shows strong enrichments in $\mathrm{Cr}$ and $\mathrm{Ni}$ is the Cloridorme Formation, which suggests that the Mt. Albert ophiolite was not completely exhumed and eroded during deposition of the Middle Ordovician Tourelle Formation (Hiscott, 1978), and that the allochthonous sequence including both the Mt. Albert ophiolite and the Tourelle Formation continued to be uplifted and eroded during the Late Ordovician. This is further consistent with metamorphic ages from the Mt. Albert ophiolite, which have yielded significantly younger ages than those in southern Québec (for example, Tremblay and Pinet 2016).

Middle Ordovician flysch deposits have been documented in Tennessee, Pennsylvania, Québec, and Newfoundland, with structural evidence for north-vergent emplacement (present coordinates, Suhr and Cawood, 1993). Revised biostratigraphy also demonstrates that flysch in the Hamburg Klippe in Pennsylvania is Middle Ordovician (Lash and Drake, 1984; Lash, 1986; Ganis, 2005), not Late Ordovician as depicted by Hiscott (1984). Thus, across the Appalachians it appears that only the region shielded by the New York Promontory is missing a Middle Ordovician foreland deposit, and several localities preserve both Middle and Late Ordovician forelands. Although this has previously been suggested to reflect diachronous pro-foreland development, geochronologic refinements to both these deposits and the Ordovician timescale in general demonstrate that the Middle and Late Ordovician basin deposits are separated by $\sim 15$ million years, and consequently we prefer a model that permits two separate basin-forming events.

\section{Geochronology and Provenance of Late Ordovician K-Bentonites and Sedimentary Rocks}

Zircon from seven K-bentonite beds in the Trenton Group, interpreted as an air-fall ash deposits were dated with CA-IDTIMS. The stratigraphic position of these K-bentonite beds is shown in figure 4 and the ages are ordered stratigraphically in figure 8. Five grains from the Sherman Falls K-bentonite bed, $14.5 \mathrm{~m}$ from the base of the Trenton Group in the Flat Creek Formation at Canajoharie Creek, yielded a weighted mean date of $452.63 \pm 0.06 \mathrm{Ma}$ (fig. 8). This date provides a new constraint on the end of the $\delta^{13} \mathrm{C}$ excursion in the Glen Falls Limestone and the beginning of the C. americanus graptolite zone and the Katian stage (fig. 4). The $\delta^{13} \mathrm{C}$ excursion in the Glen Falls Limestone of the Trenton Group has been correlated with the global Guttenberg carbon isotope excursion (GICE) (Barta and others, 2007; Bergström and others, 2010; Metzger and others, 2014). Correlations with the Glen Falls Limestone and the rest of the Trenton Group can be refined with $\delta^{13} \mathrm{C}$ chemostratigraphy, as the peak of the positive excursion occurs in the Napanee Formation, with values declining to below +1 permil in the King Falls Formation and not returning to 0\%o until the Sugar River Limestone. Mitchell and others (1994) suggested that the Sugar River Limestone passes basin-ward to a marine unconformity that resulted from sediment starvation during transgression and that much of the upper Trenton Group is missing at Canajoharie Creek. Instead, our data suggest that the Glen Falls Limestone represents most of the Trenton Group, albeit very condensed. The $452.63 \pm 0.06 \mathrm{Ma}$ age constraint on the end of the GICE is $\sim 500$ thousand years older than previous estimates and compresses the duration of the GICE to well under 1 million years.

A stratigraphically higher bed at $37.5 \mathrm{~m}$ in Chuctanunda Creek, which can be correlated with a K-bentonite bed at $55.2 \mathrm{~m}$ from the base of the Trenton Group at Canajoharie Creek (Delano and others, 1994), yielded a weighted mean date of $451.71 \pm 0.13 \mathrm{Ma}$ based on eight grains (fig. 8). This date provides a lower constraint on the end of the $C$. americanus graptolite zone. An upper constraint on the end of the C. americanus zone and constraints on the O. ruedemanni zone are provided by the Manheim ash that was sampled in three localities (Manheim ash, F1302_1.8, and F1301_2.8) and yielded weighted mean dates between $451.62 \pm 0.11$ and $451.26 \pm 0.11 \mathrm{Ma}$ 
(fig. 8). We take the youngest date to be the most reliable because we interpret the spread of older dates to reflect inheritance of zircon that formed just prior to eruption. The effect of recent inheritance is most evident in Nowadaga B1X, which is from the overlying C. spiniferus zone and yielded an older, out of sequence age. This insidious Taconic inheritance can also be seen in CL images in which cores yielded slightly older dates than rims (fig. 8).

In the stratigraphically highest sample from the Indian Castle Formation of the Trenton Group (sample W1204_14.8, fig. 4), six grains were dated with U-Pb CAIDTIMS at $450.71 \pm 0.20 \mathrm{Ma}$ (fig. 8). This date is slightly younger than the 453 to 451 Ma ages previously reported from the Trenton Group and its equivalents (Sell and others, 2015). The $450.71 \pm 0.20 \mathrm{Ma}$ date on the upper Indian Castle Formation provides a maximum age constraint on the overlying syn-orogenic flysch of the Frankfort and Schenectady formations, which were deposited during extensive magmatism in the Bronson Hill arc (Karabinos and others, 2017).

The Trenton Group ashes also contain inherited cores with dates between 1400 and $900 \mathrm{Ma}$ with most close to $1000 \mathrm{Ma}$. Most cores are surrounded by CL black rims, which are interpreted to represent the volcanic component and were dated by LA-ICPMS at $\sim 450 \mathrm{Ma}$ (fig. 7). The dominance of Grenville age (circa 1250-1000 Ga) zircon within these samples, rather than the Neoproterozoic zircon that dominates peri-Gondwanan terranes (Macdonald and others, 2014) suggests that the Trenton ashes erupted through Laurentian crust. Delano and others (1990) demonstrated that the xenocrysts included garnet and that these were also inherited from a Precambrian protolith, as Ar-Ar analyses on feldspars yielded a Precambrian age, consistent with eruption depths of $<5$ to $10 \mathrm{~km}$. These relatively shallow depths suggest that if the Trenton Group ashes were sourced from the Bronson Hill arc, then it was from portions of Laurentian crust that were structurally above the present exhumed exposures of the Bronson Hill arc that have been eroded. Farther south, it appears that a west-dipping subduction zone had nucleated off of Laurentian crust in Connecticut by the Late Ordovician (Sevigny and Hanson, 1993; Sevigny and Hanson, 1995; Walsh and others, 2004; Aleinikoff and others, 2007; Chu and others, 2016). Xenocrystic zircon in the Brookfield plutonic suite match both the age of eruption (circa $450 \mathrm{Ma}$ ) and xenocrystic inheritance (circa 1000-1400 Ma) of the Trenton Group. In the Killingworth Dome, gneisses were dated with U-Pb SHRIMP on zircon at $451 \pm 5$ and $456 \pm 6 \mathrm{Ma}$, and $\mathrm{Pb}$ and $\varepsilon \mathrm{Nd}$ data suggest that these gneisses formed via the mixture of Laurentian and Ganderian crust (Aleinikoff and others, 2007). We suggest these gneisses formed after the accretion of peri-Gondwanan fragments to the Laurentian margin in an east-facing composite arc (fig. 12).

\section{The Taconic Orogeny and Ordovician Basin Formation in New England}

The first sedimentological evidence for the transformation of the Laurentian margin from a passive to an active margin includes the appearance of debrites in the Early Ordovician Poultney Formation and its equivalents in Vermont (Landing, 2012), and an increase in subsidence (fig. 10) (Washington and Chisick, 1994). An Early to Middle Ordovician increase in subsidence has also been documented in the southern Appalachians (Shanmugam and Lash, 1982). Early Ordovician subsidence coincides with collision of the Moretown terrane with peri-Laurentian fragments creating a composite ribbon continent (Macdonald and others, 2014; Bosbyshell and others, 2015) and formation of suprasubduction zone ophiolites (Dunning and Krogh, 1985). The ophiolites and composite ribbon continent were obducted onto the Laurentian margin between 470 and $460 \mathrm{Ma}$ (Dallmeyer and Williams, 1975; Waldron and van Staal, 2001). This event appears to be associated with the appearance of juvenile $\varepsilon \mathrm{Nd}$ values on the Laurentian margin (fig. 5). On the Laurentian platform, Dix and Rodhan (2006) documented seismites and syn-sedimentary faulting in the Early to 
Middle Ordovician Carillon Formation in Québec, which is equivalent to the Providence Island Formation in Vermont. This succession is also correlative with the Middle Ordovician Saint-Daniel mélange in southern Québec, which formed during the obduction of the Thetford Mines ophiolite (Schroetter and others, 2006).

The Early to Middle Ordovician Knox unconformity has previously been attributed to a peripheral bulge of a Middle Ordovician foreland basin (Jacobi, 1981; Quinlan and Beaumont, 1984; Knight and others, 1991). The Knox unconformity is also broadly correlative with shoaling in the Indian River Formation (fig. 11), which is suggested by the appearance of trace fossils (Landing, 2012). 466 to 464 Ma ashes on the Laurentian margin in both the Indian River Formation in New England and the Table Point Group in Newfoundland coincide with a late pulse of magmatism in both the Shelburne Falls arc and Notre Dame arc that we attribute to break-off of an east-dipping slab. Along with uplift from a flexural bulge, we suggest the Knox unconformity could be due to increased buoyancy associated with slab break-off (Buiter and others, 2002; Duretz and others, 2011). Slab break-off could also provide a new explanation for $\mathrm{Cu}-\mathrm{Pb}-\mathrm{Zn}$ mineralization associated with the Knox unconformity in the southern Appalachians (Kyle, 1976; Mussman and Read, 1986) and Vermont (Foley and others, 1995). Middle Ordovician slab break-off magmatism could also account for mafic volcanism on the Hamburg klippe of eastern Pennsylvania (Lash, 1986) and in Middle to Upper Ordovician strata at Starks Knob in New York (Landing and others, 2003).

Dix and others (2013) proposed that the $\sim 462$ to 456 Ma Chazy Group was deposited in a pro-foreland basin. The Darriwillian to Sandbian Chazy Group was deposited at the same time as chert and black shale in the Mount Merino Formation of the Taconic allochthon (fig. 11), which records an apparent deepening. These strata are also coeval with the Partridge Formation, which overlies volcanic rocks in the Bronson Hill arc (Moench and Aleinikoff, 2003), and contains Laurentian-derived detrital zircon (Karabinos and others, 2017). After break-off of the east-dipping slab under the composite ribbon terrane, by $455 \mathrm{Ma}$, polarity of the subduction zone reversed and marginal basins were created on top of and within the Bronson Hill arc (Karabinos and others, 2017), and on top of the Thetford Mines ophiolite in Québec (Schroetter and others, 2006; Tremblay and Pinet, 2016). Thus, after initial loading in a pro-foreland basin, subsidence accommodating the Chazy Group and Mount Merino Formation could also be explained by post-orogenic collapse after slab reversal, analogous to modern extension in the southwestern Okinawa Trough (Clift and others, 2003). Importantly, no geochemical evidence was observed for 462 to $456 \mathrm{Ma}$ foreland deposits in the Taconic allochthon of New York and Vermont that would suggest a proximal load (figs. 9B and 9C).

Central to the model of diachronous development of a single pro-foreland basin (Rowley and Kidd, 1981; Bradley and Kusky, 1986; Bradley, 1989; Lavoie, 1994; Lehmann and others, 1995) is that the Late Ordovician 'Mohawkian' foreland deposits in New York formed in the same tectonic setting as the Middle Ordovician foreland deposits of Newfoundland. However, the distinction of a second Late Ordovician foreland basin in Newfoundland (Quinn and others, 1999) above the Middle Ordovician foreland deposits of the Table Head Group (Stenzel and others, 1990) brings this correlation into question. Additionally, on the Gaspé Peninsula of northern Québec, both Darriwilian flysch of the Tourelle Formation and Late Ordovician flysch of the Cloridorm Formation (Enos, 1969; Hiscott, 1978; Hiscott, 1984) are present, testifying to multiple events. In the Hamburg Klippe of Pennsylvania Middle Ordovician flysch of the Dauphin Formation (Lash and Drake, 1984; Lash, 1986; Ganis, 2005) is succeeded by Late Ordovician foreland deposits of the Martinsburg shale (Shanmugam and Lash, 1982). Thus, we suggest that Laurentian foreland basins record multiple discrete 
events instead of the progression of a single pro-foreland load (fig. 12). Importantly, these Middle and Late Ordovician flysch deposits bracket the timing of slab break-off and reversal in the hinterland (Karabinos and others, 2017; but see Tremblay and Pinet, 2016, for an alternative view). The initiation of subduction under Laurentia prior to $455 \mathrm{Ma}$ further accounts for Ordovician dynamic subsidence in the Michigan Basin (Coakley and Gurnis, 1995).

The Taconic orogenic cycle ended with circa 453 to 451 Ma sinistral oblique thrusting that produced the Utica foreland. This episode is broadly correlative with the Quimby-sequence magmatism in northern New England (Moench and Aleinikoff, 2003), and circa 456 to 445 Ma plutonic rocks in Connecticut, which formed on the Laurentian margin above a west-dipping slab (Sevigny and Hanson, 1993; Sevigny and Hanson, 1995; Walsh and others, 2004; Aleinikoff and others, 2007; Chu and others, 2016). It is unclear what exactly drove Late Ordovician tectonism in New England, but it may have been associated with shallowing subduction angle and increased compression (Jacobi and others, 2016, 2017; Jacobi and Mitchell, 2016). This is consistent with the apparent westward migration of magmatism in western Connecticut (Karabinos and others, 2017).

It has been proposed that pro- and retro-forelands can be distinguished on a plot of subsidence through time with convex- and concave-upward curves, respectively (Naylor and Sinclair, 2008). Our subsidence analysis would appear to be more consistent with a convex-upward, Late Ordovician pro-foreland trend (fig. 10); however, the 30 million year duration of this trend is much too long to attribute to a single loading event; New York was not in a peripheral position of the load until the Late Ordovician, and subsidence continued after $450 \mathrm{Ma}$, so the curve would have a different appearance if extended into the Silurian (Brett and others, 1990). Additionally, retro-foreland basins can have subsidence histories that temporarily appear like pro-foreland basins due to an increase in either the plate velocity or accretionary flux (Sinclair and Naylor, 2012).

Recently, harkening back to pre-plate tectonics conceptions of sequence stratigraphy (Sloss, 1963), macro-stratigraphic analyses have been used to ascribe these sequences to global eustasy (Peters, 2006; Meyers and Peters, 2011). For example, it has previously been suggested that the Knox unconformity, represented by the Beekmantown Group-Chazy Group unconformity, is a product of global eustasy related to the Sauk-Tippecanoe sequence boundary (Sloss, 1963; Landing, 2012). Although Landing (2012) acknowledges that the sub-Black River Group and subTrenton Group unconformities were driven by the Taconic orogeny, he attributes other Cambrian to Ordovician base-level changes in New England to global eustasy; however, without high-latitude ice-sheets, which did not exist until the Middle to Late Ordovician, it is unclear how changes in spreading rate or the mean age of the seafloor could produce significant sea-level change at this timescale (Rowley, 2002). We propose that the major Ordovician sequence boundaries in New England were driven by Taconic tectonism and that the Sauk-Tippecanoe sequence boundary itself is a product of plate reorganization and the development of subduction beneath Laurentia, analogous to the effect of Cretaceous dyanamic subsidence in the midcontinent due to Farallon Plate (Mitrovica and others, 1989). The strong imprint of Taconic tectonism on the sequence stratigraphic record of New England, and the broad correlation of these sequences into the mid-continent, suggests that great caution should be used when interpreting Paleozoic stratigraphy as a record of global sea level.

CONCLUSIONS

Geochronology from the hinterland of the Taconic orogeny in New England demonstrates that the peri-Gondwanan Moretown terrane collided with periLaurentian fragments by $475 \mathrm{Ma}$, and that both were obducted on the Laurentian 
margin by $465 \mathrm{Ma}$; yet, the classic Katian Taconic foreland in the Mohawk Valley formed between $\sim 454$ and $448 \mathrm{Ma}$. Thus, we propose that Ordovician strata on Laurentia formed in separate basin-forming events as composite basins. Ordovician basin formation on Laurentia is marked by an Early Ordovician increase in subsidence followed by the Middle Ordovician Knox unconformity, deposition of the Chazy Group between $\sim 462$ and $456 \mathrm{Ma}$, and the Black River and Trenton Groups between $\sim 454$ and $448 \mathrm{Ma}$. Our new U-Pb CA-IDTIMS zircon dates on the Indian River Formation indicate that arc magmatism was already established near the Laurentian margin by circa $466 \mathrm{Ma}$. Further, shoaling in the Indian River Formation is broadly coincident with slab break-off and foreland basin formation in eastern Canada and the southern Appalachians. Nd isotopic data on slate in the Giddings Brook slice demonstrate that juvenile volcanic detritus had begun to weather from the hinterland and was deposited on the Laurentian margin by this time. It is unclear what drove subsidence between $\sim 462$ and $456 \mathrm{Ma}$ to accommodate the Chazy Group and Mount Merino Formation, but this interval corresponds with a magmatic quiescence and basin formation in the hinterland, perhaps due to extension associated with slab reversal. By $453 \mathrm{Ma}$, a flare-up in the arc that fringed the Laurentian margin, which may have been related to shallowing of the subduction angle or accretion, accompanied shortening and the repetitive eruption of ashes that incorporated xenoliths derived from Laurentian basement. Our new geochronology on ashes in the Trenton Group suggests that these ashes were sourced either from the Quimby Sequence in New Hampshire and Massachusetts, or from multiple magmatic suites in Connecticut where there is an apparent westward migration of magmatism. Thus, the classic Taconic basins of New York formed in a retro-foreland basin, and not in a pro-foreland basin as previously suggested. This work highlights the advantage of integrating the foreland and hinterland when interrogating an orogeny. Particularly we have related distinct Ordovician tectonic events in the hinterland with the stratigraphic record of the Laurentian margin. Finally, we suggest that the major Ordovician stratigraphic sequences of North America are the product of tectonic subsidence and plate reorganization in the Appalachian hinterland rather than global eustasy.

\section{ACKNOWLEDGEMENTS}

We thank Charles Mitchell, Nizhoni O'Connell, William Thompson-Butler, Joe Schaffer, and Dave Johnston for help in the field; Sarah Dendy, Camille Dwyer, Sasha Breus, and André Poirier for help in the lab; Dwight Bradley and Bill Kidd for an introduction to the Mohawk Valley; Mark Schmitz and Dan Schrag for the use of their labs; and Alexandra Edwards for preparation of the CL files for the online supplement. Reviews by John Dewey and Alain Tremblay improved the manuscript.

APPENDIX

\section{LA-ICPMS Methods}

Zircon grains were separated from rocks using standard techniques and annealed at $900{ }^{\circ} \mathrm{C}$ for 60 hours in a muffle furnace. Grains were randomly selected for the detrital zircon samples. Sharply faceted grains were selected for the volcanic ash samples. Grains were mounted in epoxy and polished until their centers were exposed. Cathodoluminescence (CL) images were obtained with a JEOL JSM-1300 scanning electron microscope and Gatan MiniCL (fig. 7). Zircon was analyzed by laser ablation inductively coupled plasma mass spectrometry (LA-ICPMS) using a ThermoElectron X-Series II quadrupole ICPMS and New Wave Research UP-213 Nd:YAG UV (213 nm) laser ablation system. In-house analytical protocols, standard materials, and data reduction software were used for acquisition and calibration of U-Pb dates and a suite of high field strength elements (HFSE) and rare earth elements (REE). Zircon was 
ablated with a laser spot of $25 \mu \mathrm{m}$ wide using fluence and pulse rates of $5 \mathrm{~J} / \mathrm{cm}^{2}$ and 10 $\mathrm{Hz}$, respectively, during a 45 second analysis (15 sec gas blank, $30 \mathrm{sec}$ ablation) that excavated a pit $\sim 25 \mu \mathrm{m}$ deep. Ablated material was carried by a $1.2 \mathrm{~L} / \mathrm{min} \mathrm{He}$ gas stream to the nebulizer flow of the plasma. Quadrupole dwell times were $5 \mathrm{~ms}$ for $\mathrm{Si}$ and $\mathrm{Zr}, 200 \mathrm{~ms}$ for ${ }^{49} \mathrm{Ti}$ and ${ }^{207} \mathrm{~Pb}, 80 \mathrm{~ms}$ for ${ }^{206} \mathrm{~Pb}, 40 \mathrm{~ms}$ for ${ }^{202} \mathrm{Hg},{ }^{204} \mathrm{~Pb},{ }^{208} \mathrm{~Pb},{ }^{232} \mathrm{Th}$, and ${ }^{238} \mathrm{U}$ and $10 \mathrm{~ms}$ for all other HFSE and REE; total sweep duration is $950 \mathrm{~ms}$. Background count rates for each analyte were obtained prior to each spot analysis and subtracted from the raw count rate for each analyte. For concentration calculations, background-subtracted count rates for each analyte were internally normalized to ${ }^{29} \mathrm{Si}$ and calibrated with respect to NIST SRM-610 and -612 glasses as the primary standards. Ablation pits that appear to have intersected glass or mineral inclusions were identified based on Ti and P signal excursions, and associated sweeps were discarded. U-Pb dates from these analyses are considered valid if the $\mathrm{U}-\mathrm{Pb}$ ratios appear to have been unaffected by the inclusions. Signals at mass 204 were normally indistinguishable from zero following subtraction of mercury backgrounds measured during the gas blank $\left(<1000 \mathrm{cps}{ }^{202} \mathrm{Hg}\right)$, and thus dates are reported without common Pb correction. Rare analyses that appear contaminated by common $\mathrm{Pb}$ were rejected based on mass 204 greater than baseline. Temperature was calculated from the Ti-in-zircon thermometer (Watson and others, 2006). Because there are no constraints on the activity of $\mathrm{TiO}_{2}$ in the source rocks, an average value in crustal rocks of 0.8 was used.

Data were collected in 13 experiments from November 2011 to January 2016 (table A1, http://earth.geology.yale.edu/ ajs/SupplementaryData/2017/Macdonald). For $\mathrm{U}-\mathrm{Pb}$ and ${ }^{207} \mathrm{~Pb} /{ }^{206} \mathrm{~Pb}$ dates, instrumental fractionation of the backgroundsubtracted ratios was corrected and dates were calibrated with respect to interspersed measurements of zircon standards and reference materials. The primary standard Plešovice zircon (Sláma and others, 2008) was used to monitor time-dependent instrumental fractionation based on two analyses for every 10 analyses of unknown zircon. A secondary correction to the ${ }^{206} \mathrm{~Pb} /{ }^{238} \mathrm{U}$ dates was made based on results from a combination of the zircon standards that were dated at Boise State University (unpublished data): Seiland (530 Ma) and Zirconia (327 Ma), Temora (417 Ma), and FC1 (1098 Ma). These standards were treated as unknowns and measured once for every 10 analyses of unknown zircon. These results showed a linear age bias of up to several percent that is related to the ${ }^{206} \mathrm{~Pb}$ count rate. The secondary correction is thought to mitigate matrix-dependent variations due to contrasting compositions and ablation characteristics between the Plešovice zircon and other standards (and unknowns).

Radiogenic isotope ratio and age error propagation for all analyses includes uncertainty contributions from counting statistics and background subtraction. Because the detrital zircon analyses are interpreted individually, uncertainties from the standard calibrations are propagated into the errors on each date. These uncertainties are the local standard deviations of the polynomial fits to the interspersed primary standard measurements versus time for the time-dependent, relatively larger U-Pb fractionation factor, and the standard errors of the means of the consistently timeinvariant and smaller ${ }^{207} \mathrm{~Pb} /{ }^{206} \mathrm{~Pb}$ fractionation factor. These uncertainties are $1.3-$

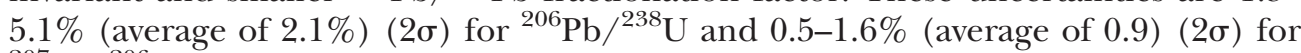
${ }^{207} \mathrm{~Pb} /{ }^{206} \mathrm{~Pb}$. For the volcanic ash samples and detrital zircon with multiple analyses from the same grains, weighted mean dates are calculated on equivalent dates (that is, POF $>0.05$ ) using Isoplot 3.0 (Ludwig, 2003) from errors on individual dates that do not include the standard calibration uncertainties. However, errors on weighted mean dates include the standard calibration uncertainties within each experiment and are given at $2 \sigma$. 
Age interpretations are based on ${ }^{207} \mathrm{~Pb} /{ }^{206} \mathrm{~Pb}$ dates for analyses with ${ }^{207} \mathrm{~Pb} /{ }^{206} \mathrm{~Pb}$ dates $>1000 \mathrm{Ma}$. Analyses with $>20 \%$ positive discordance and $>10 \%$ negative discordance are not considered. The ${ }^{206} \mathrm{~Pb} /{ }^{238} \mathrm{U}$ dates are used for analyses with ${ }^{207} \mathrm{~Pb} /{ }^{206} \mathrm{~Pb}$ dates $<1000 \mathrm{Ma}$. Errors on the dates from individual analyses are given at $2 \sigma$. Results are shown in table A1, http:/ / earth.geology.yale.edu/ ajs/SupplementaryData/2017/ Macdonald.

\section{CA-IDTIMS Methods}

$\mathrm{U}-\mathrm{Pb}$ dates were obtained by the chemical abrasion-isotope dilution thermal ionization mass spectrometry (CA-IDTIMS) method from analyses composed of single zircon grains or fragments of grains (table A2; http://earth.geology.yale.edu/ ajs/ SupplementaryData/2017/Macdonald), modified after Mattinson (2005). Annealed zircon was removed from the epoxy mounts for dating based on CL images and LA-ICPMS data collected from some of the samples. Single grains or fragments were then transferred to $3 \mathrm{ml}$ Teflon PFA beakers and loaded into $300 \mu \mathrm{l}$ Teflon PFA microcapsules. Fifteen microcapsules were placed in a large-capacity Parr vessel and the grains or fragments partially dissolved in $120 \mu \mathrm{l}$ of $29 \mathrm{M} \mathrm{HF}$ for 12 hours at $180^{\circ} \mathrm{C}$. The contents of the microcapsules were returned to $3 \mathrm{ml}$ Teflon PFA beakers, HF removed, and the residual grains or fragments immersed in $3.5 \mathrm{M} \mathrm{HNO}_{3}$, ultrasonically cleaned for an hour, and fluxed on a hotplate at $80^{\circ} \mathrm{C}$ for an hour. The $\mathrm{HNO}_{3}$ was removed and grains or fragments were rinsed twice in ultrapure $\mathrm{H}_{2} \mathrm{O}$ before being reloaded into the $300 \mu \mathrm{l}$ Teflon PFA microcapsules (rinsed and fluxed in $6 \mathrm{M} \mathrm{HCl}$ during sonication and washing of the grains) and spiked with one of three tracer solutions described below. Zircon was dissolved in Parr vessels in $120 \mu \mathrm{l}$ of $29 \mathrm{M} \mathrm{HF}$ with a trace of $3.5 \mathrm{M} \mathrm{HNO}_{3}$ at $220^{\circ} \mathrm{C}$ for 48 hours, dried to fluorides, and re-dissolved in $6 \mathrm{M} \mathrm{HCl}$ at $180{ }^{\circ} \mathrm{C}$ overnight. $\mathrm{U}$ and $\mathrm{Pb}$ were separated from the zircon matrix using an HCl-based anion-exchange chromatographic procedure (Krough, 1973), eluted together and dried with $2 \mu \mathrm{l}$ of $0.05 \mathrm{~N} \mathrm{H}_{3} \mathrm{PO}_{4}$.

$\mathrm{Pb}$ and $\mathrm{U}$ were loaded on a single outgassed Re filament in $5 \mu$ l of a silica-gel/ phosphoric acid mixture (Gerstenberger and Haase, 1997), and $\mathrm{U}$ and $\mathrm{Pb}$ isotopic measurements made on a GV Isoprobe-multicollector thermal ionization mass spectrometer equipped with an ion-counting Daly detector. Pb isotopes were measured by peak-jumping all isotopes on the Daly detector for 100 to 160 cycles, and corrected for $0.16 \pm 0.03$ or $0.18 \pm 0.03 \% /$ a.m.u ( 1 sigma error) mass fractionation for all samples except one. For one sample that used the EARTHTIME ET2535 tracer solution, fractionation was determined from the measured ${ }^{202} \mathrm{~Pb} /{ }^{205} \mathrm{~Pb}$. Transitory isobaric interferences due to high-molecular weight organics, particularly on ${ }^{204} \mathrm{~Pb}$ and ${ }^{207} \mathrm{~Pb}$, disappeared within approximately 30 cycles, while ionization efficiency averaged $10^{4}$ $\mathrm{cps} / \mathrm{pg}$ of each $\mathrm{Pb}$ isotope. Linearity (to $\geq 1.4 \times 10^{6} \mathrm{cps}$ ) and the associated deadtime correction of the Daly detector were monitored by repeated analyses of NBS982, and have been constant since installation. Uranium was analyzed as $\mathrm{UO}_{2}{ }^{+}$ions in static Faraday mode on $10^{11} \mathrm{ohm}$ or $10^{12} \mathrm{ohm}$ resistors for $200-300$ cycles, and corrected for isobaric interference of ${ }^{233} \mathrm{U}^{18} \mathrm{O}^{16} \mathrm{O}$ on ${ }^{235} \mathrm{U}^{16} \mathrm{O}^{16} \mathrm{O}$ with an ${ }^{18} \mathrm{O} /{ }^{16} \mathrm{O}$ of 0.00206 . Ionization efficiency averaged $20 \mathrm{mV} / \mathrm{ng}$ of each $\mathrm{U}$ isotope. $\mathrm{U}$ mass fractionation was corrected using the known ${ }^{233} \mathrm{U} /{ }^{235} \mathrm{U}$ ratio of the tracer solutions.

Three tracer solutions were used, as indicated in table A2, http://earth.geology. yale.edu/ ajs/SupplementaryData/2017/Macdonald. EARTHTIME ET535 (Condon and others, 2015) was used in six samples with a calibration of ${ }^{235} \mathrm{U} /{ }^{205} \mathrm{~Pb}=100.233$, ${ }^{233} \mathrm{U} /{ }^{235} \mathrm{U}=0.99506$, and ${ }^{205} \mathrm{~Pb} /{ }^{204} \mathrm{~Pb}=11196$. EARTHTIME ET2535 (Condon and others, 2015) was used in one sample with a calibration of ${ }^{202} \mathrm{~Pb} /{ }^{205} \mathrm{~Pb}=0.99924$, ${ }^{235} \mathrm{U} /{ }^{205} \mathrm{~Pb}=100.233,{ }^{233} \mathrm{U} /{ }^{235} \mathrm{U}=0.99506$, and ${ }^{205} \mathrm{~Pb} /{ }^{204} \mathrm{~Pb}=8474$. The Boise State University tracer solution was used in six samples with a calibration of ${ }^{235} \mathrm{U} /{ }^{205} \mathrm{~Pb}=$ 77.93 and ${ }^{233} \mathrm{U} /{ }^{235} \mathrm{U}=1.007066$. CA-IDTIMS U-Pb dates and uncertainties were 
calculated using the algorithms of Schmitz and Schoene (2007) and U decay constants recommended by Jaffey and others (1971). ${ }^{206} \mathrm{~Pb} /{ }^{238} \mathrm{U}$ ratios and dates were corrected for initial ${ }^{230} \mathrm{Th}$ disequilibrium using a $\mathrm{Th} / \mathrm{U}$ [magma $]=3.0 \pm 0.3$ using the algorithms of Crowley and others $(2007)$, resulting in an increase in the ${ }^{206} \mathrm{~Pb} /{ }^{238} \mathrm{U}$ dates of $\sim 0.09 \mathrm{Ma}$. All common $\mathrm{Pb}$ in analyses was attributed to laboratory blank and subtracted based on the measured laboratory $\mathrm{Pb}$ isotopic composition and associated uncertainty. U blanks are estimated at $0.075 \mathrm{pg}$.

Weighted mean ${ }^{206} \mathrm{~Pb} /{ }^{238} \mathrm{U}$ dates were calculated from equivalent dates (that is, POF $>0.05$ ) using Isoplot 3.0 (Ludwig, 2003). Errors on the weighted mean dates are given as $\pm \mathrm{x} / \mathrm{y} / \mathrm{z}$, where $\mathrm{x}$ is the internal error based on analytical uncertainties only, including counting statistics, subtraction of tracer solution, and blank and initial common $\mathrm{Pb}$ subtraction, y includes the tracer calibration uncertainty propagated in quadrature, and $\mathrm{z}$ includes the ${ }^{238} \mathrm{U}$ decay constant uncertainty propagated in quadrature. Internal errors should be considered when comparing our dates with ${ }^{206} \mathrm{~Pb} /{ }^{238} \mathrm{U}$ dates from other laboratories that used the same EARTHTIME tracer solution or a tracer solution that was cross-calibrated using EARTHTIME gravimetric standards. Errors including the uncertainty in the tracer calibration should be considered when comparing our dates with those derived from other geochronological methods using the U-Pb decay scheme (for example, LA-ICPMS). Errors including uncertainties in the tracer calibration and ${ }^{238} \mathrm{U}$ decay constant (Jaffey and others, 1971) should be considered when comparing our dates with those derived from other decay schemes (for example, ${ }^{40} \mathrm{Ar} /{ }^{39} \mathrm{Ar},{ }^{187} \mathrm{Re}^{-187} \mathrm{Os}$ ). Errors for weighted mean dates and dates from individual grains are given at $2 \sigma$. Results are shown in table A2, http:/ / earth.geology. yale.edu/ ajs/SupplementaryData/2017/Macdonald.

\section{Whole Rock Geochemistry Methods}

One kilogram samples of sedimentary rocks were crushed using a stainless steel roller mill to less than $1 \mathrm{~mm}$ particles. 200-gram aliquots of powders were prepared with a tungsten carbide shatter box. These large masses were intended to ensure that the samples were representative of the whole rock (Clanton and Fletcher, 1976). Twenty-five gram splits of those powders were analyzed with x-ray flourescence (XRF) by Dr. S. T. Ahmedali, Geochemical Laboratories, McGill University. Precision of these analyses was assessed by replicate analyses of shale from the Austin Glen Formation. Aliquots of this shale working-standard were from the same 500-grams of powder and were not known to the analyst. The results are listed in the Appendix. Sample preparation for Taconic K-bentonites followed a similar procedure used for sedimentary rocks. Twenty-five gram splits of powders were analyzed with XRF by Rick Conrey and Diane Johnson Cornelius, GeoAnalytical Laboratory, Washington State University. Results are shown in table A3, http://earth.geology.yale.edu/ ajs/Supplementary Data/2017/Macdonald.

\section{Nd Isotope Methods}

Weathered edges of each collected sample were removed using a rock saw, a small fragment was cut to make a thin section, and the remainder was homogenized with a SPEX 8500 shatterbox using a tungsten carbide grinding container. Each powdered sample was ignited at $\sim 1000^{\circ} \mathrm{C}$ to remove all volatiles and organic matter, and then $\sim$ $0.3 \mathrm{~g}$ was weighed into a $5 \mathrm{~mL}$ Teflon beaker, spiked with enriched ${ }^{150} \mathrm{Nd}^{149} \mathrm{Sm}$ tracer, and dissolved under pressure with a $\mathrm{HF}^{-} \mathrm{HNO}_{3}$ mixture. The resulting solutions were evaporated and dissolved in an $\sim 6 \mathrm{~N}$ aqua-regia $\left(3: 1, \mathrm{HCl}-\mathrm{HNO}_{3}\right)$, and then evaporated and dissolved again in $6 \mathrm{~N} \mathrm{HCl}$. Pure $\mathrm{Nd}$ and Sm extracts of each sample were separated via gravity driven column chromatography in a three-stage process. First, Fe was removed by passing the sample through columns filled with 200-400 mesh AG1X8 anion exchange resin. Second, the REE component was concentrated by twice passing 
the sample through columns filled with Eichrom TRU Resin SPS 50-100 $\mu \mathrm{m}$. Third, the $\mathrm{Sm}$ and $\mathrm{Nd}$ fractions were purified by passing the samples through columns filled with $\sim 600 \mathrm{mg}$ of Eichrom LN Resin 50-100 $\mathrm{mm}$. Both Nd and Sm separates were evaporated and redissolved into $3 \mathrm{~mL}$ of $2 \% \mathrm{HNO}_{3}$ for analysis on a $\mathrm{Nu}$ Plasma II multicollector ICP-MS at the Geotop laboratory affiliated with McGill University. Before analysis all samples were redissolved with $2 \% \mathrm{HNO}_{3}$ to between $20-40 \mathrm{ppb}$ to ensure samples were run between 2-20 V. In order to minimize the formation of $\mathrm{NdO}$ $\mathrm{N}_{2}$ gas was injected $(1 \mathrm{~mL} / \mathrm{min})$ in the Aridus II desolvating membrane. Isotopic ratios of ${ }^{142} \mathrm{Nd} /{ }^{144} \mathrm{Nd},{ }^{143} \mathrm{Nd} /{ }^{144} \mathrm{Nd},{ }^{145} \mathrm{Nd} /{ }^{144} \mathrm{Nd},{ }^{148} \mathrm{Nd} /{ }^{144} \mathrm{Nd},{ }^{150} \mathrm{Nd} /{ }^{144} \mathrm{Nd}$, and ${ }^{149} \mathrm{Sm} /$ ${ }^{152} \mathrm{Sm}$ were measured for each sample. Replicate measurements of the Nd isotopic reference JNdi-1 yielded values within error of the value obtained by Tanaka and others $(2000)\left({ }^{143} \mathrm{Nd} /{ }^{144} \mathrm{Nd}=0.5121141 \pm \mathrm{d}=0.512\right.$, and measurements of BHVO-2 yielded values within error of the accepted value (Raczek and others, 2003) $\left({ }^{143} \mathrm{Nd} /\right.$ $\left.{ }^{144} \mathrm{Nd}=0.512673 \pm \mathrm{d}=0.51\right)$. For each sample, the ${ }^{147} \mathrm{Sm} /{ }^{144} \mathrm{Nd}$ ratio and $\mathrm{Sm}$ and $\mathrm{Nd}$ concentrations were calculated using these measurements along with the sample and spike masses. The ${ }^{143} \mathrm{Nd} /{ }^{144} \mathrm{Nd}$ and ${ }^{147} \mathrm{Sm} /{ }^{144} \mathrm{Nd}$ ratios and $\mathrm{Sm}$ and $\mathrm{Nd}$ concentrations combined with the approximate depositional age of the sample (discussed above), were used in a Goldstein recalculation to calculate the $\varepsilon N d$ at the time of sedimentation, or initial $\mathrm{Nd}$ isotopic composition. In this calculation, the chondritic reference values used are ${ }^{143} \mathrm{Nd} /{ }^{144} \mathrm{Nd}$ CHUR $=0.512638$ and ${ }^{147} \mathrm{Sm} /{ }^{144} \mathrm{Nd}$ CHUR $=$ 0.1966 , and the decay constant for ${ }^{147} \mathrm{Sm}$ to ${ }^{143} \mathrm{Nd}$ was assumed to be $6.54 \mathrm{E}-12$ (Goldstein, O'nions, and Hamilton, 1984). The reported Sm and Nd concentrations and ${ }^{147} \mathrm{Sm} /{ }^{144} \mathrm{Nd}$ ratios have less than $0.5 \%$ error, corresponding to an error of less than $0.2 \varepsilon N d$ units, and most of the reported $\varepsilon N d$ values have an error of less than 0.2 $\varepsilon N d$ units. Results are shown in table A4, http://earth.geology.yale.edu/ ajs/ SupplementaryData/2017/Macdonald.

\section{Carbonate Carbon and Oxygen Isotope Methods}

Carbonate $\delta^{13} \mathrm{C}$ and $\delta^{18} \mathrm{O}$ data were acquired simultaneously on a VG Optima dual inlet mass spectrometer attached to a VG Isocarb preparation device (Micromass, Milford, MA) in the Harvard University Laboratory for Geochemical Oceanography. Approximately $1 \mathrm{mg}$ micro-drilled samples were reacted in a common, purified $\mathrm{H}_{3} \mathrm{PO}_{4}$ bath at $90{ }^{\circ} \mathrm{C}$. Evolved $\mathrm{CO}_{2}$ was collected cryogenically and analyzed using an in-house reference gas. External error $(1 \sigma)$ from standards was better than \pm 0.1 per mil $(\% o)$ for both $\delta^{13} \mathrm{C}$ and $\delta^{18} \mathrm{O}$. Samples were calibrated to Vienna-Pee Dee Belemnite (V-PDB) using the Cararra Marble standard. Potential memory effect resulting from the common acid-bath system was minimised by increasing the reaction time for dolomite samples. Memory effect is estimated at $<0.1 \%$ based on variability of standards run after dolomite samples. Carbonate $\delta^{13} \mathrm{C}$ and $\delta^{18} \mathrm{O}$ isotopic results are reported in \%o notation relative to V-PDB. Results are shown in table A5, http:// earth.geology.yale.edu/ ajs/SupplementaryData/2017/Macdonald.

\section{REFERENCES}

Adhya, S., ms, 2009, Geochemical fingerprinting of volcanic airfall deposits: a tool in stratigraphic correlation: Albany, New York, State University of New York, Ph.D. thesis, 532 p.

Albani, R., Bagnoli, G., Maletz, J., and Stouge, S., 2001, Integrated chitinozoan, conodont, and graptolite biostratigraphy from the upper part of the Cape Cormorant Formation (Middle Ordovician), western Newfoundland: Canadian Journal of Earth Sciences, v. 38, n. 3, p. 387-409, https://doi.org/10.1139/ e00-081

Aleinikoff, J. N., 2015, New SHRIMP U-Pb zircon ages for felsic Ammonoosuc Volcanics, Northern NH-VT: Geological Society of America Abstracts with Programs, v. 47, p. 41.

Aleinikoff, J. N., Wintsch, R. P., Tollo, R. P., Unruh, D. M., Fanning, C. M., and Schmitz, M. D., 2007, Ages and origins of rocks of the Killingworth dome, south-central Connecticut: Implications for the tectonic evolution of southern New England: American Journal of Science, v. 307, n. 1, p. 63-118, https://doi.org/ $10.2475 / 01.2007 .04$ 
Aleinikoff, J., Ratcliffe, N., and Walsh, G., 2011, Provisional zircon and monazite uranium-lead geochronology for selected rocks from Vermont: US Geological Survey Open-File Report, v. 1309, p. 46.

Allen, P. A., and Allen, J. R., 2013, Basin Analysis: Principles and Application to Petroleum Play Assessment, $3^{\text {rd }}$ Edition: West Sussex, United Kingdom, John Wiley \& Sons, 632 p.

Andersen, C. B., and Samson, S. D., 1995, Temporal changes in Nd isotopic composition of sedimentary rocks in the Sevier and Taconic foreland basins: Increasing influence of juvenile sources: Geology, v. 23, n. 11, p. 983-986, https://doi.org/10.1130/0091-7613(1995)023<0983:TCINIC > 2.3.CO;2

Barta, N. C., Bergström, S., Saltzman, M. R., and Schmitz, B., 2007, First record of the Ordovician Guttenberg $\delta^{13} \mathrm{C}$ excursion (GICE) in New York State and Ontario: local and regional chronostratigraphic implications: Northeastern Geology and Environmental Sciences, v. 29, p. 276-298.

Bergström, S. M., Schmitz, B., Saltzman, M. R., and Huff, W. D., 2010, The Upper Ordovician Guttenberg $\delta{ }^{13} \mathrm{C}$ excursion (GICE) in North America and Baltoscandia: occurrence, chronostratigraphic significance, and paleoenvironmental relationships: Geological Society of America Special Papers, v. 466, p. 37-67, https://doi.org/10.1130/2010.2466(04)

Berry, W. B. N., 1962, Stratigraphy, zonation, and age of Schaghticoke, Deepkill, and Normanskill shales, eastern New York: Geological Society of America Bulletin, v. 73, n. 6, p. 695-718, https://doi.org/ 10.1130/0016-7606(1962)73[695:SZAAOS]2.0.CO;2

Bird, J. M., and Dewey, J. F., 1970, Lithosphere plate-continental margin tectonics and the evolution of the Appalachian orogen: Geological Society of America Bulletin, v. 81, n. 4, p. 1031-1060, https://doi.org/ 10.1130/0016-7606(1970)81 [1031:LPMTAT]2.0.CO;2

Bock, B., McLennan, S. M., and Hanson, G. N., 1994, Rare earth element redistribution and its effects on the neodymium isotope system in the Austin Glen Member of the Normanskill Formation, New York, USA: Geochimica et Cosmochimica Acta, v. 58, n. 23, p. 5245-5253, https://doi.org/10.1016/00167037(94)90308-5

_ 1996, The Taconian orogeny in southern New England: Nd-isotope evidence against addition of juvenile components: Canadian Journal of Earth Sciences, v. 33, n. 12, p. 1612-1627, https://doi.org/ $10.1139 / \mathrm{e} 96-122$

Bock, B., Hurowitz, J. A., McLennan, S. M., and Hanson, G. N., 2004, Scale and timing of Rare Earth Element redistribution in the Taconian foreland of New England: Sedimentology, v. 51, n. 4, p. 885-897, https://doi.org/10.1111/j.1365-3091.2004.00656.x

Bosbyshell, H., Srogi, L., Blackmer, G. C., Schenck, W. S., Mathur, R., and Valencia, V., 2015, The tectono-thermal evolution of the central Appalachian Orogen: Accretion of a peri-Gondwanan (?) Ordovician arc: Field Guides, v. 40, p. 35-59, https://doi.org/10.1130/2015.0040(03)

Bosworth, W., Rowley, D. B., Kidd, W. F. S., and Steinhardt, C., 1988, Geometry and style of post-obduction thrusting in a Paleozoic orogen: The Taconic frontal thrust system: The Journal of Geology, v. 96, n. 2, p. 163-180, https://doi.org/10.1086/629207

Bradley, D., 1989, Taconic plate kinematics as revealed by foredeep stratigraphy, Appalachian orogen: Tectonics, v. 8, n. 5, p. 1037-1049, https://doi.org/10.1029/TC008i005p01037

Bradley, D. C., and Kusky, T., 1986, Geologic evidence for rate of plate convergence during the Taconic arc-continent collision: Journal of Geology, v. 94, n. 5, p. 667-681, https://doi.org/10.1086/629073

Brett, C. E., and Baird, G. C., 2002, Revised stratigraphy of the Trenton Group in its type area, central New York State: Sedimentology and tectonics of a Middle Ordovician shelf-to-basin succession: Physics and Chemistry of the Earth, Parts A/B/C, v. 27, n. 1-3, p. 231-263, https://doi.org/10.1016/S14747065(01)00007-9

Brett, C. E., Goodman, W. M., and LoDuca, S. T., 1990, Sequences, cycles, and basin dynamics in the Silurian of the Appalachian Foreland Basin: Sedimentary Geology, v. 69, n. 3-4, p. 191-244, https://doi.org/ 10.1016/0037-0738(90)90051-T

Brett, K. D., and Westrop, S. R., 1996, Trilobites of the Lower Ordovician (Ibexian) Fort Cassin Formation, Champlain valley region, New York State and Vermont: Journal of Paleontology, v. 70, n. 3, p. 408-427, http://www.jstor.org/stable/1306436

Buiter, S. J. H., Govers, R., and Wortel, M. J. R., 2002, Two-dimensional simulations of surface deformation caused by slab detachment: Tectonophysics, v. 354, n. 3-4, p. 195-210, https://doi.org/10.1016/S00401951(02) 00336-0

Carr, S. D., Easton, R. M., Jamieson, R. A., and Culshaw, N. G., 2000, Geologic transect across the Grenville orogen of Ontario and New York: Canadian Journal of Earth Sciences, v. 37, n. 2-3, p. 193-216, https://doi.org/10.1139/e99-074

Castonguay, S., Kim, J., Thompson, P. J., Gale, M. H., Joyce, N., Laird, J., and Doolan, B. L., 2012, Timing of tectonometamorphism across the Green Mountain anticlinorium, northern Vermont Appalachians: ${ }^{40} \mathrm{Ar} /{ }^{39} \mathrm{Ar}$ data and correlations with southern Québec: Geological Society of America Bulletin, v. 124, n. 3-4, p. 352-367, https://doi.org/10.1130/B30487.1

Cawood, P. A., and Nemchin, A. A., 2001, Paleogeographic development of the east Laurentian margin: Constraints from U-Pb dating of detrital zircons in the Newfoundland Appalachians: Geological Society of America Bulletin, v. 113, n. 9, p. 1234-1246, https://doi.org/10.1130/0016-7606(2001)113<1234: PDOTEL $>2.0 . \mathrm{CO} ; 2$

Chu, X., Ague, J. J., Axler, J. A., and Tian, M., 2016, Taconian retrograde eclogite from northwest Connecticut, USA, and its petrotectonic implications: Lithos, v. 240-243, p. 276-294, https://doi.org/ 10.1016/j.lithos.2015.10.011

Clanton, U. S., and Fletcher, C. R., 1976, Sample size and sampling errors as the source of dispersion in chemical analyses: New York, Pergamon Press, Proceedings Lunar and Planetary Science $7^{\text {th }}$ Conference, Houston, Texas, March 15-19, 1976, v. 2, p. 1413-1428.

Clift, P. D., Schouten, H., and Draut, A. E., 2003, A general model of arc-continent collision and subduction 
polarity reversal from Taiwan and the Irish Caledonides: Geological Society, London, Special Publications, v. 219, p. 81-98, https://doi.org/10.1144/GSL.SP.2003.219.01.04

Coakley, B., and Gurnis, M., 1995, Far-field tilting of Laurentia during the Ordovician and constraints on the evolution of a slab under an ancient continent: Journal of Geophysical Research: Solid Earth, v. 100, n. B4, p. 6313-6327, https://doi.org/10.1029/94JB02916

Coish, R. A., 1997, Rift and ocean floor volcanism from the Late Proterozoic and early Paleozoic of the Vermont Appalachians: Geological Socitey of America, Memoirs, v. 191, p. 129-146, https://doi.org/ $10.1130 / 0-8137-1191-6.129$

Coish, R., Kim, J., Morris, N., and Johnson, D., 2011, Late stage rifting of the Laurentian continent: evidence from the geochemistry of greenstone and amphibolite in the central Vermont Appalachians: Canadian Journal of Earth Sciences, v. 49, n. 1, p. 43-58, https://doi.org/10.1139/e11-013

Condon, D. J., Schoene, B., McLean, N. M., Bowring, S. A., and Parrish, R. R., 2015, Metrology and traceability of $\mathrm{U}-\mathrm{Pb}$ isotope dilution geochronology (EARTHTIME Tracer Calibration Part I): Geochimica et Cosmochimica Acta, v. 164, p. 464-480, https://doi.org/10.1016/j.gca.2015.05.026

Cowan, C. A., and James, N. P., 1993, The interactions of sea-level change, terrigenous-sediment influx, and carbonate productivity as controls on Upper Cambrian Grand Cycles of western Newfoundland, Canada: Geological Society of America Bulletin, v. 105, n. 12, p. 1576-1590, https://doi.org/10.1130/ 0016-7606(1993) 105<1576:TIOSLC>2.3.CO;2

Crowley, J. L., Schoene, B., and Bowring, S. A., 2007, U-Pb dating of zircon in the Bishop Tuff at the millennial scale: Geology, v. 35, n. 12,p. 1123-1126, https://doi.org/10.1130/G24017A.1

Dallmeyer, R. D., and Williams, H., 1975, ${ }^{40} \mathrm{Ar} /{ }^{39} \mathrm{Ar}$ ages from the Bay of Islands metamorphic aureole: Their bearing on the timing of Ordovician ophiolite obduction: Canadian Journal of Earth Sciences, v. 12, n. 9, p. 1685-1690, https://doi.org/10.1139/e75-148

De Souza, S., Tremblay, A., Ruffet, G., Pinet, N., and Murphy, B., 2011, Ophiolite obduction in the Québec Appalachians, Canada- $-{ }^{40} \mathrm{Ar} /{ }^{39} \mathrm{Ar}$ age constraints and evidence for syn-tectonic erosion and sedimentation: Canadian Journal of Earth Sciences, v. 49, n. 1, p. 91-110, https://doi.org/10.1139/e11-037

Delano, J. W., Schirnick, C., Bock, B., Kidd, W. S. F., Heizler, M. T., Putman, G. W., De Long, S. E., and Ohr, M., 1990, Petrology and geochemistry of Ordovician K-bentonites in New York State: Constraints on the nature of a volcanic arc: The Journal of Geology, v. 98, n. 2, p. 157-170, https://doi.org/10.1086/ 629391

Delano, J. W., Tice, S. J., Mitchell, C. E., and Goldman, D., 1994, Rhyolitic glass in Ordovician K-bentonites: A new stratigraphic tool: Geology, v. 22, n. 2, p. 115-118, https://doi.org/10.1130/00917613(1994)022<0115:RGIOKB >2.3.CO;2

Dix, G. R., and Rodhan, Z. A., 2006, A new geological framework for the Middle Ordovician Carillon Formation (uppermost Beekmantown Group, Ottawa Embayment): Onset of Taconic foreland deposition and tectonism within the Laurentian platform interior: Canadian Journal of Earth Sciences, v. 43, n. 9, p. 1367-1387, https://doi.org/10.1139/e06-030

Dix, G. R., Nehza, O., and Okon, I., 2013, Tectonostratigraphy of the Chazyan (Late Middle-Early Late Ordovician) Mixed Siliciclastic-Carbonate Platform, Québec Embayment: Journal of Sedimentary Research, v. 83, n. 6, p. 451-474, https://doi.org/10.2110/jsr.2013.39

Domeier, M., 2016, A plate tectonic scenario for the Iapetus and Rheic oceans: Gondwana Research, v. 36, p. 275-295, https://doi.org/10.1016/j.gr.2015.08.003

Dorais, M. J., Atkinson, M., Kim, J., West, D. P., and Kirby, G. A., 2011, Where is the Iapetus suture in northern New England? A study of the Ammonoosuc Volcanics, Bronson Hill terrane, New Hampshire: Canadian Journal of Earth Sciences, v. 49, n. 1, p. 189-205, https://doi.org/10.1139/e10-108

Dunning, G., and Krogh, T., 1985, Geochronology of ophiolites of the Newfoundland Appalachians: Canadian Journal of Earth Sciences, v. 22, n. 11, p. 1659-1670, https://doi.org/10.1139/e85-174

Duretz, T., Gerya, T. V., and May, D. A., 2011, Numerical modelling of spontaneous slab breakoff and subsequent topographic response: Tectonophysics, v. 502, n. 1-2, p. 244-256, https://doi.org/10.1016/ j.tecto.2010.05.024

Enos, P., 1969, Cloridorme Formation, Middle Ordovician Flysch, Northern Gaspé Peninsula, Québec: Geological Society of America Special Papers, v. 117, p. 1-62, https://doi.org/10.1130/SPE117-p1

Foley, N. K., Clark, S. H. B., Woodruff, L. G., and Mosier, E. L., 1995, Geologic, geochemical, and isotopic studies of a carbonate-and siliciclastic-hosted $\mathrm{Pb}-\mathrm{Zn}$ deposit at Lion Hill, Vermont: US Geological Survey, Bulletin 2145, 31 p.

Ganis, G. R., 2005, Darriwilian graptolites of the Hamburg succession (Dauphin Formation), Pennsylvania, and their geologic significance: Canadian Journal of Earth Sciences, v. 42, n. 5, p. 791-813, https:// doi.org/10.1139/e05-010

Garver, J. I., Royce, P. R., and Smick, T. A., 1996, Chromium and nickel in shale of the Taconic foreland: a case study for the provenance of fine-grained sediments with an ultramafic source: Journal of Sedimentary Research, v. 66, n. 1, p. 100-106, https://doi.org/10.1306/D42682C5-2B26-11D7$8648000102 \mathrm{C} 1865 \mathrm{D}$

Gerstenberger, H., and Haase, G., 1997, A highly effective emitter substance for mass spectrometric $\mathrm{Pb}$ isotope ration determinations: Chemical Geology, v. 136, n. 3-4, p. 309-312, https://doi.org/10.1016/ S0009-2541(96) 00033-2

Goldman, D., Mitchell, C. E., Bergström, S. M., Delano, J. W., and Tice, S., 1994, K-bentonites and graptolite biostratigraphy in the Middle Ordovician of New York State and Québec: a new chronostratigraphic model: Palaios, v. 9, n. 2, p. 124-143, https://doi.org/10.2307/3515101

Goldstein, S. L., O'nions, R. K., and Hamilton, P. J., 1984, A Sm-Nd isotopic study of atmospheric dusts and particulates from major river systems: Earth and Planetary Science Letters, v. 70, n. 2, p. 221-236, https://doi.org/10.1016/0012-821X(84)90007-4 
Gradstein, F. M., Ogg, J. G., Schmitz, M., and Ogg, G., 2012, The Geologic Time Scale 2012, $1^{\text {st }}$ Edition, 2-volume set: Amsterdam, Elsevier, 1176 p.

Hibbard, J., and Karabinos, P., 2013, Disparate Paths in the Geologic Evolution of the Northern and Southern Appalachians: A Case for Inherited Contrasting Crustal/Lithospheric Substrates: Geoscience Canada, v. 40, p. 303-317, https://doi.org/10.12789/geocanj.2013.40.021

Hibbard, J., van Staal, C., Rankin, D., and Williams, H., 2006, Lithotectonic map of the Appalachian Orogen: Canada-United States of America: Geological Survey of Canada Map A, v. 2096, p. 2.

Hiscott, R. N., 1978, Provenance of Ordovician deep-water sandstones, Tourelle Formation, Québec, and implications for initiation of the Taconic orogeny: Canadian Journal of Earth Sciences, v. 15, n. 10, p. 1579-1597, https://doi.org/10.1139/e78-163

1984, Ophiolitic source rocks for Taconic-age flysch: Trace-element evidence: Geological Society of America Bulletin, v. 95, n. 11, p. 1261-1267, https://doi.org/10.1130/0016-7606(1984)95<1261: OSRFTF $>2.0 . \mathrm{CO} ; 2$

Hiscott, R., Pickering, K., and Beeden, D., 1986, Progressive Filling of a Confined Middle Ordovician Foreland Basin Associated with the Taconic Orogeny, Québec, Canada, in Allen, P. A., and Homewood, P., editors, Foreland Basins: Oxford, United Kingdom, Blackwell Publishing Ltd., p. 307-325, https:// doi.org/10.1002/9781444303810.ch17

Hodych, J. P., and Cox, R. A., 2007, Ediacaran U-Pb zircon dates for the Lac Matapédia and Mt. St.-Anselme basalts of the Québec Appalachians: support for a long-lived mantle plume during the rifting phase of Iapetus opening: Canadian Journal of Earth Sciences, v. 44, n. 4, p. 565-581, https://doi.org/10.1139/ e06-112

Hollocher, K., Robinson, P., Seaman, K., and Walsh, E., 2016, Ordovician-early Silurian intrusive rocks in the northwest part of the Upper Allochthon, mid-Norway: Plutons of an Iapetan volcanic arc complex: American Journal of Science, v. 316, n. 10, p. 925-980, https://doi.org/10.2475/10.2016.01

Howse, A. F., 2004, Industrial mineral potential of the Lower Paleozoic carbonate rocks of western Newfoundland.: Newfoundland and Labrador Department of Mines and Energy, Geological Survey, Open File NFLD/2853, p. 61.

Jacobi, L., ms, 1977, Stratigraphy, depositional environment, and structure of the Taconic Allochthon, Central Washington County, New York: Albany, New York, State University New York, Albany, MS thesis, $191 \mathrm{p}$.

Jacobi, R. D., 1981, Peripheral bulge-a causal mechanism for the Lower/Middle Ordovician unconformity along the western margin of the Northern Appalachians: Earth and Planetary Science Letters, v. 56, p. 245-251, https://doi.org/10.1016/0012-821X(81)90131-X

Jacobi, R. D., and Mitchell, C. E., 2002, Geodynamical interpretation of a major unconformity in the Taconic Foredeep: Slide scar or onlap unconformity?: Physics and Chemistry of the Earth, Parts A/B/C, v. 27, n. 1-3, p. 169-201, https://doi.org/10.1016/S1474-7065(01)00006-7

2016b, Ridge subduction incorporated into tectonic models of the Taconic Orogeny and its bearing on the Ordovician Utica Foreland Basin of New York State: Geological Society of America Abstracts with Programs, v. 48, n. 7, doi: 10.1130/abs/2016AM-280782, https://gsa.confex.com/gsa/2016AM/ webprogram/Paper280782.html

- 2017, Ridge subduction incorporated into tectonic models of the Taconic Orogeny in Southern New England and New York State and its bearing on the Ordovician Utica Foreland Basin: Geological Society of America Abstracts with Programs, v. 49, n. 2, paper n. 13-7, doi:10.1130/abs/2017NE-291072 https://gsa.confex.com/gsa/2017NE/webprogram/Paper291072.html

Jacobi, R. D., Mitchell, C. E., and Kidd, W. S. F., 2016a, Albany nappes (not our elected officials), Argentina, and plate tectonic models: implications from seismic and outcrop data in the Ordovician foreland basin of NYS: Geological Society of America Abstracts with Programs, v. 48, n. 2, paper n. 30-4 doi: 10.1130/abs/2016NE-272786, https://gsa.confex.com/gsa/2016NE/webprogram/Paper272786.html

Jaffey, A. H., Flynn, K. F., Glendenin, L. E., Bentley, W. C., and Essling, A. M., 1971, Precision measurements of half-lives and specific activities of ${ }^{235} \mathrm{U}$ and ${ }^{238} \mathrm{U}$ : Physical Review C, v. 4, n. 5, p. 1889-1906, https://doi.org/10.1103/PhysRevC.4.1889

James, N. P., and Stevens, R. K., 1986, Stratigraphy and correlation of the Cambro-Ordovician Cow Head Group, western Newfoundland: Geological Survey of Canada, Bulletin, v. 366, 143 p., 4 sheets, https://doi.org/10.4095/125053

Jenner, G., Dunning, G., Malpas, J., Brown, M., and Brace, T., 1991, Bay of Islands and Little Port complexes, revisited: age, geochemical and isotopic evidence confirm suprasubduction-zone origin: Canadian Journal of Earth Sciences, v. 28, n. 10, p. 1635-1652, https://doi.org/10.1139/e91-146

Johnson, R. J. E., van der Pluijm, B. A., and Van der Voo, R., 1991, Paleomagnetism of the Moreton's Harbour Group, northeastern Newfoundland Appalachians: Evidence for an Early Ordovician island arc near the Laurentian margin of Iapetus: Journal of Geophysical Research: Solid Earth, v. 96, n. B7, p. 11689-11701, https://doi.org/10.1029/91JB00870

Kamo, S. L., Gower, C. F., and Krogh, T. E., 1989, Birthdate for the lapetus Ocean? A precise U-Pb zircon and baddeleyite age for the Long Range dikes, southeast Labrador: Geology, v. 17, n. 7, p. 602-605, https:/ /doi.org/10.1130/0091-7613(1989)017<0602:BFTLOA > 2.3.CO;2

Karabinos, P., 1988, Tectonic significance of basement-cover relationships in the Green Mountain massif, Vermont: The Journal of Geology, v. 96, n. 4, p. 445-454, https://doi.org/10.1086/629239

Karabinos, P. A., and Aleinikoff, J. N., 1990, Evidence for a major middle Proterozoic, post-Grenvillian igneous event in western New England: American Journal of Science, v. 290, n. 8, p. 959-974, https://doi.org/10.2475/ajs.290.8.959

Karabinos, P., Samson, S. D., Hepburn, J. C., and Stoll, H. M., 1998, Taconian orogeny in the New England Appalachians: collision between Laurentia and the Shelburne Falls arc: Geology, v. 26, n. 3, p. 215-218, https://doi.org/10.1130/0091-7613(1998)026<0215:TOITNE>2.3.CO;2 
Karabinos, P., Morris, D., Hamilton, M., and Rayner, N., 2008, Age, origin, and tectonic significance of Mesoproterozoic and Silurian felsic sills in the Berkshire massif, Massachusetts: American Journal of Science, v. 308, n. 6, p. 787-812, https://doi.org/10.2475/06.2008.03

Karabinos, P., Macdonald, F. A., and Crowley, J. L., 2017, Bridging the gap between the foreland and the hinterland: Geochronology and tectonic setting of the hinterland of New England: American Journal of Science, v. 317, n. 5, p. XXX-XXX, https://doi.org/10.2475/05.2017.01

Knight, I., and James, N. P., 1987, The stratigraphy of the Lower Ordovician St. George Group, western Newfoundland: The interaction between eustasy and tectonics: Canadian Journal of Earth Sciences, v. 24, n. 10, p. 1927-1951, https://doi.org/10.1139/e87-185

Knight, I., James, N. P., and Lane, T. E., 1991, The Ordovician St. George Unconformity, northern Appalachians: The relationship of plate convergence at the St. Lawrence Promontory to the Sauk/ Tippecanoe sequence boundary: Geological Society of America Bulletin, v. 103, n. 9, p. 1200-1225, http:/ /dx.doi.org/10.1130/0016-7606(1991) 103<1200:TOSGUN>2.3.CO;2

Kolata, D. R., Huff, W. D., and Bergstrom, S. M., 1996, Ordovician K-bentonites of eastern North America: Geological Society of America Special Papers, v. 313, p. 1-89, https://doi.org/10.1130/0-8137-2313-2.1

Krough, T.E., 1973, A low contamination method for hydrothermal decompostion of zircon and extraction of $\mathrm{U}$ and $\mathrm{Pb}$ for isotopic age determination: Geochmica et Cosmochimica Acta, v. 37, n. 3, p. 485-494, https://doi.org/10.1016/0016-7037(73)90213-5

Kumarapeli, P. S., Dunning, G. R., Pintson, H., and Shaver, J., 1989, Geochemistry and U-Pb zircon age of comenditic metafelsites of the Tibbit Hill Formation, Québec Appalachians: Canadian Journal of Earth Sciences, v. 26, n. 7, p. 1374-1383, https://doi.org/10.1139/e89-117

Kyle, J., 1976, Brecciation, alteration and mineralization in the Central Tennessee zinc district: Economic Geology, v. 71, n. 5, p. 892-903, https://doi.org/10.2113/gsecongeo.71.5.892

Laird, J., Lanphere, M. A., and Albee, A. L., 1984, Distribution of Ordovician and Devonian metamorphism in mafic and pelitic schists from northern Vermont: American Journal of Science, v. 284, n. 5, p. 376-413, https://doi.org/10.2475/ajs.284.4-5.376

Landing, E., 2012, The great American carbonate bank in eastern Laurentia: Its births, deaths, and linkage to paleooceanic oxygenation (Early Cambrian-Late Ordovician), in Derby, J. R., Fritz, R. D., Longacre, S. A., Morgan, W. A.,and Sternbach, C. A., editors, The great American carbonate bank: The geology and economic resources of the Cambrian - Ordovician Sauk megasequence of Laurentia: AAPG Memoir 98, p. 451-492, https://doi.org/10.1306/13331502M983502

Landing, E., Pe-Piper, G., Kidd, W. S. F., and Azmy, K., 2003, Tectonic setting of outer trench slope volcanism: pilow basalt and limestone in the Taconian orogen of eastern New York: Canadian Journal of Earth Sciences, v. 40, n. 12, p. 1773-1787, https://doi.org/10.1139/e03-076

Landing, E., Westrop, S. R., and van Aller Hernick, L., 2003, Uppermost Cambrian-lower Ordovician faunas and Laurentian platform sequence stratigraphy, eastern New York and Vermont: Journal of Paleontology, v. 77, n. 1, p. 78-98, https://doi.org/10.1017/S0022336000043444

Lash, G. G., 1986, Sedimentological and geochemical evidence for Middle Ordovician near-trench volcanism in the central Appalachian orogen: The Journal of Geology, v. 94, n. 1, p. 91-107, https://doi.org/ $10.1086 / 629011$

Lash, G. G., and Drake, A. A., 1984, The Richmond and Greenwich slices of the Hamburg klippe in eastern Pennsylvania: Stratigraphy, sedimentology, structure, and plate tectonic implications: USGS Professional Paper 1312, 40 p.

Lavoie, D., 1994, Diachronous tectonic collapse of the Ordovician continental margin, eastern Canada: comparison between the Québec Reentrant and St. Lawrence Promontory: Canadian Journal of Earth Sciences, v. 31, n. 8, p. 1309-1319, https://doi.org/10.1139/e94-113

Lavoie, D., Burden, E., and Lebel, D., 2003, Stratigraphic framework for the Cambrian Ordovician rift and passive margin successions from southern Québec to western Newfoundland: Canadian Journal of Earth Sciences, v. 40, n. 2, p. 177-205, https://doi.org/10.1139/e02-078

Lehmann, D., Brett, C. E., Cole, R., and Baird, G., 1995, Distal sedimentation in a peripheral foreland basin: Ordovician black shales and associated flysch of the western Taconic foreland, New York State and Ontario: Geological Society of America Bulletin, v. 107, n. 6, p. 708-724, https://doi.org/10.1130/00167606(1995) $107<0708$ :DSIAPF $>2.3 . \mathrm{CO} ; 2$

Ludwig, K. R., 2003, User's manual for Isoplot 3.00: A geochronological toolkit for Microsoft Excel: Berkeley, California, Berkeley Geochronology Center Special Publication, v. 4, p. 1-70.

Macdonald, F. A., Ryan-Davis, J., Coish, R. A., Crowley, J. L., and Karabinos, P., 2014, A newly identified Gondwanan terrane in the northern Appalachian Mountains: Implications for the Taconic orogeny and closure of the Iapetus Ocean: Geology, v. 42, n. 6, p. 539-542, https://doi.org/10.1130/G35659.1

Mattinson, J. M., 2005, Zircon U-Pb chemical abrasion ("CA-TIMS") method: combined annealing and multi-step partial dissolution analysis for improved precision and accuracy of zircon ages: Chemical Geology, v. 220, n. 1-2, p. 47-66, https://doi.org/10.1016/j.chemgeo.2005.03.011

McDaniel, D. K., Hemming, S. R., McLennan, S. M., and Hanson, G. N., 1994, Resetting of neodymium isotopes and redistribution of REEs during sedimentary processes: the Early Proterozoic Chelmsford Formation, Sudbury Basin, Ontario, Canada: Geochimica et Cosmochimica Acta, v. 58, n. 2, p. 931-941, https://doi.org/10.1016/0016-7037(94)90516-9

McKenzie, D., 1978, Some remarks on the development of sedimentary basins: Earth and Planetary Science Letters, v. 40, n. 1, p. 25-32, https://doi.org/10.1016/0012-821X(78)90071-7

McLennan, S. M., 1989, Rare earth elements in sedimentary rocks: influence of provenance and sedimentary processes, in Lipin, B. R., and McKay, G. A., editors, Geochemistry and Mineraology of Rare Earth Elements: Reviews in Mineralogy and Geochemistry, v. 21, p. 169-200.

McLennan, S. M., Hemming, S., McDaniel, D. K., and Hanson, G. N., 1993, Geochemical approaches to 
sedimentation, provenance, and tectonics: Geological Society of America Special Papers, v. 284, p. 21-40, https://doi.org/10.1130/spe284-p21

Mehrtens, C., and Hadley, A. C., 1995, Stratigraphy and Bedrock Geology of Parts of the St. Albans and Georgia Quadrangles, Northwestern Vermont: Vermont Geological Survey, Special Bulletin, n. 14, 21 p.

Metzger, J. G., Fike, D. A., and Smith, L. B., 2014, Applying carbon-isotope stratigraphy using well cuttings for high-resolution chemostratigraphic correlation of the subsurface: AAPG Bulletin, v. 98, p. 1551-1576, https://doi.org/10.1306/04011412231

Meyers, S. R., and Peters, S. E., 2011, A 56 million year rhythm in North American sedimentation during the Phanerozoic: Earth and Planetary Science Letters, v. 303, n. 3-4, p. 174-180, https://doi.org/10.1016/ j.epsl.2010.12.044

Mitchell, C. E., Goldman, D., Delano, J. W., Samson, S. D., and Bergström, S. M., 1994, Temporal and spatial distribution of biozones and facies relative to geochemically correlated K-bentonites in the Middle Ordovician Taconic foredeep: Geology, v. 22, n. 8, p. 715-718, https://doi.org/10.1130/00917613(1994)022<0715:TASDOB > 2.3.CO;2

Mitrovica, J. X., Beaumont, C., and Jarvis, G. T., 1989, Tilting of continental interiors by the dynamical effects of subduction: Tectonics, v. 8, n. 5, p. 1079-1094. https://doi.org/10.1029/TC008i005p01079

Moench, R. H., and Aleinikoff, J. N., 2003, Stratigraphy, geochronology, and accretionary terrane settings of two Bronson Hill arc sequences, northern New England: Physics and Chemistry of the Earth, Parts A/B/C, v. 28, n. 1-3, p. 113-160, https://doi.org/10.1016/S1474-7065(03)00012-3

Mussman, W., and Read, J., 1986, Sedimentology and development of a passive-to convergent-margin unconformity: Middle Ordovician Knox unconformity, Virginia Appalachians: Geological Society of America Bulletin, v. 97, n. 3, p. 282-295, https://doi.org/10.1130/0016-7606(1986) 97<282: $\mathrm{SADOAP}>2.0 . \mathrm{CO} ; 2$

Naylor, M., and Sinclair, H. D., 2008, Pro-vs. retro-foreland basins: Basin Research, v. 20, n. 3, p. 285-303, https://doi.org/10.1111/j.1365-2117.2008.00366.x

Peters, S. E., 2006, Macrostratigraphy of North America: The Journal of Geology, v. 114, n. 4, p. 391-412, https://doi.org/10.1086/504176

Potts, S. S., van der Pluijm, B. A., and Van der Voo, R., 1993, Paleomagnetism of the Ordovician Bluffer Pond Formation: Paleogeographic implications for the Munsungun terrane of northern Maine: Journal of Geophysical Research: Solid Earth, v. 98, n. B5, p. 7987-7996, https://doi.org/10.1029/93JB00017

Potts, S. S., van der Pluijm, B. A., and Van der Voo, R., 1995, Paleomagnetism of the Pennington Mountain terrane: A near-Laurentian back arc basin in the Maine Appalachians: Journal of Geophysical ResearchSolid Earth, v. 100, n. B6, p. 10,003-10,011, https://doi.org/10.1029/94JB03013

Pratt, B. R., and James, N. P., 1986, The St George Group (Lower Ordovician) of western Newfoundland: Tidal flat island model for carbonate sedimentation in shallow epeiric seas: Sedimentology, v. 33, n. 3, p. 313-343, https://doi.org/10.1111/j.1365-3091.1986.tb00540.x

Quinlan, G. M., and Beaumont, C., 1984, Appalachian thrusting, lithospheric flexure, and the Paleozoic stratigraphy of the eastern interior of North America: Canadian Journal of Earth Sciences, v. 21, n. 9, p. 973-996, https://doi.org/10.1139/e84-103

Quinn, L., Harper, D. A. T., Williams, S. H., and Clarkson, E. N. K., 1999, Late Ordovician foreland basin fill: Long Point Group of onshore western Newfoundland: Bulletin of Canadian Petroleum Geology, v. 47, n. 1, p. 63-80.

Raczek, I., Jochum, K. P., and Hofmann, A. W., 2003, Neodymium and strontium isotope data for USGS reference materials BCR-1, BCR-2, BHVO-1, BHVO-2, AGV-1, AGV-2, GSP-1, GSP-2 and eight MPIDING reference glasses: Geostandards Newsletter, v. 27, n. 2, p. 173-179, https://doi.org/10.1111/j.1751908X.2003.tb00644.x

Rankin, D. W., Tucker, R. D., and Amelin, Y., 2013, Reevaluation of the Piermont-Frontenac allochthon in the Upper Connecticut Valley: Restoration of a coherent Boundary Mountains-Bronson Hill stratigraphic sequence: Geological Society of America Bulletin, v. 125, n. 5-6, p. 998-1024, https://doi.org/ $10.1130 /$ B30590.1

Ratcliffe, N. M., Aleinikoff, J. N., Burton, W. C., and Karabinos, P., 1991, Trondhjemitic, 1.35-1.31 Ga gneisses of the Mount Holly Complex of Vermont: evidence for an Elzevirian event in the Grenville Basement of the United States Appalachians: Canadian Journal of Earth Sciences, v. 28, n. 1, p. 77-93, https://doi.org/10.1139/e91-007

Ratcliffe, N. M., Harris, A. G., and Walsh, G. J., 1999, Tectonic and regional metamorphic implications of the discovery of Middle Ordovician conodonts in cover rocks east of the Green Mountain massif, Vermont: Canadian Journal of Earth Sciences, v. 36, n. 3, p. 371-382, https://doi.org/10.1139/e99-009

Ratcliffe, N. M., Stanley, R. S., Gale, M. H., Thompson, P. J., and Walsh, G., 2011, Bedrock geologic map of Vermont, scale 1:100,000.

Riva, J., 1974, A revision of some Ordovician graptolites of eastern North America: Palaeontology, v. 17, p. $1-40$.

Rivers, T., 1997, Lithotectonic elements of the Grenville Province: Review and tectonic implications: Precambrian Research, v. 86, n. 3-4, p. 117-154, https://doi.org/10.1016/S0301-9268(97)00038-7

Rowley, D. B., 2002, Rate of plate creation and destruction: 180 Ma to present: Geological Society of America Bulletin, v. 114, n. 7, p. 927-933, https://doi.org/10.1130/0016-7606(2002) 114<0927: ROPCAD $>2.0 . \mathrm{CO} ; 2$

Rowley, D. B., and Kidd, W. S. F., 1981, Stratigraphic relationships and detrital composition of the medial Ordovician flysch of western New England: Implications for the tectonic evolution of the Taconic orogeny: The Journal of Geology, v. 89, n. 2, p. 199-218, https://doi.org/10.1086/628580

Rowley, D. B., Kidd, W. S. F., and Delano, L. L., 1979, Detailed stratigraphic and structural features of the Giddings Brook slice of the Taconic Allochthon in the Granville area: New York State Geological Association and NEIGC Guidebook, p. 186-242. 
Ryan, P. C., Coish, R., and Joseph, K., 2007, Ordovician K-bentonites in western Vermont: Mineralogic, stratigraphic, and geochemical evidence for their occurrence and tectonic significance: Geological Society of America Abstracts with Programs, p. 50.

Schmitz, M. D., and Schoene, B., 2007, Derivation of isotope ratios, errors and error correlations for U-Pb geochronology using ${ }^{205} \mathrm{~Pb}^{-235} \mathrm{U}-\left({ }^{233} \mathrm{U}\right)$-spiked isotope dilution thermal ionization mass spectrometric data: Geochemistry, Geophysics, Geosystems, v. 8, n. 8, p. Q08006, https://doi.org/10.1029/ 2006GC001492

Schroetter, J.-M., Tremblay, A., Bédard, J. H., and Villeneuve, M. E., 2006, Syncollisional basin development in the Appalachian orogen-the Saint-Daniel Mélange, southern Québec, Canada: Geological Society of America Bulletin, v. 118, n. 1-2, p. 109-125, https://doi.org/10.1130/B25779.1

Sell, B., Leslie, S., and Maletz, J., 2011, New U-Pb zircon data for the GSSP for the base of the Katian in Atoka Oklahoma, USA, and the Darriwilian in Newfoundland, Canada: Ordovician of the World: Madrid, Instituto Geológico y Minero de España, Caudernos del Museo Geominero, v. 14, p. 537-546.

Sell, B., Ainsaar, L., and Leslie, S., 2013, Precise timing of the Late Ordovician (Sandbian) super-eruptions and associated environmental, biological, and climatological events: Journal of the Geological Society, v. 170, p. 711-714, https://doi.org/10.1144/jgs2012-148

Sell, B. K., Samson, S. D., Mitchell, C. E., McLaughlin, P. I., Koenig, A. E., and Leslie, S. A., 2015, Stratigraphic correlations using trace elements in apatite from Late Ordovician (Sandbian-Katian) K-bentonites of eastern North America: Geological Society of America Bulletin, v. 127, n. 9-10, p. 1259-1274, https://doi.org/10.1130/B31194.1

Settle, M., 1978, Volcanic eruption clouds and the thermal power output of explosive eruptions: Journal of Volcanology and Geothermal Research, v. 3, n. 3-4, p. 309-324, https://doi.org/10.1016/03770273(78)90041-0

Sevigny, J. H., and Hanson, G. N., 1993, Orogenic evolution of the New England Appalachians of southwestern Connecticut: Geological Society of America Bulletin, v. 105, n. 12, p. 1591-1605, https://doi.org/10.1130/0016-7606(1993)105<1591:OEOTNE > 2.3.CO;2

_ 1995, Late-Taconian and pre-Acadian history of the New England Appalachians of southwestern Connecticut: Geological Society of America Bulletin, v. 107, n. 4, p. 487-498, https://doi.org/10.1130/ 0016-7606 (1995) 107<0487:LTAPAH>2.3.CO;2

Shanmugam, G., and Lash, G. G., 1982, Analogous tectonic evolution of the Ordovician foredeeps, southern and central Appalachians: Geology, v. 10, n. 11, p. 562-566, https://doi.org/10.1130/00917613(1982) $10<562:$ ATEOTO > 2.0.CO;2

Sigurdsson, H., Sparks, R. S. J., Carey, S. N., and Huang, T. C., 1980, Volcanogenic sedimentation in the Lesser Antilles arc: The Journal of Geology, v. 88, n. 5, p. 523-540, https://doi.org/10.1086/628542

Sinclair, H. D., and Naylor, M., 2012, Foreland basin subsidence driven by topographic growth versus plate subduction: Geological Society of America Bulletin, v. 124, n. 3-4, p. 368-379, https://doi.org/10.1130/ B30383.1

Sláma, J., Košler, J., Condon, D. J., Crowley, J. L., Gerdes, A., Hanchar, J. M., Horstwood, M. S., Morris, G. A., Nasdala, L., and Norberg, N., 2008, Plešovice zircon-a new natural reference material for U-Pb and Hf isotopic microanalysis: Chemical Geology, v. 249, n. 1-2, p. 1-35, https://doi.org/10.1016/ j.chemgeo.2007.11.005

Sloss, L., 1963, Sequences in the cratonic interior of North America: Geological Society of America Bulletin, v. 74, n. 2, p. 93-114, https://doi.org/10.1130/0016-7606(1963)74[93:SITCIO]2.0.CO;2

Smith, M. E., Singer, B. S., and Simo, T., 2011, A time like our own? Radioisotopic calibration of the Ordovician greenhouse to icehouse transition: Earth and Planetary Science Letters, v. 311, n. 3-4, p. 364-374, https://doi.org/10.1016/j.epsl.2011.09.014

Stanley, R. S., and Ratcliffe, N. M., 1985, Tectonic synthesis of the Taconian orogeny in western New England: Geological Society of America Bulletin, v. 96, n. 10, p. 1227-1250, https://doi.org/10.1130/ 0016-7606(1985) 96<1227:TSOTTO>2.0.CO;2

Stenzel, S. R., Knight, I., and James, N. P., 1990, Carbonate platform to foreland basin: revised stratigraphy of the Table Head Group (Middle Ordovician), western Newfoundland: Canadian Journal of Earth Sciences, v. 27, n. 1, p. 14-26, https://doi.org/10.1139/e90-002

Stevens, R., 1970, Cambro-Ordovician flysch sedimentation and tectonics in west Newfoundland and their possible bearing on a Proto-Atlantic Ocean, in Lajoie, J., editor, Flysch Sedimentology in North America: Geological Association of Canada Special Paper n. 7, p. 165-177.

Suhr, G., and Cawood, P. A., 1993, Structural history of ophiolite obduction, Bay of Islands, Newfoundland: Geological Society of America Bulletin, v. 105, n. 3, p. 399-410, https://doi.org/10.1130/00167606(1993) $105<0399: \mathrm{SHOOOB}>2.3 . \mathrm{CO} ; 2$

Tanaka, T., Togashi, S., Kamioka, H., Amakawa, H., Kagami, H., Hamamoto, T., Yuhara, M., Orihashi, Y., Yoneda, S., and Shimizu, H., 2000, JNdi-1: a neodymium isotopic reference in consistency with LaJolla neodymium: Chemical Geology, v. 168, n. 3-4, p. 279-281, https://doi.org/10.1016/S00092541(00)00198-4

Theokritoff, G., 1964, Taconic stratigraphy in northern Washington county, New York: Geological Society of America Bulletin, v. 75, n. 3, p. 171-190, https://doi.org/10.1130/0016-7606(1964)75[171: TSINWC]2.0.CO;2

Theokritoff, G., and Thompson, J. B., Jr., 1969, Field Trip 7: Stratigraphy of the Champlain Valley Sequence in Rutland County, Vermont, and the Taconic Sequence in Northern Washington County, New York: New England Intercollegiate Geological Conference, Guidebook for Field Trips in New York, Massachusetts, and Vermont, p. 7-1-7-26.

Torsvik, T. H., van der Voo, R., Doubrovine, P. V., Burke, K., Steinberger, B., Ashwal, L. D., Trønnes, R. G., Webb, S. J., and Bull, A. L., 2014, Deep mantle structure as a reference frame for movements in and on 
the Earth: Proceedings of the National Academy of Sciences, v. 111, n. 24, p. 8735-8740, https://doi.org/ $10.1073 /$ pnas. 1318135111

Tremblay, A., and Pinet, N., 2016, Late Neoproterozoic to Permian tectonic evolution of the Québec Appalachians, Canada: Earth Science Reviews, v. 160, p. 131-170, https://doi.org/10.1016/ j.earscirev.2016.06.015

Tremblay, A., Ruffet, G., and Bédard, J. H., 2011, Obduction of Tethyan-type ophiolites-A case-study from the Thetford-Mines ophiolitic Complex, Québec Appalachians, Canada: Lithos, v. 125, n. 1-2, p. 10-26, https://doi.org/10.1016/j.lithos.2011.01.003

Tucker, R. D., and Robinson, P., 1990, Age and setting of the Bronson Hill magmatic arc: A re-evaluation based on U-Pb zircon ages in southern New England: Geological Society of America Bulletin, v. 102, n. 10, p. 1404-1419, https://doi.org/10.1130/0016-7606(1990) 102<1404:AASOTB > 2.3.CO;2

Tucker, R. D., Krogh, T. E., Ross, R. J., and Williams, S. H., 1990, Time-scale calibration by high-precision $\mathrm{U}-\mathrm{Pb}$ zircon dating of interstratified volcanic ashes in the Ordovician and Lower Silurian stratotypes of Britain: Earth and Planetary Science Letters, v. 100, n. 1-3, p. 51-58, https://doi.org/10.1016/0012821X(90)90175-W

van Staal, C., and Barr, S., 2012, Lithospheric architecture and tectonic evolution of the Canadian Appalachians and associated Atlantic margin, in Percival, J. A., Cook, F. A., and Clowes, R. M., editors Tectonic styles in Canada revisted: The LITHOPROBE perspective: Geological Association of Canada Special Paper, v. 49, p. 55.

van Staal, C. R., Dewey, J. F., Mac Niocaill, C., and McKerrow, W. S., 1998, The Cambrian-Silurian tectonic evolution of the northern Appalachians and British Caledonides: History of a complex, west and southwest Pacific-type segment of Iapetus: Geological Society, London, Special Publications, v. 143, p. 197-242, https://doi.org/10.1144/GSL.SP.1998.143.01.17

van Staal, C., Whalen, J., McNicoll, V., Pehrsson, S., Lissenberg, C. J., Zagorevski, A., van Breemen, O., and Jenner, G., 2007, The Notre Dame arc and the Taconic orogeny in Newfoundland: Geological Society of America Memoirs, v. 200, p. 511-552.

van Staal, C. R., Chew, D. M., Zagorevski, A., McNicoll, V., Hibbard, J., Skulski, T., Escayola, M. P., Castonguay, S., and Sylvester, P. J., 2013, Evidence of Late Ediacaran hyperextension of the Laurentian Iapetan margin in the Birchy Complex, Baie Verte Peninsula, northwest Newfoundland: implications for the opening of Iapetus, formation of peri-Laurentian microcontinents and Taconic-Grampian orogenesis: Geoscience Canada, v. 40, n. 2, p. 94-117, https://doi.org/10.12789/geocanj.2013.40.006

van Staal, C., Wilson, R., Kamo, S., McClelland, W., and McNicoll, V., 2016, Evolution of the Early to Middle Ordovician Popelogan arc in New Brunswick, Canada, and adjacent Maine, USA: Record of arc-trench migration and multiple phases of rifting: Geological Society of America Bulletin, v. 128, n. 1-2, p. 122-146, https://doi.org/10.1130/B31253.1

Waldron, J. W., and van Staal, C. R., 2001, Taconian orogeny and the accretion of the Dashwoods block: A peri-Laurentian microcontinent in the Iapetus Ocean: Geology, v. 29, n. 9, p. 811-814, https://doi.org/ 10.1130/0091-7613(2001)029<0811:TOATAO >2.0.CO;2

Walsh, G. J., and Aleinikoff, J. N., 1999, U-Pb zircon age of metafelsite from the Pinney Hollow Formation; implications for the development of the Vermont Appalachians: American Journal of Science, v. 299, n. 2, p. 157-170, https://doi.org/10.2475/ajs.299.2.157

Walsh, G. J., Aleinikoff, J. N., and Fanning, C. M., 2004, U-Pb geochronology and evolution of Mesoproterozoic basement rocks, western Connecticut: Geological Society of America Memoirs, v. 197, p. 729-753, https://doi.org/10.1130/0-8137-1197-5.729

Washington, P. A., and Chisick, S. A., 1994, Foundering of the Cambro-Ordovician shelf margin: onset of Taconian orogenesis or eustatic drowning: Tectonic and Eustatic Controls on Sedimentary Cycles: SEPM Concepts in Sedimentology and Paleontology, v. 4, p. 203-216, https://doi.org/10.2110/csp.94.04.0203

Watson, E. B., Wark, D. A., and Thomas, J. B., 2006, Crystallization thermometers for zircon and rutile: Contributions to Mineralogy and Petrology, v. 151, p. 413-433, https://doi.org/10.1007/s00410-0060068-5

Wellensiek, M. R., van der Pluijm, B. A., Van der Voo, R., and Johnson, R. J., 1990, Tectonic history of the Lunksoos composite terrane in the Maine Appalachians: Tectonics, v. 9, n. 4, p. 719-734, https://doi.org/ 10.1029/TC009i004p00719

Whitehead, J., Reynolds, P. H., and Spray, J. G., 1996, ${ }^{40} \mathrm{Ar} /{ }^{39} \mathrm{Ar}$ age constraints on Taconian and Acadian events in the Québec Appalachians: Geology, v. 24, p. 359-362.

Whitehead, J., Dunning, G. R., and Spray, J. G., 2000, U-Pb geochronology and origin of granitoid rocks in the Thetford Mines ophiolite, Canadian Appalachians: Geological Society of America Bulletin, v. 112, n. 6, p. 915-928, https://doi.org/10.1130/0016-7606(2000) 112<915:UGAOOG $>2.0$.CO;2

Williams, H., 1979, Appalachian orogen in Canada: Canadian Journal of Earth Sciences, v. 16, n. 3, p. 792-807, https://doi.org/10.1139/e79-070

Winchester, J. A., and Floyd, P. A., 1977, Geochemical discrimination of different magma series and their differentiation products using immobile elements: Chemical Geology, v. 20, p. 325-343, https://doi.org/ 10.1016/0009-2541(77)90057-2

Young, F. P., Jr., 1943, Black River stratigraphy and faunas, Part 1: American Journal of Science, v. 241, n. 3, p. 141-166, https://doi.org/10.2475/ajs.241.3.141

Zagorevski, A., and van Staal, C. R., 2014, Discussion on 'The sole of an ophiolite: the Ordovician Bay of Islands Complex, Newfoundland'Journal, 170, 2013, p. 715-722: Journal of the Geological Society, v. 172, n. 4, p. 519-521, https://doi.org/10.1144/jgs2013-128

Zen, E.-A., 1967, Time and space relationships of the Taconic allochthon and autochthon: Geological Society of America Special Papers, v. 97, p. 1-82, https://doi.org/10.1130/SPE97-p1

1983, Exotic terranes in the New England Appalachians-limits, candidates, and ages: a speculative essay: Geological Society of America Memoirs, v. 158, p. 55-82, https://doi.org/10.1130/MEM158-p55 